University of Rhode Island

DigitalCommons@URI

Open Access Master's Theses

1978

\title{
Flux and Processes of Deposition of Atmospheric Sea Salt to the Earth Surface
}

Azhari F. M. Ahmed

University of Rhode Island

Follow this and additional works at: https://digitalcommons.uri.edu/theses

\section{Recommended Citation}

Ahmed, Azhari F. M., "Flux and Processes of Deposition of Atmospheric Sea Salt to the Earth Surface" (1978). Open Access Master's Theses. Paper 968.

https://digitalcommons.uri.edu/theses/968

This Thesis is brought to you for free and open access by DigitalCommons@URI. It has been accepted for inclusion in Open Access Master's Theses by an authorized administrator of DigitalCommons@URI. For more information, please contact digitalcommons-group@uri.edu. 
FLUX AND PROCESSES OF DEPOSITION OF

ATMOSPHERIC SEA SALT TO THE EARTH SURFACE

BY

AZHARI F. M. AHMED

A THESIS SUBMITTED IN PARTIAL FULFILLMENT OF THE REQUIREMENTS FOR THE DEGREE OF

MASTER OF SCIENCE

IN

OCEANOGRAPHY

UNIVERSITY OF RHODE ISLAND

1978 


\section{MASTER OF SCIENCE THESIS}

OF

\section{AZHARI F. M. AHMED}

Approved:

Thes is Cornmittee

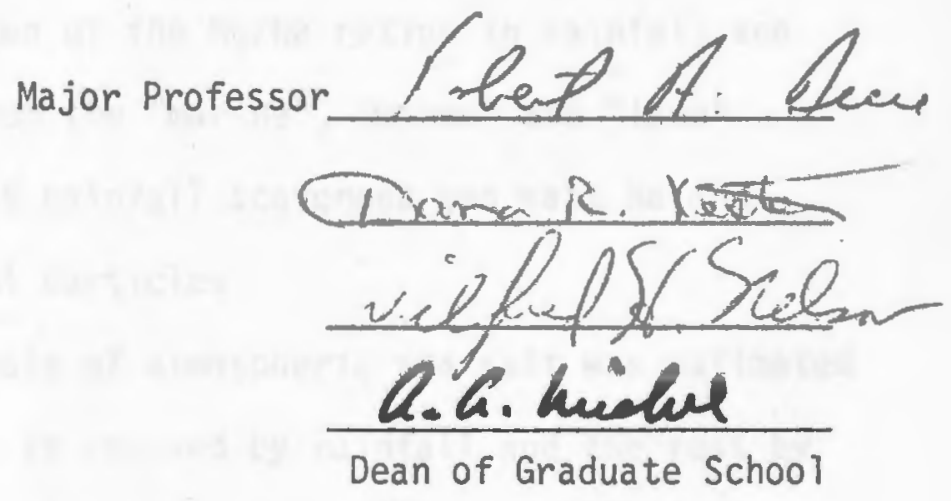

UNIVERSITY OF RHODE ISLAND 


\section{ABSTRACT}

Dry deposition, rainfall and atmospheric particulate samples collected at a coastal Rhode Island site, and aboard RV/Trident over the North West Atlantic Ocean were analysed for $\mathrm{Na}$ and $\mathrm{Mg}$ in order to understand the rate and mechanisms of removal of atmospheric sea salt. Perkin Elmer atomic absorption spectrophotometer models 303 and 360 were used for the analyses. Samples collected at the R.I. coastal site were divided into 3 different categories, namely, "marine", "land" and "mixed" samples depending on the local surface wind direction during sampling. Based upon the $\mathrm{Mg} / \mathrm{Na}$ ratic, it appears that most of the $\mathrm{Na}$ and $\mathrm{Mg}$ in "marine" samples were derived from the ocean while "land" samples essentially consist of $\mathrm{Na}$ and $\mathrm{Mg}$ of crustal origin and "mixed" samples were a combination of the two.

The rate of wet removal of atmospheric $\mathrm{Na}$ and $\mathrm{Mg}$, calculated from "marine" and "land" samples and the rate of dry depositicr. of sea. salt calculated only from "marine" samples, appear to be proportional to the wind speed. Consideration of the $\mathrm{Mg} / \mathrm{Na}$ ratios in rainfall and dry fallout samples observed from the "marine", "mixed" and "land" samples categories, suggest that rainfall scavenges sea salt $\mathrm{Na}$ and Mg more efficiently than crustal particles.

The annual global removal rate of atmospheric sea salt was estimated at $23.0 \times 10^{15} \mathrm{~g} / \mathrm{yr} .60 \%$ of this is removed by rainfall and the rest by dry deposition. Of the total cyclic sea salt removed annually over the globe, less than $7 \%$ is deposited over land. $90 \%$ of this is removed by rainfall and the rest by dry deposition. 
I am most grateful to my major professor Dr. Robert A. Duce for his valuable help and guidance during my graduate work. I not only thank him for stimulating my interest in the field of marine atmospheric chemistry and his open-door policy, but most of all for his deep understanding, patience and compassion throughout my stay at the Graduate School of Oceanography.

I wish to give special thanks to Dr. Stephen R. Piotrowicz, Dr. Gerald L. Hoffman, Ms. Barbra Ray, Dr. Eva J. Hoffman and Mr. Clifford Weisel for their help and suggestions.

Thanks are also due to the AMIDEAST and the National Council for Research of Sudan for providing the scholarship and financial support for this investigation.

I also acknowledge the support of the National Science Foundation through NSF grants OCE76-16883 and GX-33777.

Grateful appreciation is extended to Mrs. Pat Aldrich for typing this dissertation.

This thesis is dedicated to my parents who encouraged and supported me faithfully throughout my education. 


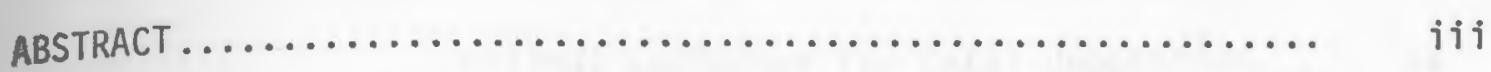

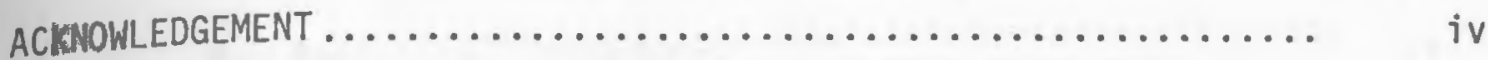

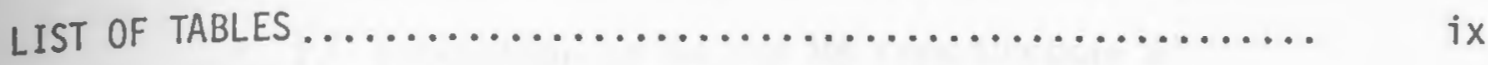

LIST OF FIGURES $\ldots \ldots \ldots \ldots \ldots \ldots \ldots \ldots \ldots \ldots \ldots \ldots \ldots \ldots \ldots \ldots \ldots \ldots \ldots \ldots \ldots \ldots \ldots$

CHAPTER I. INTRODUCTION......................... 1

A. Removal Mechanisms of Atmospheric Sea Salt......

B. Review of the History of Sea Salt in Rainwater... 3

C. Mechanisms of Production of Atmospheric Sea Salt. 7 Particles

D. Geochemical Cycle of Atmospheric Sea Salt....... 8

E. Reseàrch Objectives ................... 11

CHAPTER II. EXPERIMENTAL METHODS $\ldots \ldots \ldots \ldots \ldots \ldots \ldots \ldots \ldots \ldots \ldots$

A. Sampling Procedures.................... 13

1. General Considerations ............... 13

2. The Automatic Rain-Dry Fallout Collector..... 14

3. Sample Handling................... 16

4. Testing Programs for the Sampling System.... 16

a. Determination of rainfall collection efficiency of $42 \times 29 \times 25 \mathrm{~cm}$ and $11 \times 10 \times 4 \mathrm{~cm}$ plastic containers..................

b. Collection efficiency of various surfaces for dry fallout and total fallout samples

c. Dissolution of $\mathrm{Na}$ and $\mathrm{Mg}$ in the dry fallout samples from the bottom and sides of the plastic buckets............ 
d. Efficiency of the automatic rain dry

fallout collector for total deposition.... 24

B. Analytical Procedures................... 27

1. Extraction of $\mathrm{Na}$ and $\mathrm{Mg}$ from Whatman 41

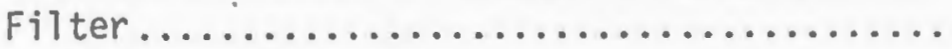

a. Extraction of known amounts of $\mathrm{Na}$ and

Mg from Whatman 41 filter...............

b. U1trasonic extraction versus high tem-

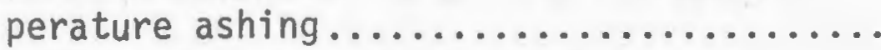

c. Extraction of particulate $\mathrm{Na}$ and $\mathrm{Mg}$

from Whatman 41 filter samples using

$0.1 \mathrm{~N} \mathrm{HNO}_{3}$ and distilled deionized water.,..

d. Efficiency of recovery of one extraction

for particulate $\mathrm{Na}$ and $\mathrm{Mg} . \ldots \ldots \ldots \ldots \ldots, 36$

2. Sample Analysis..................... 38

a. Atomic absorption................... 38

b. Sampling and analytical precision....... 41

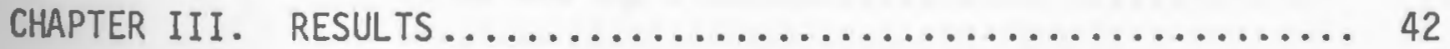

A. General Consideration ................... 42

B. Classification of Samples ................ 42

1. Atmospheric Concentrations and Dry Deposition.. 42

a. Coastal Rhode Island................ 42

i. "Marine", "mixed" and "1and"

samples..................... 42

ii. "Corrected-to-Marine" samples........ 47

b. Samples collected aboard RV/Trident...... 53 
c. Deposition velocity for particulate

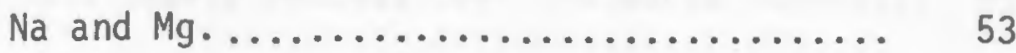

2. Rainfall Samples ....................... 60

CHAPTER IV. DISCUSSION .............................. 64

A. The Rate and Processes of Removal of Atmospheric

Sea Salt............................ 64

1. Dry Removal of Atmospheric Sea Salt......... 64

a. The rate of dry fallout and atmospheric concentrations of $\mathrm{Na}$ and $\mathrm{Mg}$ for samples collected in the "Marine", "mixed" and "land" subenvironments of R.I. environment

b. "Mixed" samples collected within the "010-090" wind sector ............... 73

c. Samples collected aboard RV/Trident...... 76

d. The $\mathrm{Mg} / \mathrm{Na}$ ratios .................... 76

e. Deposition velocities for particulate $\mathrm{Na}$ and $\mathrm{Mg}$.

2. Wet Removal of Atmospheric Sea Salt......... 78

a. Rainfall collected from different

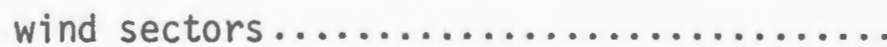

b. Selective removal of sea salt aerosol

by rainfall $\ldots \ldots \ldots \ldots \ldots \ldots \ldots \ldots \ldots$

B. Geochemistry of Atmospheric Sea Salt.......... 84

1. Significance of Wet Removal (rain) of sea salt Relative to Dry Deposition in the Coastal Environment of Rhode Is]and....... 
2. Sea Salt Yearly Removal Over the World Oceans... 84

3. Significance of Atmospheric Removal of Sea

Salt Over the Coast of Rhode Island.......... 85

4. Atmospheric Removal of $\mathrm{Na}$ and Mg Over Land..... 87

CHAPTER $v$. CONCLUSIONS $\ldots \ldots \ldots \ldots \ldots \ldots \ldots \ldots \ldots \ldots \ldots . \ldots . \ldots . \ldots . \ldots$

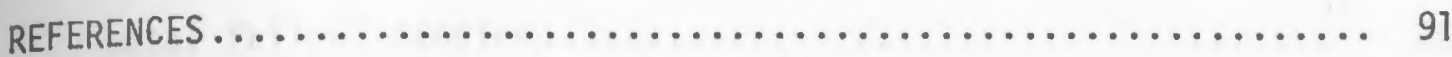




\section{LIST OF TABLES}

Table

1. Collection efficiency of rainfall by $42 \times 29 \times 25 \mathrm{~cm}$ and

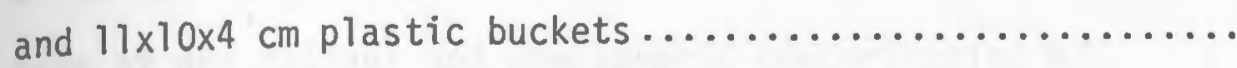

2. Surface collection efficiency for dry fallout and

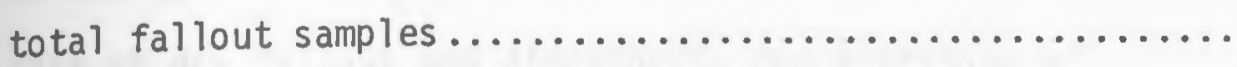

3a. Dissolution of $\mathrm{Na}$ and $\mathrm{Mg}$ in the dry fallout samples

from the bottom and sides of the plastic buckets.........

3b. Proportions of $\mathrm{Na}$ and $\mathrm{Mg}$ in the dry fallout collected on the bottom and sides of the plastic buckets...........

4. Efficiency of the automatic rain-dry fallout collector for total deposition $\ldots \ldots \ldots \ldots \ldots \ldots \ldots \ldots \ldots \ldots$

5. Extraction of known amounts of $\mathrm{Na}$ and $\mathrm{Mg}$ from a Whatman 41 filter using $0.1 \mathrm{~N} \mathrm{HNO}_{3}$ acid and an ultrasonic cleaner.

6. Extraction of $\mathrm{Na}$ and $\mathrm{Mg}$ from Whatman 41 filters using high temperature ashing and extraction with $0.1 \mathrm{~N}$ $\mathrm{HNO}_{3}$ in an ultrasonic bath 30

7. Extraction of particulate $\mathrm{Na}$ and $\mathrm{Mg}$ from a Whatman 41 filter blank using $0.1 \mathrm{~N} \mathrm{HNO}_{3}$ and D.D. $\mathrm{H}_{2} \mathrm{O}$ and an ultrasonic bath.

8. Extraction of particulate $\mathrm{Na}$ and $\mathrm{Mg}$ from atmospheric particulate sample No. 14

9. Extraction of particulate $\mathrm{Na}$ and $\mathrm{Mg}$ from atmospheric particulate sample No. 15.

10. Efficiency of extraction of atmospheric $\mathrm{Na}$ and $\mathrm{Mg}$ from Whatman 41 filter using ultrasonic cleaner and

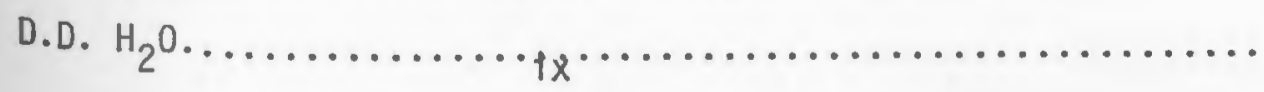


11. Sample collection information.................... 43

12. Rate of dry fallout and atmospheric concentration of $\mathrm{Na}$ and $\mathrm{Mg}$ for "marine" samples.................. 48

13. Rate of dry fallout and atmospheric concentration of $\mathrm{Na}$ and $\mathrm{Mg}$ for "land" samples..................... 49

14. Rate of dry fallout and atmospheric concentration of

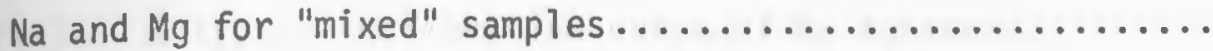

15. "Corrected-to-marine" rate of dry fallout and atmospheric concentrations of $\mathrm{Na}$ and $\mathrm{Mg}$ for "mixed" samples....

16. "Marine" samples and "Corrected-to-marine" samples correlation with wind speed $\ldots \ldots \ldots \ldots \ldots \ldots \ldots \ldots$

17. Rate of dry fallout and atmospheric concentrations of $\mathrm{Na}$ and $\mathrm{Mg}$. Wind direction $010-090^{\circ} \ldots \ldots \ldots \ldots \ldots \ldots$

18. Atmospheric flux of $\mathrm{Na}$ and $\mathrm{Mg}$ to the North Atlantic Ocean (R/V Trident samples) $\ldots \ldots \ldots \ldots \ldots \ldots \ldots \ldots \ldots \ldots$

19. Deposition velocities for atmospheric $\mathrm{Na}$ and $\mathrm{Mg} . . . . . . .58$

20. $\mathrm{Na}$ and $\mathrm{Mg}$ in "marine" rain samples................... 67

21. $\mathrm{Na}$ and $\mathrm{Mg}$ in "mixed" rain sampies................... 62

22. $\mathrm{Na}$ and $\mathrm{Mg}$ in "land" rain samples................... 63

23. Summary table for rain and dry fallout samples

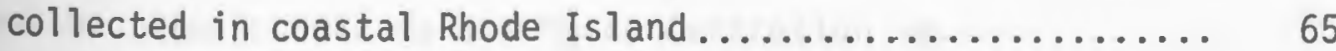

24. Geochemistry of cyclic sea salt.................. 86 
Figure 1. Effects of varying wind force upon number and weight of large sea-salt particles near cloud

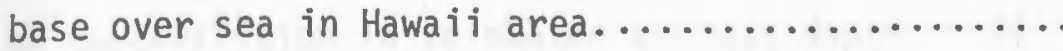

Figure 2. The automatic rain-dry fallout collector.

Only the dry fallout half is shown (The rain half is identical)

Figure 3. A typical calibration curve of $\mathrm{Na}$ concentration versus absorbance, with burner head rotated at $90^{\circ} \ldots \ldots \ldots \ldots \ldots \ldots \ldots \ldots \ldots \ldots \ldots \ldots \ldots \ldots \ldots$

Figure 4. A typical calibration curve of Mg concentration versus absorbance, with burner head

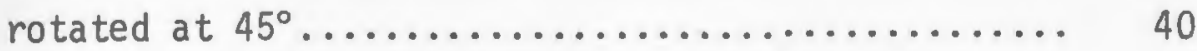

Figure 5. Coastal Rhode Island sampling site............. 46

Figure 6. R/V Trident cruise \#169, sampling stations....... 59

Figure 7. Atmospheric $\mathrm{Na}$ and $\mathrm{Mg}$ concentration vs.

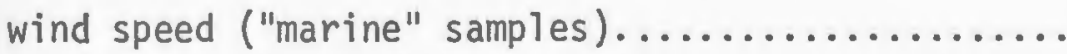

Figure $8 . \quad \mathrm{Na}$ and $\mathrm{Mg}$ rate of dry fallout vs. wind speed ("marine" samples)

Figure 9. $\mathrm{Na}$ and $\mathrm{Mg}$ rate of dry fallout vs. wind speed ("land" samples)

Figure 10. Atmospheric $\mathrm{Na}$ and $\mathrm{Mg}$ concentration vs. wind speed ("marine" and "corrected-tomarine" samples).

Figure 11. Na and Mg rate of dry fallout vs. wind speed

("marine", "corrected-to-marine" and

Trident samples). 
Figure 12. $\mathrm{Na}$ and $\mathrm{Mg}$ concentration in rain water vs. wind speed ("marine" rain)............. 80

Figure 13. Na concentration in rainwater vs rain depth. 81 Figure 14. Mg concentration in rainwater vs. rain depth............................ 82 


\section{INTRODUCTION}

It appears that a Hungarian geologist named Posephny was the first person to visualize the geochemical implication of sea salt transport between the ocean, the atmosphere, and land in 1877 (Eriksson 1959). Posephny used geological evidence to conclude that chloride in river water and saline deposits must have originated in the sea and been carried inland by the atmosphere. Posephny's observation went largely without notice until 1959 when Erik Eriksson, in Sweden, made the first quantitative estimations for the removal of atmospheric sea salt by rainfall and dry deposition over the ocean and land. This will be discussed in full detail later.

A. Removal Mechanisms of Atmospheric Sea Salt

Junge (1963) classified the removal mechanisms for atmospheric aerosols as wet removal by precipitation, dry removal by sedimentation, and dry removal by impaction on obstacles on the earth surface. The third mechanism can be important in land covered with forests (Junge 1963; Madgwick and Ovington, 1959; Georgi i 1962).

Wet removal comprises two distinct processes 1) rainout, which is the removal due to processes within the clouds, and 2) washout, which is the process of removal by rainfall below the clouds. During the journey of the raindrops from the cloud base downwards, in addition to the washout processes, evaporation of the raindrops also occurs. The net effect of these three processes, namely rainout, washout and evaporation, determine the concentration of any substance in rain water.

During the rainout process, atmospheric aerosols enter the cloud droplets in the following ways: 
1) Consumption of condensation nuclei,

2) The attachment of aerosol particles to the cloud elements by Brownian motion,

3) The attachment of aerosol particles by the water vapour gradient (Facy-effect). For atmospheric sea salt and other aerosol particles of radi $i>0.1$ um, the consumption of condensation nuclei is considered the primary mechanism of rainout. The other two mechanisms, 2 and 3 are important for Aitken particles (radi i < 0.1 um), (Junge 1963).

Martens, et al. (1973), observed a chemical change during the transformation of aerosols to cloud droplets on the eastern end of the island of Puerto Rico. Comparison of elemental ratios in particles and rain and of the elemental particle size distribution in and out of the clouds showed an apparent efficiency of $700 \%$ for the marine particles ( $\mathrm{Na}, \mathrm{I}, \mathrm{Br}, \mathrm{Cl}^{-}$) compared to less than $25 \%$ scavenging efficiency for the terrestrial fraction of the aerosol ( $A l, M n, V)$.

When the rain drops leave the cloud base, they scavenge aerosol particles as they fall and they begin to evaporate. Both these processes lead to an increase in the rain water concentration of dissolved substances. Washout and evaporation are both inversely proportional to the radius of the rain drop (Junge, 1963).

$$
k \propto \frac{1}{r_{c}}
$$

where $K$ is the concentration of any dissolved substance in rain water due to washout and evaporation and $r_{c}$ is the rain drop radius. Although the mass of sea salt collected by a rain drop falling through air containing sea salt depends upon the volume of air swept out by 
the falling drop, i.e., proportional to the cross-sectional area of the falling drop or $r_{c}^{2}$, the concentration of salt in the rain drop is inversely proportional to the volume of the rain drop or $1 / r_{c}{ }^{3}$. The net salinity change would be proportional to $1 / r_{c}$. In addition small rain drops become more saline than larger ones due to evaporation. Again, although evaporation is proportional to the surface area of the drop or $r_{c}{ }^{2}$, the salinity is proportional to $1 / r_{c}{ }^{3}$ (Turner 1955 ; Duce, et al., 1969). Duce et al., 1969 measured the $\mathrm{Na}^{+}$and $\mathrm{Cl}^{-}$content of rain as a function of rain intensity. Large raindrops were associated with higher rainfall intensity. They found that high intensity rains were associated with low concentrations of $\mathrm{Na}^{+}$and $\mathrm{Cl}^{-}$while low intensity rain showers results in rains with higher amounts of $\mathrm{Na}^{+}$and $\mathrm{Cl}^{-}$. The $\mathrm{Na}^{+} / \mathrm{Cl}^{-}$ratio, however, was found to be constant, independent of evaporation, washout or the intensity of rain.

\section{B. Review of the History of Sea Salt in Rain Water}

Although the history of research on chemical compounds in rain and snow date back to 1750 (Eriksson, 1959), for a long time ammonia and nitrate nitrogen were the only compounds of interest. The first determination of sea salt in rain water was made at the beginning of the nineteenth century, when several investigators around the world measured $\mathrm{Cl}^{-}$in rain water collected at coastal and inland locations, (Eriksson, 1952). Although the geochemical significance of atmospheric transport of sea salt between the ocean and land was suggested by Posephny as early as 1877, 1ittle was done to evaluate the processes of production and removal of atmospheric sea salt until the middle of the 20th century. During this early period in the history of atmospheric sea salt chemistry, the majority of the studies done were concerned 
with measuring chloride and/or other sea salt components in rainwater collected over specified periods of time. This was undertaken in several localities around the world, including inland and marine areas. Eriksson (1952) extensively reviewed the various studies during this period. Some of this pioneer work, as quoted from Eriksson's review (1952), merits mentioning. Two points, however, should be made before proceeding further. Firstly all these reported values of sea salt in rain and in snow include dry deposition as well, because it appears that the total deposition was measured, not rainfall alone. secondly, most of these investigations were not done under meteorologically controlled or monitored conditions, and hence the results cannot be taken as strictly representative of marine or continental environments.

Although the first determination of chloride in rain water was made at the beginning of the nineteenth century, systematic work was not published until 1851 when Arago in Paris reported monthly amounts of $\mathrm{Cl}^{-}$in rain water for a half year period. Another systematic investigation was carried out by Smith in 1872, He analysed rain water collected at different places in the British Isles. His reported values for the chloride content of rain water showed a considerable variation with a maximum of $54.6 \mathrm{mg} / \mathrm{l}$ on the west coast of England and a minimum of $1.20 \mathrm{mg} / 1$ in London. Smith, however, could not determine the cause of this considerable variation (Eriksson, 1952).

In Eriksson's review tables of the $\mathrm{Cl}^{-}$content in $\mathrm{mg} / \mathrm{l}$ of rain $\mathrm{fall}$ collected in Europe, America, Asia, Africa, New Zealand and Australia were presented. From these data, Eriksson found that the $\mathrm{Cl}^{-}$content 
of rain water is always higher in coastal areas compared to inland places. He also noticed that the concentrations of $\mathrm{Cl}^{-}$in rain water do not vary much in inland places whereas coastal locations show a great variation. Remarkably, high concentrations have been observed at Mt. Vernon, Iowa in the Unițed States, although it is located inland far from both the Atlantic and Pacific oceans, (Trieschmann, 1919; Knight, 1920; Shaffer, 1921; Fries, 1923; Woehlk, 1923; Knight, 1924; Kynett, 1929; Krehl et. a1., 1935). At this location one of the longest series of analyses of $\mathrm{Cl}^{-}$in rain was carried out, covering the period 1919-1935. As there is no other likely souce for the $\mathrm{Cl}^{-}$ in the rain, it must be assumed that most of it originated from the ocean and was transported inland.

Extremely high amounts of salt falling with rain and snow were also reported in central Russia (see for example Krivopalova, 1971 ;Yushkevich, 1971; Kashtanov, 1968). They measured $\mathrm{Na}^{+}, \mathrm{Mg}^{++}, \mathrm{K}^{+}, \mathrm{Ca}^{++}, \mathrm{Cl}^{-}, \mathrm{SO}_{4}^{--}$, $\mathrm{CO}_{3}$. Although it is possible that a fraction of these ions in the rain and snow originated in the sea and was carried inland by the atmosphere, it appears that most of them were crustal since the ionic ratios in these samples approached the crustal values. Zverev, et. al., (1973) determined the average chemical composition of atmospheric precipitation for $10 \mathrm{climatic}$ zones of the USSR. He found that the mean cancentrations for the USSR were:

$$
\begin{aligned}
& \mathrm{Na}=3.14 \quad \mathrm{mg} / 1 \\
& \mathrm{Mg}=0.70 \quad " \\
& \mathrm{Ca}=3.37 \quad " \\
& \mathrm{~K}=0.645 \quad " \\
& \mathrm{Cl}^{-}=3.89 \quad
\end{aligned}
$$


Contrary to the previous Russian data, these values suggest that much of the $\mathrm{Na}^{+}$and $\mathrm{Cl}^{-}$in rainfall in USSR may be of oceanic origin, as the $\mathrm{Na} / \mathrm{Cl}$ ratio of 0.81 approaches that of sea water, 0.55 . This data, however does not give typical sea salt ratios for cations. It is likely that the deviations are.due to the inclusion of crustal material containing these metals.

Francesco Palmieri (1966) studied the salt content of rainfall in Caserta, on the southern coast of Italy. He determined a total depth of rainfall of $63 \mathrm{~cm} /$ year. He calculated a yearly total deposition for $\mathrm{Na}$ of $347 \mu \mathrm{g} / \mathrm{cm}^{2} ; \mathrm{Mg}, 61.9 \mu \mathrm{g} / \mathrm{cm}^{2} ; \mathrm{K}, 121 \mu \mathrm{g} / \mathrm{cm}^{2}$, and $\mathrm{Ca}, 33.8 \mu \mathrm{g} / \mathrm{cm}^{2}$. A7though his data gives a $\mathrm{Mg} / \mathrm{Na}$ ratio of 0.18 compared with a sea salt ratio of 0.12 , the $\mathrm{K} / \mathrm{Na}$ and $\mathrm{Ca} / \mathrm{Na}$ ratios are very high compared to their sea water ratios, which are: $\mathrm{K} / \mathrm{Na}-0.038, \mathrm{Ca} / \mathrm{Na}=0.038$ (Riley and Chester, 1971). Since Caserta is on the coast it seems that the deviations in the $\mathrm{K} / \mathrm{Na}$ and $\mathrm{Ca} / \mathrm{Na}$ ratios (as well as the $\mathrm{Mg} / \mathrm{Na}$ ratio) are due to the addition of crustal $\mathrm{K}$ and $\mathrm{Ca}$ to the samples.

Zhavoronkina, (1958) in Russia observed that the salt content of rain iacreased in winter and decreased in summer in coastal areas. He explained the salt increase in winter as being due to winter storms over the ocean. Girenko, (1959) made a more detailed investigation of the effect of weather on the total mineral content of rain and snow. He concluded from his study of an annual cycle that the maximum mineral content in rain corresponds to the lowest amounts. of precipitation, the largest period of drought between rainfall, and the most frequent strong winds during the corresponding month.

Mather (1960) reviewed and summarized results of chloride analyses in rain water from different $\mathrm{places}$ around the world. Based on Mather's 
and Eriksson's reviews (1952) the following can be deduced.

1. The ocean is the major souce of airborne salt. This is clearly shown by the higher salt content of rain in coastal areas compared to inland zones.

2. The concentration of sea salt in precipitation shows an annual and geographic variation.

3. The composition of salt in precipitation deviates from the characteristic sea water ratios as one goes inland.

C. Mechanisms of Production of Atmospheric Sea salt Particles:

It is generally believed that sea salt particle with atmospheric residence time longer than a few minutes are produced by bubbles bursting at the sea surface. Blanchard and Woodcock (1957) investigated the various processes for bubble production at the sea surface. They found that breaking waves, or white caps are the most important mechanism for bubble formation. Sea salt particles are produced and injected in the atmosphere when these bubbles burst. (Boyce, 1951). Kientzler et al. (1954) showed that immediately after a bubble bursts on the ocean surface, it forms a bubble jet which ejects 2 to 5 droplets into the air. The diameter of the jet droplet is usually $210 \%$ of the bubble diameter from which they form (Blanchard, 1963). Mason (1957) and Blanchard (1963) found that when the bubbles burst, other droplets were also formed due to the shattering of the bubble film cap. Little is known about the size and number distribution of these film drops. In addition little is known about the size and number of bubbles in the open ocean under various wind speed conditions. Blanchard and Hoodcock (1957) studied the distribution of bubbles between $75 \mu \mathrm{m}$ and $750 \mu \mathrm{m}$ diameter in waves breaking on a beach. Their experimental set up did not allow them to measure larger size bubbles. 
Medwin $(1970,1977)$ used acoustic attenuation measurements to study bubbles size distribution and densities in coastal waters. He investigated bubbles of radius of 15-300 um at depth of 3-36 meters. He found relationships between the bubble size or densities and the season, time of day, wind speed and presence or absence of sea slicks. He postulated that micro bubbles are entrained by aerosols as they fall into the ocean as well as produced by biological activity. Blanchard (1963) estimated that at any moment $\sim 3 \%$ of the ocean surface is covered by white caps.

D. Seochemical cycle of Atmospheric Sea Salt

The size distribution of sea salt particles in the marine atmosphere was investigated by Woodcock and coworkers. Woodcock (1953) determined the size distribution of sea salt below the cloud base $(500 \mathrm{~m})$ over Hawai and other marine and continental areas. He did this for several wind forces (Fig. 1). He found that the number and size of particles or airborne sea salt increase with increasing wind force and with decreasing altitude above the sea.

Using the size distribution of Woodcock (1953, Fig. 1), and assuming a mean wind speed of 12 knots, Eriksson (1959), utilized Stokes Law to calculate the flux of sea salt particles that would be expected to fall through the surface laminar boundary layer into the sea. In the steady state this output should be equal to the total rate of production of sea salt particles in the area of the whitecap, from the ocean surface. Eriksson calculated the rate of dry fallout over Hawai Florida. He deduced an average dry deposition rate of $5.5 \times 10^{-12} \mathrm{gm}$ $\mathrm{cm}^{-2} \mathrm{sec}^{-1}$ of sea salt. The rate of removal over the entire ocean surface is then $5.4 \times 10^{14} \mathrm{~g}$ per year. He used rain and river runoff $\mathrm{Cl}^{-}$data 
Figure 1. Effects of varying Beaufort wind force upon number and weight of large sea/salt particles near cloud base over sea in Hawai i area. After Woodcock (1953). 


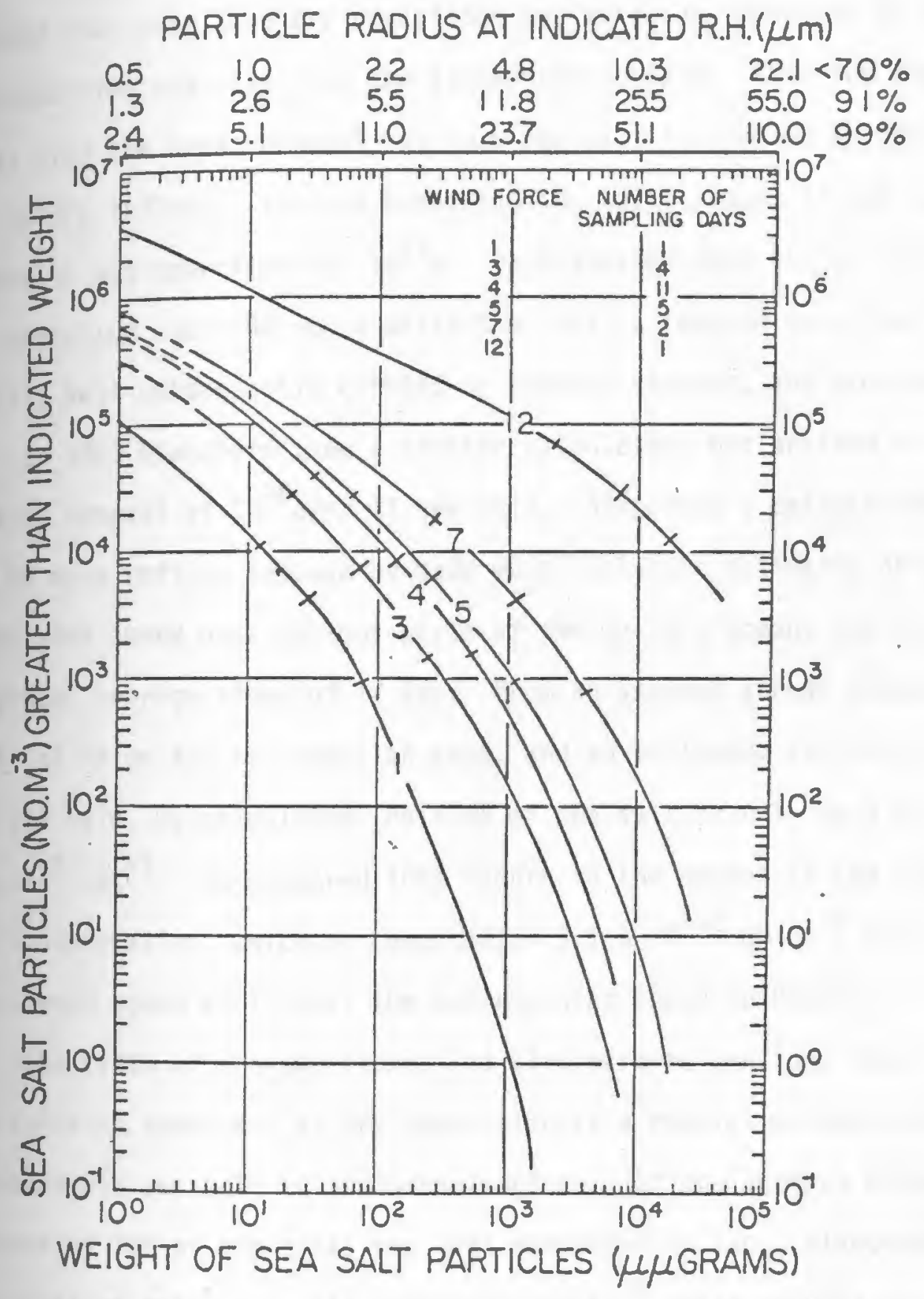


from Scandinavia. He found that the ratio of $\mathrm{Cl}^{-}$concentration in rain water relative to $\mathrm{Cl}^{-}$concentration in river runoff was 0.3 . He concluded that over land dry deposition was twice as important as rain in transporting sea salt from the atmosphere to land. This led him to believe that over the ocean probably as much sea salt is removed by precipitation as by dry fallout. Thus he suggested the total amount of sea salt removed annually was approximately $10^{15} \mathrm{~g}$. He estimated that $90 \%$ of this amount is deposited over the ocean while the rest is removed over land as the cyclic salt subsequently carried by rivers, streams, and groundwater.

In 1963 Blanchard made a similar calculation but arrived at a yearly removal of $10^{16} \mathrm{~g} / \mathrm{yr}$ of sea salt. Blanchard's calculation seems to be more refined because he made more realistic estimates of the mean wind speed over various parts of the world's ocean, not relying on a global average speed of $12 \mathrm{kts}$. From an assumed annual oceanic rainfall of $89 \mathrm{~cm}$ for the Hawaian area, and an estimated salinity of $3.4 \mathrm{mg} / \mathrm{l}$ in the rain, he calculated the flux of sea salt by rain as $9.60 \times 10^{-12}$ $\mathrm{gm} \mathrm{cm}^{-2} \mathrm{sec}^{-1}$. He compared this figure to the amount of sea salt fallout by sedimentation, which he computed as $5.1 \times 10^{-12} \mathrm{gm} \mathrm{cm}^{-2} \mathrm{sec}^{-1}$ at a wind speed of $12 \mathrm{kts}$, the average wind speed in Hawaii.

The ratio of the two fluxes led $B l$ anchard to conclude that rainfall is twice as important as dry deposition as a removal mechanism of atmospheric sea salt to the ocean surface. If one accepts Eriksson's figure of $10 \%$ of the total sea salt deposited on land, Blanchard's estimate of total sea salt production of $10^{16} \mathrm{gm} / \mathrm{yr}$ results in an estimated amount of cyclic sea salt deposited over land of $210^{15} \mathrm{~g} / \mathrm{yr}$. Livingstone (1963) calculated that the annual global input of cyclic sea salt from river runoff into the ocean is approximately $3 \times 10^{14} \mathrm{~g} / \mathrm{yr}$, in between the estimates of Blanchard and Eriksson. 
Cawse et. a1. (1972, 1974) made a two year analytical study of trace elements in the atmospheric environment in the United Kingdom. They measured the concentration of 30 trace elements in airborne dust, rain water, and dry deposition at several localities. From these measurements they calculated a.dry deposition velocity for each element. The deposition velocity, in $\mathrm{cm} / \mathrm{sec}$, was defined as the rate of dry deposition in ug $\mathrm{cm}^{-2} \mathrm{sec}^{-1}$ divided by the concentration in air in $\mu \mathrm{g} / \mathrm{cm}^{3}$. They calculated the ratio of dry deposition to total deposition for $\mathrm{Na}^{+}$and for $\mathrm{Cl}^{-}$as $5 \%$, i.e. rainfall was by far the major removal pathway.

Tsunogai (1975) investigated sea salt transport to land in Japan. He found that the share of dry sedimentation was only $20 \%$ of the total removal over the various parts of Japan. Most of this $20 \%$ was transported during discrete events such as Summer typhoons.

\section{E. Search Objectives}

It can be seen that rainfall and dry fallout are the two main routes by which atmospheric sea salt is transported back to the ocean and to the 7and. As mentioned earlier, the total amount of atmospheric sea salt particles produced by the ocean is apparently in the range of $10^{15} \mathrm{~g} / \mathrm{yr}-10^{16} \mathrm{~g} / \mathrm{yr}$. The primary objectives of this present investigation are to:

1. Test the validity of the two estimates of annual production of atmospheric sea salt particle.

2. Investigate and determine by chemical analyses the rate of dry and wet removal (rain) of atmospheric sea salt ( $\mathrm{Na}$ and $\mathrm{Mg}$ ) from the marine and near shore Rhode Island atmosphere to the earth surface, and to establish empirically the relationship between the rate of dry 
and wet removal (rain) and wind speed and direction on the Rhode Island coast.

3. Assess the role of dry fallout in comparison to wet removal (rain) of sea salt from the marine and coastal Rhode Island atmosphere.

4. Calculate atmospheric deposition velocities to the earth surface in the coastal Rhode Island environment for particulate $\mathrm{Na}$ and $\mathrm{Mg}$. Dry deposition velocity $V_{g}$ has been defined (Chamberlain, 1960) as:

$$
V_{g}\left(\mathrm{~cm} \mathrm{sec}^{-1}\right)=\frac{\text { rate of dry deposition }\left(\mu \mathrm{g} \mathrm{cm}^{-2} \mathrm{sec}^{-1}\right)}{\text { concentration in air }\left(\mu \mathrm{g} \mathrm{cm} \mathrm{cm}^{-3}\right)}
$$




\section{EXPERIMENTAL METHODS}

A. Sampling Procedures:

1. General Considerations:

Rainfall, dry fallout, total deposition and atmospheric particulate samples were collected at the Narragansett Bay campus of the University of Rhode Island in southern R.I. The roof of a mobile trailer, which was approximately 2.5 meters above the ground, was used as an atmospheric sampling station. The station is approximately 150 meters west of the west coast of Narragansett Bay and 15 meters above sea level. A field recording wind system (model R.M. Young, 1973), was installed on the sampling station to provide a continuous record of wind speed and direction. Also a standard plastic rain gauge was used to record the amounts of rainfall.

Seventeen rainfall samples, 55 dry fallout samples and 28 atmospheric particulate samples were collected. The majority of these samples were collected during 24 hour periods continually from April 15 to June 28, 1976. A few rainfall and dry fallout samples were collected during December 1975. Duplicates of seven dry fallout samples were collected aboard RV/Trident, Cruise \#169, Narragansett to Bermuda to Narragansett during July, 1975. These samples were collected manually on top of the wet laboratory.

The majority of the rainfall and dry fallout samples were collected in duplicate and a few in triplicate. Acid cleaned $11 \times 10 \times 4 \mathrm{~cm}$ and/or $42 \times 29 \times 25 \mathrm{~cm}$ plastic containers were used for this purpose. The atmospheric samples were collected on double Whatman 41 filters using a high volume pump. These filters are reported to be $90 \%$ efficient for removing particles $\geq 0.26$ um in diameter for air (Stafford and Ettinger, 1972). Also the blank content of $\mathrm{Na}$ and $\mathrm{Mg}$ in these filters is low (Cawse et al., 1972; Dams et al., 1972). 
Out of the total number of dry fallout and rainfall samples, 34 dry fallout and 7 rain samples were collected using the automatic rain-dry fallout sampler (Fig. 2), while the rest were collected manually. Manual rain samples were obtained by sampling the rain shower beainning immediately after the start of the shower and ending as soon as the rain stopped. Dry fallout samples were collected during dry periods. Whenever rainfall was collected with dry fallout samples, as was the case sometimes at inconvenient hours, the collected samples were considered as total fallout samples.

2. The Automatic Rain-Dry Fallout Collector (AEC)

This automatic collector is a modification of a device designed and built by Dr. Herbert Volchok of the Health and Safety Laboratory, ERDA, N.Y., N.Y. The system as shown (Fig. 2) consists of a two polyethylene bucket collector controlled by a printed circuit board rain sensor. Each collector was desinged to house precisely a polyethylene bucket of a size $42 \times 29 \times 25 \mathrm{~cm}$. This way only single samples could be collected by the collector. In order to collect dry fallout replicate samples using the automatic collector, the system was modified as follows: a wooden platform wrapped with polyethylene sheets and having the same size as the plastic buckets was placed in the collector instead of the dry fallout bucket. This platform was designed to house as many as 4 polyethylene buckets of a size $11 \times 10 \times 4 \mathrm{~cm}$. During rainfall one vessel is exposed and collects rain while the dry fallout vessel (or vessels) is covered. When it is not raining the dry fallout collector(s) is exposed and the rain collector is covered. A heater is attached to the sensor to assure activation during cold periods and to dry the sensor so that a quick shut-off will occur at the end of precipitation. 

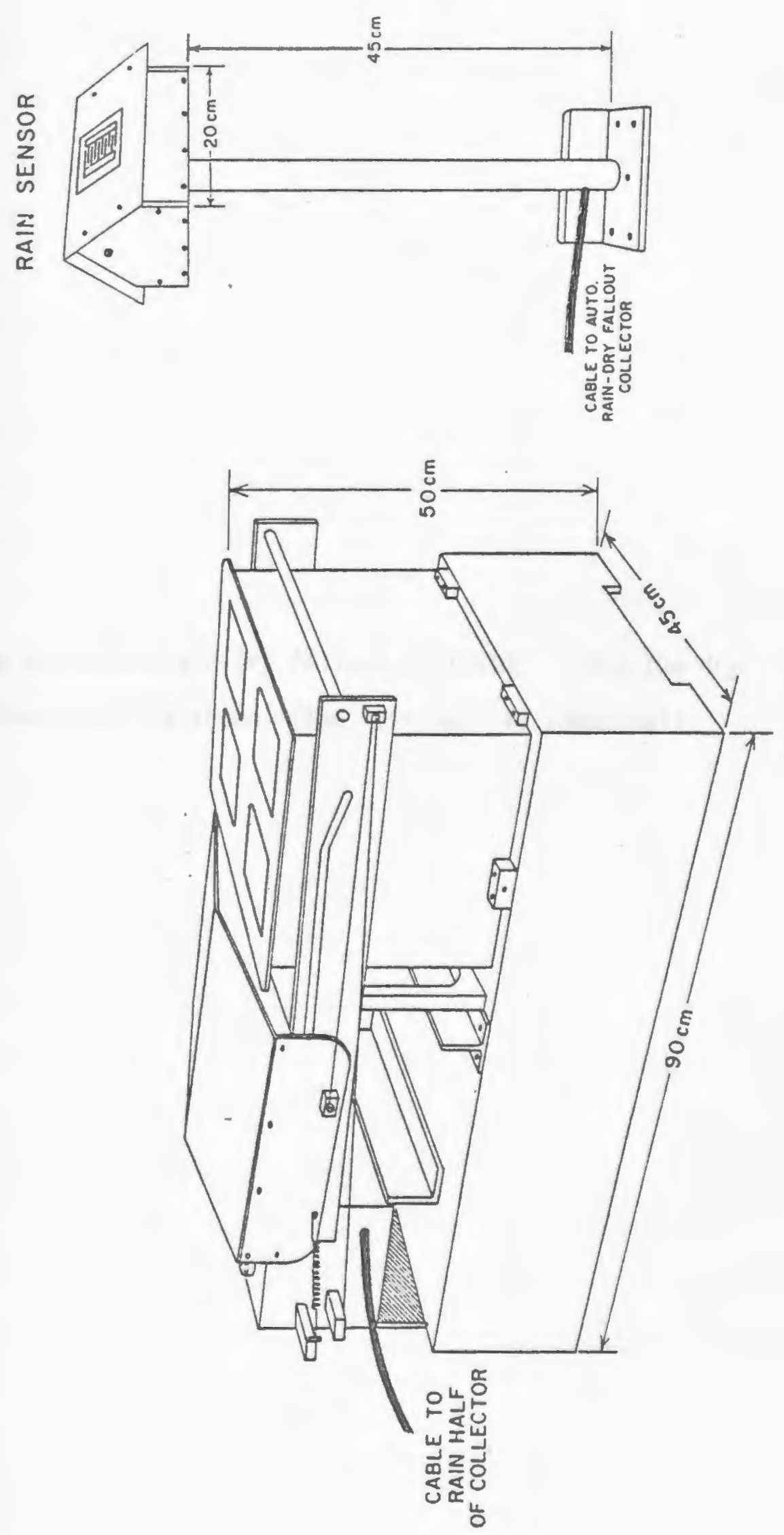
Figure 2. The automatic rain-dry fallout collector. Only the dry fallout half is shown. (The rain half is identical). 


\section{Sample Handling}

Dry fallout samples were obtained by washing the bottom and sides of the plastic buckets with distilled deionized water after sampling. Samples were stored in acid cleaned polyethylene bottles and kept in a freezer. Blanks were obtained twice for every sample. The first blanks were taken from the clean plastic collection container before sampling using distilled deionized water. The second blanks were taken from the distilled deionized water used to wash out the dry fallout samples.

Total fallout and rainfall samples were also stored in acid cleaned polyethylene bottles, kept in a freezer. For those samples of large volumes only aliquots were retained and the rest of the sample was disposed of after determining the total volume.

Whatman 41 filter blanks were obtained periodically for the atmospheric particulate samples by treating filter blanks exactly as sample filters, except no air was drawn through them. Sample filters and blanks were sealed in polyethylene bags and stored in a freezer prior to analys is.

4. Testing Programs for the Sampling Systems

To determine the optimum conditions for sample collection, several tests were conducted prior to the start of the sampling program for this project. These tests, discussed in full below, included the following: determination of the collection efficiency of two types of plastic buckets for rainfall and dry fallout, collected manually and automatically; investigation of the collection efficiency of 3 type of surfaces for dry fallout collection; and determination of the collection reliability of the automatic rain-dry fallout sampler. 
a. Determination of rainfall collection efficiency of $42 \times 29 \times 24 \mathrm{~cm}$
and $11 \times 10 \times 4 \mathrm{~cm}$ plastic containers.

The total volume of 13 rain showers collected in $42 \times 29 \times 25 \mathrm{~cm}\left(1233 \mathrm{~cm}^{2}\right.$ bottom area) and $11 \times 10 \times 4 \mathrm{~cm}\left(110 \mathrm{~cm}^{2}\right.$ bottom area) plastic buckets was measured. Seven of these rain shower samples were collected manually and 6 of them were collected using the automatic rain dry fallout sampler. Manual samples were collected in duplicate and triplicate. During rain shower number 5 , two sets of samples, 5I and 5II were collected.

The collection efficiency of the two types of plastic containers and collection methods were calculated relative to the total rainfall masurements obtained from the standard plastic rain gauge. The results, shown in Table (1) indicate that the two types of collectors and collection efficiency for each of the two sized of plastic containers was $98 \%$. The mean collection efficiency for the automatic collector which used the larger bucket, was also $98 \%$, with sample number 12 not included. The overall efficiency for all collectors was also $98 \%$.

b. Collection efficiency of various surfaces for dry fallout and total fallout samples.

Seven experiments were conducted to determine what type of collection surface should be utilized to collect dry fallout samples. Three types of surfaces were investigated.

1. A dry plastic bucket surface

2. A water surface,

where distilled deionized water was added to the bucket to make a thin film of water at the bottom of the bucket.

3. A Whatman 41 filter surface. 
Table 1. Collection efficiency of rainfall by $42 \times 29 \times 25 \mathrm{~cm}$ and $11 \times 10 \times 4 \mathrm{~cm}$ plastic buckets

\begin{tabular}{|c|c|c|c|c|c|c|c|}
\hline $\begin{array}{c}\text { Rain } \\
\text { Sample }\end{array}$ & Date & $\begin{array}{l}\text { Bucket Boţtom } \\
\text { Area }\left(\mathrm{cm}^{2}\right)\end{array}$ & $\begin{array}{l}\text { Total } \\
\text { Volume }\end{array}$ & $\begin{array}{l}\text { Ra in } \\
\left\langle\mathrm{cm}^{3}\right\rangle\end{array}$ & $\begin{array}{l}\text { Calculated } \\
\text { Rain Depth } \\
(\mathrm{cm})\end{array}$ & $\begin{array}{l}\text { Ra in Gauge } \\
\text { Depth } \\
\text { (cm) }\end{array}$ & $\begin{array}{c}\text { Efficiency } \\
(\dot{x})\end{array}$ \\
\hline \multirow[t]{4}{*}{1} & $12 / 30 / 75$ & 110 & 182 & & 1.65 & 1.50 & 110 \\
\hline & & $\begin{array}{l}110 \\
110\end{array}$ & $\begin{array}{l}190 \\
189\end{array}$ & & $\begin{array}{l}1.70 \\
1.70\end{array}$ & $\begin{array}{l}1.50 \\
1.50\end{array}$ & $\begin{array}{l}113 \\
113\end{array}$ \\
\hline & & 1233 & 1810 & & 1.50 & 1.50 & 100 \\
\hline & & 1233 & 1880 & & 1.50 & 1.50 & 100 \\
\hline \multirow{6}{*}{2.} & $12 / 31 / 75$ & 110 & 89 & & 0.51 & 0.83 & 98 \\
\hline & & 110 & 93 & & 0.85 & 0.83 & 102 \\
\hline & & 110 & 91 & & 0.83 & 0.83 & 100 \\
\hline & 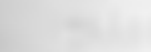 & 110 & 92 & & 0.84 & 0.83 & 107 \\
\hline & & $\begin{array}{r}110 \\
1233\end{array}$ & $\begin{array}{r}92 \\
1000\end{array}$ & & 0.84 & $\begin{array}{l}0.83 \\
0.83\end{array}$ & $\begin{array}{r}101 \\
08\end{array}$ \\
\hline & & 1233 & 1010 & & $\begin{array}{l}0.81 \\
0.82\end{array}$ & $\begin{array}{l}0.83 \\
0.83\end{array}$ & $\begin{array}{l}98 \\
99\end{array}$ \\
\hline \multirow[t]{3}{*}{3.} & $1 / 6 / 76$ & 110 & 422 & & 3.80 & 3.80 & 100 \\
\hline & & & $\begin{array}{l}418 \\
425\end{array}$ & & $\begin{array}{l}3.80 \\
3.90\end{array}$ & 3.80 & 100 \\
\hline & & 110 & 422 & & $\begin{array}{l}3.90 \\
3.80\end{array}$ & $\begin{array}{l}3.80 \\
3.80\end{array}$ & $\begin{array}{l}103 \\
100\end{array}$ \\
\hline 4. & $4 / 24 / 76$ & 110 & 115 & & 1.05 & 1.00 & 105 \\
\hline \multirow[t]{3}{*}{$5 I$} & $5 / 1 / 76$ & 110 & $\begin{array}{l}108 \\
255\end{array}$ & & 0.98 & 1.00 & 98 \\
\hline & & 110 & $\begin{array}{l}255 \\
265\end{array}$ & & $\begin{array}{l}2.30 \\
2.40\end{array}$ & $\begin{array}{l}2.60 \\
2.60\end{array}$ & 88 \\
\hline & & 110 & 260 & & 2.40 & 2.60 & $\begin{array}{l}92 \\
92\end{array}$ \\
\hline \multirow[t]{3}{*}{$5 I I$} & $5 / 1 / 76$ & 110 & 235 & & 2.14 & 2.50 & 86 \\
\hline & & 110 & 240 & & 2.20 & 2.50 & 88 \\
\hline & & 110 & 245 & & 2.20 & 2.50 & 88 \\
\hline \multirow[t]{2}{*}{6.} & $5 / 11 / 76$ & 110 & 96 & & 0.87 & 0.90 & 97 \\
\hline & & 110 & 97 & & 0.88 & 0.90 & 98 \\
\hline \multirow{4}{*}{7.} & $5 / 16 / 76$ & 110 & 181 & & 1.65 & 1.75 & 94 \\
\hline & & 110 & 189 & & 1.70 & 1.75 & 97 \\
\hline & & 110 & 213 & & 1.90 & 1.75 & 109 \\
\hline & & $\begin{array}{r}110 \\
1233\end{array}$ & 170 & & 1.60 & 1.75 & 97 \\
\hline \multirow[t]{2}{*}{8.} & $5 / 18 / 76$ & $\begin{array}{r}1233 \\
110\end{array}$ & $\begin{array}{r}2160 \\
35\end{array}$ & & $\begin{array}{l}1.75 \\
0.32\end{array}$ & 1.75 & 100 \\
\hline & & 110 & $\begin{array}{l}35 \\
36\end{array}$ & & $\begin{array}{l}0.32 \\
0.33\end{array}$ & $\begin{array}{l}0.35 \\
0.35\end{array}$ & 97 \\
\hline * & & 1233 & 405 & & $\begin{array}{l}0.33 \\
0.33\end{array}$ & $\begin{array}{l}0.35 \\
0.35\end{array}$ & $\begin{array}{l}94 \\
94\end{array}$ \\
\hline 9.* & $5 / 21 / 76$ & 1233 & 690 & & $\begin{array}{l}0.33 \\
0.56\end{array}$ & $\begin{array}{l}0.35 \\
0.53\end{array}$ & $\begin{array}{r}94 \\
105\end{array}$ \\
\hline $10 . *$ & $5 / 27 / 76$ & 1233 & 52 & & 0.04 & 0.04 & 100 \\
\hline $11 .:$ & $6 / 1 / 76$ & 1233 & 1650 & & 1.34 & 1.45 & 92 \\
\hline 12.* & $6 / 19 / 76$ & 1233 & 400 & & 0.32 & 0.40 & 80 \\
\hline \multicolumn{2}{|c|}{$\begin{array}{l}\text { Wean of } \\
\text { the samples }\end{array}$} & - & - & & & 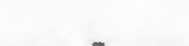 & \\
\hline & - & & - & & - & - & $98+7$ \\
\hline
\end{tabular}

* Samples collected using the automatic rain-dry fallout sampler. The rest of the samples were collected manually.

mean collection efficfency for $110 \mathrm{~cm}^{2}$ plastic buckets $=98 \pm 7$

mean collection efficiency for $1233 \mathrm{~cm}^{2}$ plastic buckets $=98 \pm 7$ 
In one experiment a 20 mesh plastic screen was placed over one of the Mckets. The purpose of this screen was to determine the extent of contamination, if any, of the samples by insects.

The results of these studies, shown in Table 2, indicate that dry and wet bucket surfaces collect about the same quantities of either $\mathrm{Na}$ or $\mathrm{Mg}$. The amount of sea salt fallout collected by these two surfaces are always nigher than the amount collected by the Whatman 41 filter. In the experiment where a plastic screen was used, the results show that the bucket with the screen cover collected almost twice as much as either the dry or wet buckets. These findings may be explained as follows: the wet surface was chosen in attempt to simulate the ocean surface. The fact that dry and wet plastic bucket surfaces have approximately the same collection efficiency for sea salt may be due to the hygroscopic nature of sea salt particles which exist as droplets at relative humidity over $70 \%$. It is possible that sea salt particles falling on a dry bucket surface adhere to the side and bottom of the bucket just as well as they when they strike on a wet surface.

Although there is only one datum point for the experiment where a screen cover was used, the higher collection efficiency of the screen surface may be real. This may be because the screen itself acts as an impaction surface or as a filter. As a result of these experiments the choice of a collection surface for dry deposition was limited to a wet or dry plastic bucket surface. However, due to convenience and generally lower blanks, the dry plastic bucket surface was chosen over the wet surface. Also it was noticed that contamination by insects was far less for the dry surface compared to the wet surface. 
Thle 2. Surface collection efficiency for diy fallout and total fallout samples

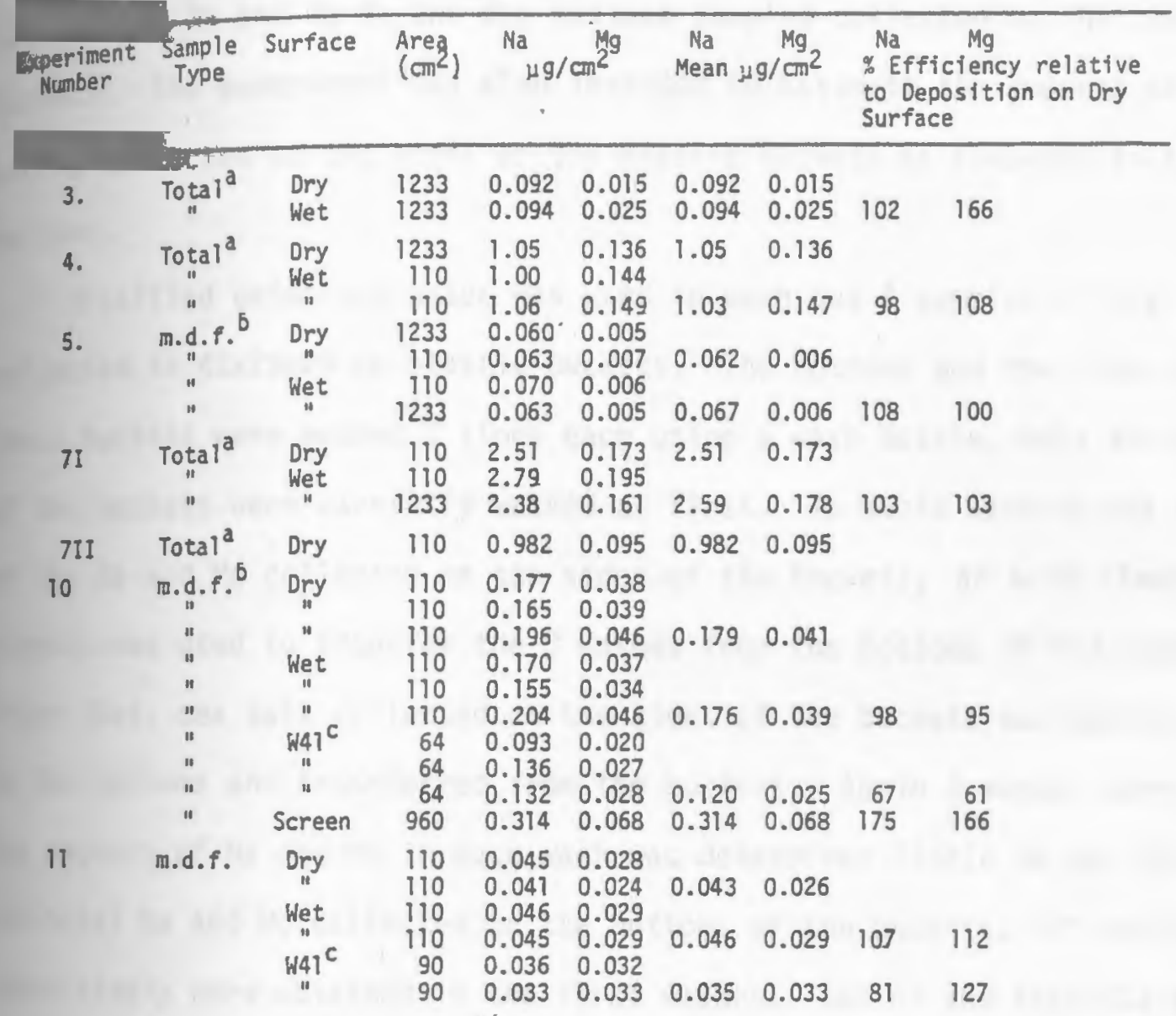

\footnotetext{
Mean EFF. \% wet/dry $=102 \pm 4 \mathrm{Na}$

Mean EFF. $\% W 41 /$ dry $=111 \pm 24 \quad \mathrm{Mg}$

Mean EFF.: W41/dry $=74 \pm 10 \quad \mathrm{Ma}$
}

a = Total fallout (rain and dry fallout).

- Manually collected dry fallout.

c. Whatman 4l filter.

- Samples collected in plastic buckets were obtained by washing the bottom and sides of these buckets. 
c. Dissolution of $\mathrm{Na}$ and $\mathrm{Mg}$ in the dry fallout samples from the
bottom and sides of the plastic buckets This experiment was conducted to determine the number of washes required to wash out $\mathrm{Na}$ and $\mathrm{Mg}$ in the dry fallout samples collected by the plastic buckets. The experiment was also intended to estimate the amounts of $\mathrm{Na}$ and Mg collected on the sides of the plastic buckets as compared to the bottoms.

Distilled deionized water was used to wash out 4 samples of dry fallout collected in $42 \times 29 \times 25 \mathrm{~cm} \mathrm{plastic} \mathrm{buckets.} \mathrm{The} \mathrm{bottoms} \mathrm{and} \mathrm{the} \mathrm{sides} \mathrm{of}$ these buckets were washed 3 times each using a wash bottle, only the bottoms of the buckets were carefully washed at first. To avoid washing out some of the $\mathrm{Na}$ and $\mathrm{Mg}$ collected on the sides of the buckets, an acid cleaned pipette was used to transfer the 3 washes from the bottoms of the buckets. After that, sea salt collected on the sides of the buckets was washed down to the bottoms and transferred from the buckets. Again 3 washes were used. The amounts of $\mathrm{Na}$ and $\mathrm{Mg}$ in each wash was determined (Table $3 \mathrm{a}$ and 3b). of the total $\mathrm{Na}$ and $\mathrm{Mg}$ collected on the bottoms of the buckets, $97 \%$ and $89 \%$ respectively were obtained in the first washes. $86 \%$ of the total Na and $66 \%$ of the total Mg collected on the sides of the buckets were obtained in the first washes, (Table 3b). Essentially all the rest of the $\mathrm{Na}$ on the bottoms and sides of the buckets was removed in the second washes of the buckets. For $\mathrm{Mg}$, three washes were generally required.

Of the total amounts of $\mathrm{Na}$ and $\mathrm{Mg}$ in the fallout samples, $88 \pm 7 \%$ of the $\mathrm{Na}$ and $78 \pm 5 \%$ of the Mg were collected on the bottoms of the plastic buckets (Table $3 a$ and $b$ ). A student $t$-test showed that these numbers are statistically different at a confidence level of $96 \%$. This suggests that particles falling on the sides of the buckets are relatively enriched in 
Table 3a. Dissolution of $\mathrm{Na}$ and $\mathrm{Mg}$ in the ary fallout samples from the bottom

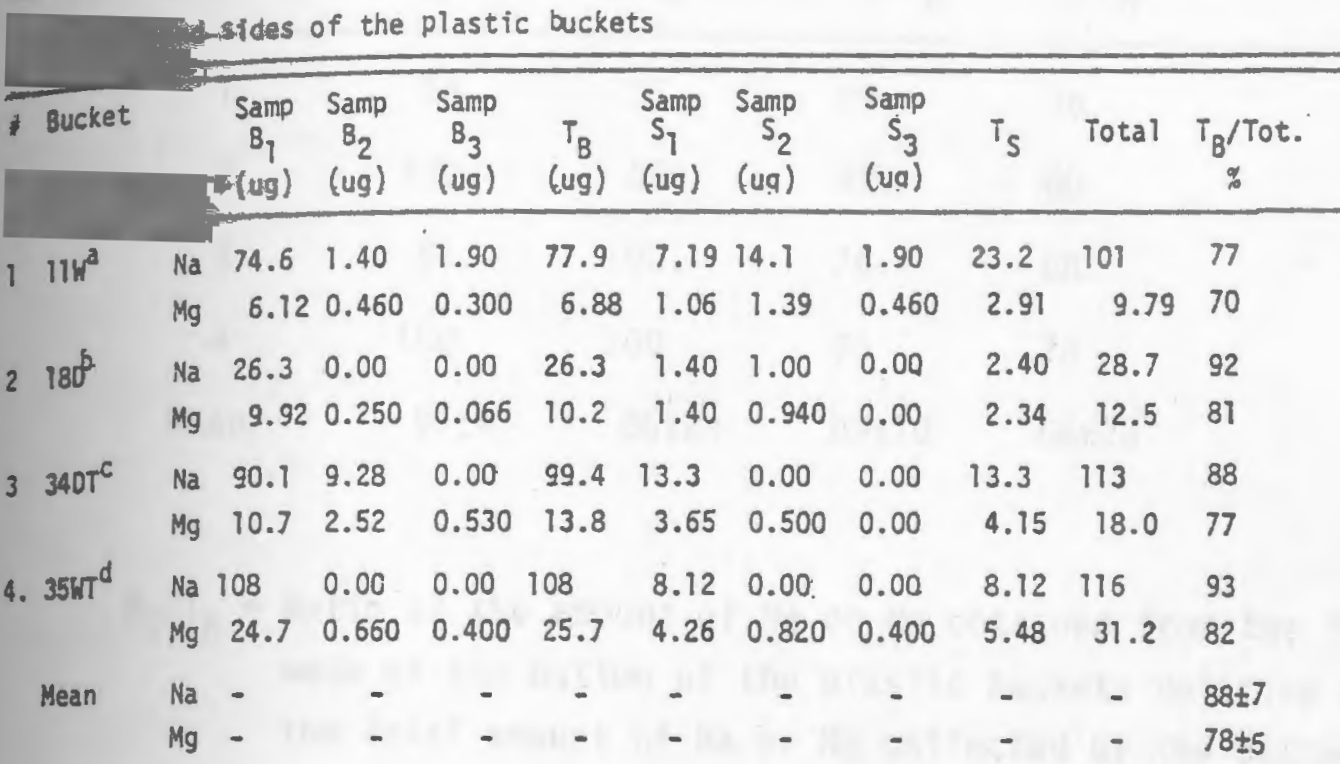

\footnotetext{
a wet bucket

- dry bucket

- dry bucket collected total fallout

$d=$ wet bucket collected total fallout

${ }_{1}, B_{2}, B_{3}=$ bottom of the bucket first wash, second wash, etc.

$S_{1}, S_{2}, S_{3}=$ first wash of the sides of the bucket, second wash of the sides of

$T_{5}=8_{1}+8_{2}+B_{3}$

$T_{S}=S_{1}+S_{2}+S_{3}$

$T_{B} /$ Tot. = ratio of $T_{B}$ to $\left(T_{B}+T_{S} L \times 100\right.$ (percentage)
} 
Table 3b. Proportions of $\mathrm{Na}$ and $\mathrm{Mg}$ in the dry fallout collected on the bottom and sides of the plastic buckets

\begin{tabular}{|c|c|c|c|c|}
\hline \multirow[b]{2}{*}{ Expt. No. } & \multicolumn{2}{|c|}{$\% \mathrm{Na}$} & \multicolumn{2}{|c|}{$\% \mathrm{Mg}$} \\
\hline & ${ }_{B} / T_{B}$ & $\overline{s_{1} / T_{s}}$ & $\overline{B_{1} / T_{B}}$ & $S_{\eta} / T_{B}$ \\
\hline 1 & 96. & 37. & 89. & 36. \\
\hline 2 & 100 & 58. & 97. & 60. \\
\hline 3 & 91. & 100. & 76. & 88. \\
\hline 4 & 100 & 100 & 96 & 78 \\
\hline Mean & $97 \pm 4$ & $86 \pm 24$ & $89 \pm 10$ & $66 \pm 23$ \\
\hline
\end{tabular}

$B_{1} / T_{B}=$ Ratio of the amount of $\mathrm{Na}$ or $M g$ obtained from the first wash of the bottom of the plastic buckets relative to the total amount of $\mathrm{Na}$ or $\mathrm{Mg}$ collected by the bottom of the plastic buckets:

$S_{1} / T_{S}=$ Ratio of the amount of $\mathrm{Na}$ or Mg obtained from the first wash of the sides of the buckets relative to the total amount of $\mathrm{Na}$ or $\mathrm{Mg}$ collected by the sides of the buckets. 
Mg compared with those falling on the bottoms of the buckets. It is possible that some segregation of the falling aerosol particles occurs when they reach the sampling container. Perhaps a higher proportion of the aerosol particles of crustal origin, with their smaller size and higher $\mathrm{Mg} / \mathrm{Na}$ ratio, are preferentially.deposited on the sides of the buckets. Aerosol particles of crustal origin are known to be enriched in Mg relative to $\mathrm{Na}$ as compared to marine aerosols, (Junge, 1963; Riley and Chester, 1971).

In the previous experiment where the collection efficiencies of various surfaces for dry fallout were tested, a Whatman 41 filter surface collected only $74 \%$ as much $\mathrm{Na}$ and $95 \%$ as much $\mathrm{Mg}$ as the dry plastic bucket surface. If we consider that the Whatman 41 filter surface is equivalent only to the bottom of the plastic bucket, one would expect that the Whatman 41 filter would collect about $88 \%$ of the $\mathrm{Na}$ and about $78 \%$ of the $\mathrm{Mg}$ collected by the plastic bucket, assuming the two surfaces had equal collection efficiency. Since these values are approximately equivalent to the actual relative amounts collected by Whatman 41 filter, it seems therefore, the relatively poor collection efficiency of the Whatman 41 filter must be due to the geometry of the collection vessel and not the nature of the filter surface.

d) Efficiency of the automatic rain-dry fallout collector for total deposition

A description of the instrument and the collection efficiency of the containers used in it for rainfall were given earlier in this chapter. The efficiency of the automatic rain-dry fallout collector for total deposition is defined in percent as equal to (total amount of $\mathrm{Na}$ or $\mathrm{Mg}$ in an automatic collector dry fallout sample + total amount of $\mathrm{Na}$ or $\mathrm{Mg}$ in an automatic collector rainfall sample) divided by the total amount of 
$\mathrm{Na}$ or Mg in a manual total fallout sample, all times 100. Four experiments were conducted for this purpose. Replicates of rainfall and dry fallout samples were collected using the automatic rain-dry fallout collector while, during the same period of time, total fallout samples were collected manually using the plastic buckets. The collection efficiency of the automatic samples for total deposition was calculated for $\mathrm{Na}$ and $\mathrm{Mg}$, (Table 4). In experiment 3 and 4, collected during the same rain shower, dry fallout and total fallout samples were collected over two different intervals.

The mean total deposition efficiency was $92 \pm 6 \%$ for $\mathrm{Na}$ and $96 \pm 3 \%$ for $\mathrm{Mg}$. This high efficiency combined with the high collection efficiency for rainfall samples (Table 1 ), make the automatic rain-dry fallout collector an acceptable instrument for convenient and reliable sampling of rainfall and dry fallout samples. Galloway et al. (1976), investigated the collector reliability for rain and dry fallout of several bulk and automated collectors. They found that the automatic rain-dry fallout collector, better known as the U.S. Atomic Energy Commission Collector, was the most reliable of all the automatic collectors investigated. 
4. Efficiency of the automatic rain-Dry fallout collector for total deposition Exp. Automatic Rain Automatic dry fallout Manual total fallout Automatic

No. $\mathrm{Na} \mathrm{Mg} \mathrm{Na} \mathrm{Mg} \mathrm{Na} \mathrm{Mg} \quad \mathrm{Collector}$

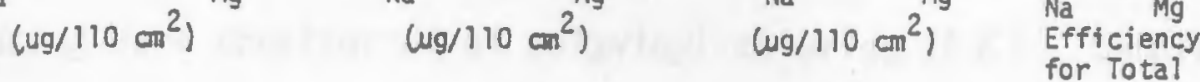
Deposition

135.8

2.50

16.0

10.6

65.5

22.5

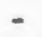

$-11.0$

55.0

21.1

$-\quad 15.0$
$-\quad 10$

10.3

59.0

20.4

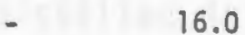

10.2

mean $35.8 \pm 10$

$9.50 \pm 0.95$

$15.7 \pm 5.8 \quad 10.5 \pm 3.6$

$59.7 \pm 5.0$

$21.3 \pm 1.7$

$86 \quad 94$

2125

19.7

13.8

3.00

154

22.8

$-$

- $\quad 17.7$

mean $125 \pm 13$

for 2

$3 \quad 54.2$

$19.7 \pm 7.97$

$15.8 \pm 2.8$

3.00

22.7

$-2$

9.04

43.

$3.00 \pm 0.0 \quad 154 \pm 15$

$22.8 \pm 0$.

$92 \quad 100$

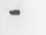

mean $54.2 \pm 5.4$

for 3

$$
73.5
$$

8.20

113

18.3

8.00

$4 \quad 54.2 \pm 5.4$

$9.04 \pm 0.90$

$\begin{array}{lll}75.0 \pm 7.5 & 11.8 \pm 1.2 & 145 \pm 15\end{array}$

$22.3 \pm 2.299 \quad 94$ 


\section{B. Analytical Procedures}

1. Extraction of $\mathrm{Na}$ and $\mathrm{Mg}$ from Whatman 41 Filter

As mentioned previously, atmospheric particulate $\mathrm{Na}$ and $\mathrm{Mg}$ were collected on $20 \times 25 \mathrm{~cm}$ double Whatman 41 cellulose filters. The filter holder and housing were constructed of polyvinyl chloride (PVC). Samples were collected over a period of 24 hours.

In order to dissolve the particulate $\mathrm{Na}$ and $\mathrm{Mg}$ collected on Whatman 41 filters, 3 different procedures were considered. These were 1) sample elution using distilled deionized water or $0.1 \mathrm{~N} \mathrm{HNO}_{3}$ in an ultra-sonic bath; 2) high temperature ashing of the filter at $450-500^{\circ} \mathrm{C}$ using a muffle furnace 3) low temperature ashing of the filter using a LFE model LTA505 low temperature asher. The three techniques were compared as follows:

a. Extraction of known amounts of $\mathrm{Na}$ and $\mathrm{Mg}$ from Whatman 41 filter Using Copenhagen standard sea water, known amounts of $\mathrm{Na}$ and $\mathrm{Mg}$ were added to 3 Whatman 41 filters placed in acid cleaned polyethylene containers. The three filters and two filter blanks were then extracted using $25 \mathrm{ml}$ of $0.1 \mathrm{~N} \mathrm{HNO}_{3}$ in an ultrasonic cleaner for 5 minutes. Results, shown in Table 5 , indicate that the ultrasonic extraction procedure was $100 \%$ efficient in recovering soluble $\mathrm{Na}$ and $\mathrm{Mg}$. The extractable blank for Whatman 41 filters was $0.091 \mu \mathrm{g} \mathrm{Na} / \mathrm{cm}^{2}$ and $0.014 \mu \mathrm{g} \mathrm{Mg} / \mathrm{cm}^{2}$.

b. Ultrasonic extraction versus high temperature ashing

To compare the efficiency of the ultrasonic extraction technique to the high temperature ashing method, 3 dry fallout samples collected on Whatman 41 filters and one filter blank were studied. Using clean stainless-steel surgical scissors and a laminar flow clean bench, each of the 4 filters were cut into 2 equal halves. Disposable polyethylene 
Table 5. Extraction of known amounts of $\mathrm{Na}$ and $\mathrm{Mg}$ from a Whatman 41 filter using $0.1 \mathrm{~N} \mathrm{HNO}_{3}$ acid and an ultrasonic cleaner

\begin{tabular}{lcccccc} 
Sample & $\begin{array}{r}\text { ug Na } \\
\text { added }\end{array}$ & $\begin{array}{c}\text { ug Na } \\
\text { added }\end{array}$ & $\begin{array}{c}\text { ug } \\
\text { found }\end{array}$ & $\begin{array}{c}\text { ug Mg } \\
\text { added }\end{array}$ & $\begin{array}{c}\% \mathrm{EFF} \\
\mathrm{Na}\end{array}$ & $\begin{array}{c}\% \text { EFF } \\
\mathrm{Mg}\end{array}$ \\
\hline 131 & Blank & Blank & $0.091 \mathrm{~cm}^{-2}$ & $0.014 \mathrm{~cm}^{-2}$ & - & - \\
132 & 1 & 4 & $0.091 \mathrm{~cm}^{-2}$ & $0.014 \mathrm{~cm}^{-2}$ & - & - \\
134 & 8.62 & 1.04 & 8.70 & 1.08 & 101 & 104 \\
135 & 4.31 & 0.52 & 4.45 & 0.53 & 103 & 102 \\
136 & 2.59 & 0.31 & 2.58 & 0.50 & 100 & $161^{*}$
\end{tabular}

*Possible Mg contamination

$\mathrm{Na}$ and Mg blanks were subtracted from samples 134, 135 and 136 . 
gloves were worn during the cutting and handling of the filters. One half of each filter was then extracted using $0.1 \mathrm{~N} \mathrm{HNO}_{3}$ in an ultrasonic bath while the other half was ashed at $450-500^{\circ} \mathrm{C}$ in a muffle furnace for 15 hours. A clean $100 \mathrm{ml}$ pyrex beaker with a watch glass was used for this purpose. After ashing, the contents of the beaker were dissolved with a combination of suprapur $\mathrm{HCl}$ and $\mathrm{HNO}_{3}$, of concentrations $12 \mathrm{~N}$ and $16 \mathrm{~N}$ respectively. The results (Table 6 ), show that the amount of $\mathrm{Na}$ and Mg obtained by the two dissolution procedures are comparable in the three samples analysed. The differences are within the analytical error. If we consider that the $\mathrm{Na}$ and $\mathrm{Mg}$ blanks obtained by high temperature ashing represent the total blank values and the ones obtained by ultra-sonic extraction represent only the extractable blanks in Whatman 41 filter, then it appears that the extractable $\mathrm{Na}$ blank amounts to only $1 / 3$ of the total $\mathrm{Na}$ blank and the extractable $\mathrm{Mg}$ blank is equivalent to about $3 / 4$ of the total Mg blank. Hoffman et al. (1972) compared dry ashing with extraction techniques for atmospheric particulate $\mathrm{Na}$ collected on Delbag polystyrene filters. They found that the two techniques have essentially the same dissolution efficiency.

c. Extraction of particulate $\mathrm{Na}$ and $\mathrm{Mg}$ from Whatman 41 filter samples using $0.1 \mathrm{~N} \mathrm{HNO}_{3}$ and distilled deionized water.

Hoffman (1969) used $0.1 \mathrm{~N} \mathrm{HNO}_{3}$ and $3 \mathrm{~N} \mathrm{HNO}_{3}$ to extract particulate $\mathrm{Pb}$ from equal portions of glass fiber filters. She found that filters axtracted ultrasonically with $3 \mathrm{~N} \mathrm{HNO}_{3}$ contained more $\mathrm{Pb}$ than those extracted with $0.1 \mathrm{~N} \mathrm{HNO}_{3}$. That was due to the higher blanks of the glass fiber filters when eluted with $3 \mathrm{~N} \mathrm{HNO}_{3}$. She also found that the ultrasonic cleaner reached a maximum efficiency after 5 minutes. 
Table 6. Extraction of $\mathrm{Na}$ and $\mathrm{Mg}$ from Whatman 41 filters using high temperature ashing and extraction with $0.1 \mathrm{~N} \mathrm{HNO}_{3}$ in an ul trasonic b ath.

Sample No.

$\frac{u \mathrm{gNa} / \mathrm{cm}^{2} \quad \mathrm{ugMg} / \mathrm{cm}^{2}}{\text { Uitrasonic Extraction }} \quad \frac{\mathrm{ugNa} / \mathrm{cm}^{2} \quad \mathrm{ugMg} / \mathrm{cm}^{2}}{\text { High Temperature Ashing }}$

$\begin{array}{lllll}* \mathrm{~B}_{1} & 0.088 & 0.009 & 0.272 & 0.012 \\ +S_{1} & 0.467 & 0.023 & 0.483 & 0.030 \\ +S_{2} & 1.05 & 0.037 & 0.710 & 0.027 \\ +S_{3} & 0.029 & 0.010 & 0.027 & 0.013\end{array}$

* Whatman 41 filter blank

+ Dry fallout samples, blank subtracted 
In the present study distilled deionized water was compared to $0.1 \mathrm{~N} \mathrm{HNO}_{3}$ as solvent for ultrasonic extraction of particulate $\mathrm{Na}$ and $\mathrm{Mg}$ from Whatman 41 filters. Extractions were carried out for different time intervals to determine the time required before the ultrasonic cleaner reached the maximum efficiency.

In this experiment a $20 \times 25 \mathrm{~cm}$ double Whatman 41 filter blank and two atmospheric particulate samples, \#14 and 15, were each cut diagonally into 8 equal sections. Selected alternatively, 4 sections of the filter blank and of each of the two samples were extracted with distilled deionized water in an ultrasonic cleaner for different time intervals. The same procedure was repeated with the other 4 sections using $0.1 \mathrm{~N} \mathrm{HNO}_{3}$ acid. After being extracted, 2 sections of the filter blank and 4 sections of each of the two sample filters were then low temperature ashed to determine the efficiency of the ultrasonic extraction. The filters were ashed at an oxygen flow of $50 \mathrm{cc} / \mathrm{min}$ and a radio-frequency (RF) power of 50 watts for 24 hours. The residue was then taken up in $0.5 \mathrm{ml}$ of concentrated Suprapur HF acid to which was added $0.5 \mathrm{ml}$ of concentrated, distilled $\mathrm{HNO}_{3}$ acid. The solution was then transferred to a precleaned $7 \mathrm{ml}$ polyethylene vial. The vial was left to stand for 2 weeks and prior to analysis $5 \mathrm{ml}$ of distilled deionized $\mathrm{H}_{2} \mathrm{O}$ was added to make the acid content $\sim 1.6 \mathrm{~N} \mathrm{HNO}_{3}$ and $2 \mathrm{~N} \mathrm{HF}$.

The results of the blank filter study, shown in Table 7 , indicate that there may be some tendency for the extractable $\mathrm{Na}$ blank to increase with increase in extraction time interval. This trend was more obvious when distilled deionized water was used as a solvent. At an extraction time interval of 7 minutes the $\mathrm{Na}$ blank was almost twice the one obtained 
Table 7. Extraction of particulate $\mathrm{Na}$ and $\mathrm{Mg}$ from a Whatman 41 filter blank using $0.1 \mathrm{~N} \mathrm{HMO}_{3}$ and $\mathrm{O} . \mathrm{O} . \mathrm{H}_{2} \mathrm{O}$ and an ul trasontc bath.

\begin{tabular}{|c|c|c|c|c|c|c|c|}
\hline $\begin{array}{l}\text { Wha tman } \\
\text { Biank }\end{array}$ & $\begin{array}{l}41 \\
\text { Section } \\
\text { No. }\end{array}$ & Solvent & $\begin{array}{l}\text { Time } \\
\text { Min }\end{array}$ & $\begin{array}{l}\text { g Na cm} \\
\text { Extracted }\end{array}$ & $\begin{array}{c}9 \mathrm{Mg} \mathrm{cm}^{-2} \\
\text { Extracted }\end{array}$ & $\underset{A \operatorname{Na~} \mathrm{cm}^{-2}}{\operatorname{Ashed}(L . T . A .)}$ & $\begin{array}{l}\text { ig } \mathrm{Mg} \mathrm{cm} \mathrm{cm}^{-2} \\
\text { ) After Extraction }\end{array}$ \\
\hline & 1 & $0.1 \mathrm{NHNO}_{3}$ & 1 & 0.055 & 0.010 & - & - \\
\hline & 3 & $"$ & 3 & 0.049 & 0.008 & - & - \\
\hline & 5 & $"$ & 5 & 0.105 & 0.008 & 0.280 & 0.162 \\
\hline & 7 & $"$ & 7 & 0.080 & 0.008 & - & $\sqrt{2}+x_{0}$ \\
\hline \multirow{2}{*}{\multicolumn{2}{|c|}{ Mean }} & - & & 0.072 & 0.009 & 0.280 & 0.162 \\
\hline & & & & \pm 0.026 & \pm 0.001 & \pm 0.03 & \pm 0.02 \\
\hline & 2 & O.D. $\mathrm{H}_{2} \mathrm{O}$ & 1 & 0.043 & 0.006 & - & - \\
\hline & 4 & $"$ & 3 & 0.049 & 0.005 & 0.139 & 0.002 \\
\hline & 6 & $"$ & 5 & 0.075 & 0.006 & - & - \\
\hline & 8 & $"$ & 7 & 0.087 & 0.008 & - & - \\
\hline \multirow{2}{*}{\multicolumn{2}{|c|}{ Mean }} & - & & 0.064 & 0.006 & 0.139 & 0.002 \\
\hline & & & & \pm 0.021 & \pm 0.001 & \pm 0.01 & \\
\hline \multirow{2}{*}{\multicolumn{2}{|c|}{$\begin{array}{l}\text { mean }\left(\mathrm{H}_{2} \mathrm{O}\right) \\
\left.+0.1 \mathrm{~N} \mathrm{HNO}_{3}\right)\end{array}$}} & & & 0.068 & 0.008 & 0.139 & 0.002 \\
\hline & & & & \pm 0.022 & \pm 0.002 & \pm 0.01 & \\
\hline
\end{tabular}


at 1 minute time interval. This trend was not observed for the $\mathrm{Mg}$ blank. It appears that the extractable Mg blank is independent of the extraction time intervals for the two solvents used. This suggests that the ultrasonic cleaner reaches a maximum efficiency after only one minute in the case of Mg blank.

If we add the mean of extractable blank to the mean of the ashed blank (Table 7), the total blank for Whatman 41 filter becomes 0.207 ug $\mathrm{Na} / \mathrm{cm}^{2}$ and $0.010 \mu \mathrm{g} \mathrm{gg} / \mathrm{cm}^{2}$. These blank values are comparable to the values obtained by high temperature ashing alone (Table 6).

Dams et al. (1972) obtained $0.150 \mathrm{Mg} \mathrm{Na} / \mathrm{cm}^{2}$ and $20.08 \mathrm{ug} \mathrm{Mg} / \mathrm{cm}^{2}$ blank values for Whatman 41 filters. This last figure is considerably higher than found here. E. Hoffman (personal communication) found that the $\mathrm{Mg}$ blank in Whatman 41 filter was $20.018 \mu \mathrm{g} / \mathrm{cm}^{2}$.

As seen from the data in Table 7, 8 and 9, the extractable $\mathrm{Na}$ and $\mathrm{Mg}$ blanks amount to only $8 \%$ and $4 \%$ respectively of the extractable $\mathrm{Na}$ and $\mathrm{Mg}$ collected by sample filter 14, while for sample 15 they comprise only $3 \%$ of the total extractable $\mathrm{Na}$ or $\mathrm{Mg}$. Since these figures are within the sampling and analytical error it was not possible to observe any effect of increased extraction time on the amount of $\mathrm{Na}$ recovered in sample 14 and 15 . The results also confirm that distilled deionized water is as efficient a solvent as $0.1 \mathrm{~N} \mathrm{HNO}_{3}$ for dissolving sea salt collected on Whatman 41 cellulose filters.

Out of the $50 \mathrm{ml}$ of $\mathrm{H}_{2} \mathrm{O}$ used to extract particulate $\mathrm{Na}$ and $\mathrm{Mg}$ from Whatman 41 filters, approximately $88 \%$ is recovered, the rest remaining in the filter. Taking this into consideration and using the mean amount of $\mathrm{Na}$ and $\mathrm{Mg}$ recovered from sample filters \#14 and 15 the data in Tables 
Table 8. Extraction of particulate $\mathrm{Na}$ and $\mathrm{Mg}$ from atmospheric particulate sample No. 14. (Biank subtracted)

\begin{tabular}{|c|c|c|c|c|c|c|c|}
\hline $\begin{array}{l}\text { Sample } \\
14\end{array}$ & $\begin{array}{l}\text { No. } \\
\text { Section } \\
\text { No. }\end{array}$ & Solvent & $\begin{array}{l}\text { Time } \\
\text { Min }\end{array}$ & $\begin{array}{l}\text { yg } \mathrm{Na} / \mathrm{cm}^{2} \\
\text { Extracted }\end{array}$ & $\begin{array}{l}\mu g \mathrm{Mg} / \mathrm{cm}^{2} \\
\text { Extracted A }\end{array}$ & $\begin{array}{l}\text { Ng } \mathrm{Na} / \mathrm{cm}^{2} \\
\text { Ashed(L.T.A.) }\end{array}$ & $\begin{array}{c}\mu \mathrm{Mg} / \mathrm{cm}^{2} \\
\text { After Extraction }\end{array}$ \\
\hline & 1 & $0.1 \mathrm{NHO}_{3}$ & 1 & 0.795 & 0.190 & - & - \\
\hline & 3 & $"$ & 3 & 0.872 & 0.215 & 0.250 & 0.232 \\
\hline & 5 & $"$ & 5 & 0.770 & 0.193 & & \\
\hline & 7 & $"$ & 7 & 0.790 & 0.205 & 0.180 & 0.232 \\
\hline & Mean & - & & 0.807 & 0.201 & 0.215 & 0.232 \\
\hline & & & & \pm 0.045 & \pm 0.012 & \pm 0.049 & \pm 0.023 \\
\hline & 2 & $\mathrm{DD} \mathrm{H}_{2} \mathrm{O}$ & 1 & 0.787 & 0.178 & 0.165 & 0.236 \\
\hline & 4 & $"$ & 3 & 0.800 & 0.203 & - & \\
\hline & 6 & $"$ & 5 & 0.824 & 0.185 & $0.404^{\star}$ & $0.418^{\star}$ \\
\hline & 8 & " & 7 & 0.816 & 0.192 & - & - \\
\hline & Mean & - & & 0.807 & 0.190 & 0.165 & 0.236 \\
\hline & & & & \pm 0.017 & \pm 0.011 & \pm 0.017 & \pm 0.024 \\
\hline \multirow{2}{*}{\multicolumn{2}{|c|}{$\begin{array}{l}\operatorname{mean}\left(\mathrm{H}_{2} \mathrm{O}\right) \\
\left.+0.1 \mathrm{~N} \mathrm{HNO}_{3}\right)\end{array}$}} & & & 0.807 & 0.195 & 0.198 & 0.233 \\
\hline & & & & \pm 0.03 & \pm 0.01 & \pm 0.05 & \pm 0.002 \\
\hline
\end{tabular}

* Possible contamination. Values not used when means calculated. 
Tabie 9. Extraction of particulate $\mathrm{Na}$ and $\mathrm{Mg}$ from atmospheric particulate sample

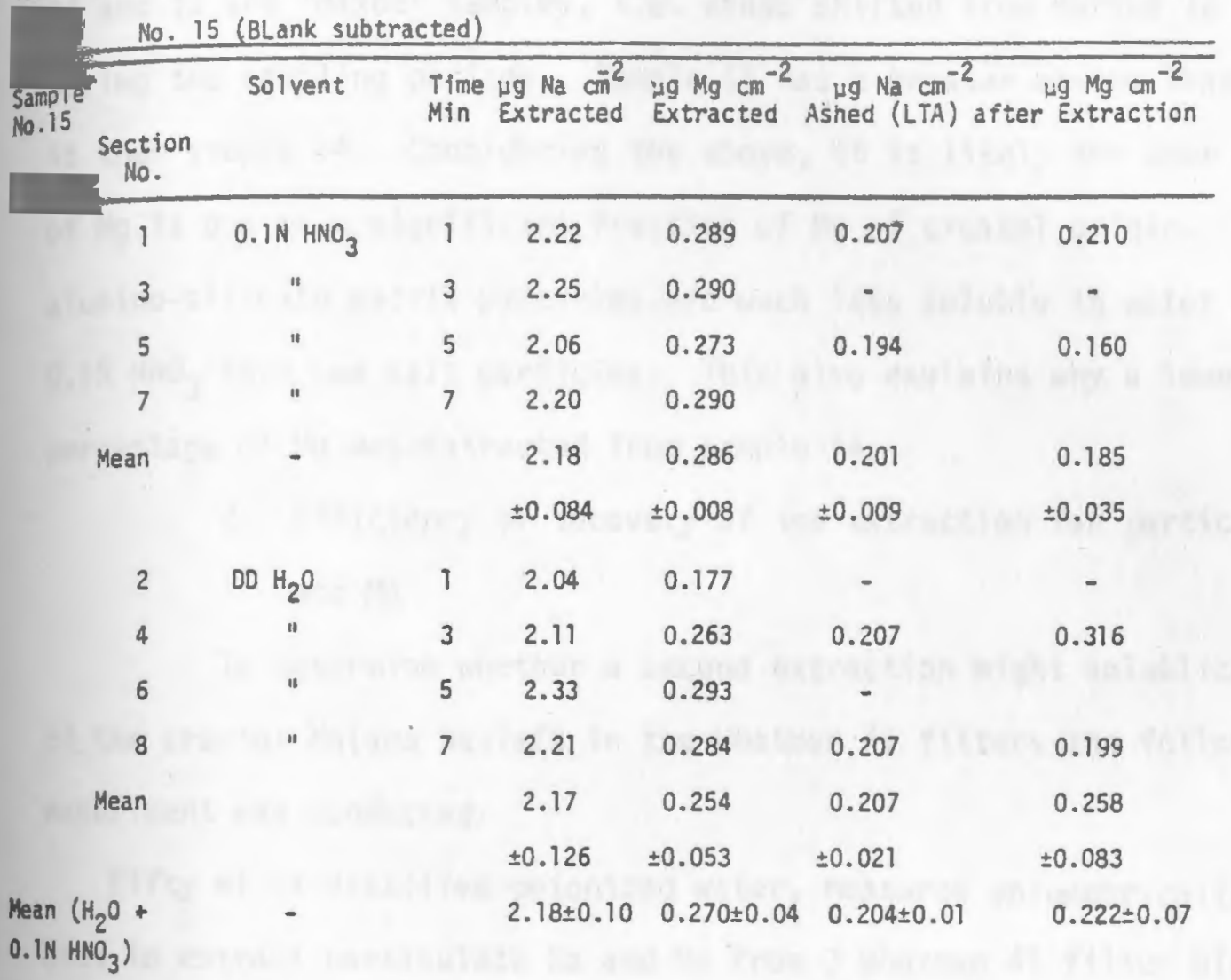


8 and 9 indicate that ultrasonic extraction is essentially $100 \%$ efficient for removing $\mathrm{Na}$ but only 50-60\% efficient for $\mathrm{Mg}$.

Meteorological data compiled during sampling indicate that sample 14 and 15 are "mixed" samples, i.e. winds shifted from marine to land during the sampling periods. Sample 15 has a greater marine fraction in it than sample 14. Considering the above, it is likely the poor extraction of $\mathrm{Mg}$ is due to a significant fraction of Mg of crustal origin. These alumino-silicate matrix particles are much less soluble in water and $0.1 \mathrm{~N} \mathrm{HNO}_{3}$ than sea salt particles. This also explains why a lower percentage of $\mathrm{Mg}$ was extracted from sample 14.

d. Efficiency of recovery of one extraction for particulate $\mathrm{Na}$ and $\mathrm{Mg}$

To determine whether a second extraction might solublize more of the crustal $\mathrm{Mg}$ (and $\mathrm{Na}$ ) left in the Whatman 41 filters the following experiment was conducted.

Fifty $\mathrm{ml}$ of distilled deionized water, measured volumetrically, was used to extract particulate $\mathrm{Na}$ and $\mathrm{Mg}$ from 3 Whatman 41 filter blanks and duplicates of 4 atmospheric samples. The blanks and sample were quarters of $20 \times 25 \mathrm{~cm}$ double Whatman 41 cellulose filters. The extraction was carried out for 2 minutes using an ultrasonic cleaner. The volume of extract recovered was determined by weight. Then another $10 \mathrm{ml}$ of distilled deionized water was used to re-extract the filters in order to determine the efficiency of the first extraction. Again the volume recovered was determined by weight. The results (Table 10), were presented as percent recovery of the volume of solvent used and of the $\mathrm{Na}$ and $\mathrm{Mg}$ recovered from the first extraction. As shown, the percentage of 
Tabie 10. Efficiency of extraction of atmospheric Na and Mg from Whatman 41 filter using an ultrasonic cleaner and $\mathrm{DD} \mathrm{H}_{2} \mathrm{O}$.

Sample No. \% of total $\mathrm{H}_{2} \mathrm{O} \quad \%$ of total Na \% of total Mg recovered on first recovered on first recovered on first extract extract extract

$\begin{array}{clll}\text { Blank } 500 & 87 & 77 & 73 \\ \text { " } 501 & 85 & 79 & - \\ \text { mean (blank) } & 85 \pm 1.5 & 77 & 68 \\ 23 \mathrm{~A} & 88 & 78 \pm 1.2 & 71 \pm 3.5 \\ 23 \mathrm{~B} & 87 & 87 & 84 \\ 24 \mathrm{~A} & 88 & 87 & 83 \\ 24 \mathrm{~B} & 88 & 87 & 82 \\ 26 \mathrm{~A} & 88 & 86 & 82 \\ 26 \mathrm{~B} & 88 & 86 & 83 \\ 27 \mathrm{~A} & 91 & 86 & 83 \\ 27 \mathrm{~B} & 91 & 91 & 90 \\ \text { mean } & 89 \pm 1.5 & 89 & 84 \pm 3.0\end{array}$


the $\mathrm{Na}$ and $\mathrm{Mg}$ recovered is very close to the percentage of the volume of water recovered after the first extraction. This result suggests that one extraction is sufficient to obtain all the soluble $\mathrm{Na}$ and $\mathrm{Mg}$ collected on the Whatman 41 filters, if the volume of water remaining in the filter after extraction taken into consideration.

Atmospheric particulate samples collected on Whatman 41 filters for this project were therefore extracted ultrasonically only once using $50 \mathrm{ml}$ of distilled deionized water. The amounts of $\mathrm{Na}$ and $\mathrm{Mg}$ recovered were calculated on the basis of the total volume of solvent used.

2. Sample Analysis

a. Atomic absorption

Dry fallout, rainfall and total fallout samples were analysed for $\mathrm{Na}$ and $\mathrm{Mg}$ using Perkin Elmer Atomic Absorption Spectrophotometer Mo dels 360 and 303. Acetylene-air flame atomic absorption procedures were used. Depending on the concentration range of samples, burner heads of sizes 1", 2" and 4" with one or three slots were used. Burner heads were sometimes turned at $45^{\circ}$ or $90^{\circ}$, depending on the concentration of the samples, so as to remain within the linear region of atomic absorption. Perkin-Elmer Intensitron lamps were used, and wavelengths of $589 \mathrm{~nm}$ for $\mathrm{Na}$ and $285 \mathrm{~nm}$ for Mg were utilized. During analysis standards were prepared every other day from Copenhagen standard sea water, of salinity equal to $35 \%$. This corresponds to a $\mathrm{Na}$ concentration of $10772 \mathrm{ppm}$ and a Mg concentration equal to $1297 \mathrm{ppm}$ ( $\mathrm{R}$. Pytkowicz and D. R. Kester 1971).

Typical calibration curves for $\mathrm{Na}$ and $\mathrm{Mg}$ are given in Figures 3-4. Calibration curves used in determining unknown concentrations were computed 
Figure 3. A typical calibration curve of $\mathrm{Na}$ aconcentration versus absorbance, with burner head rotated at $90^{\circ}$. 


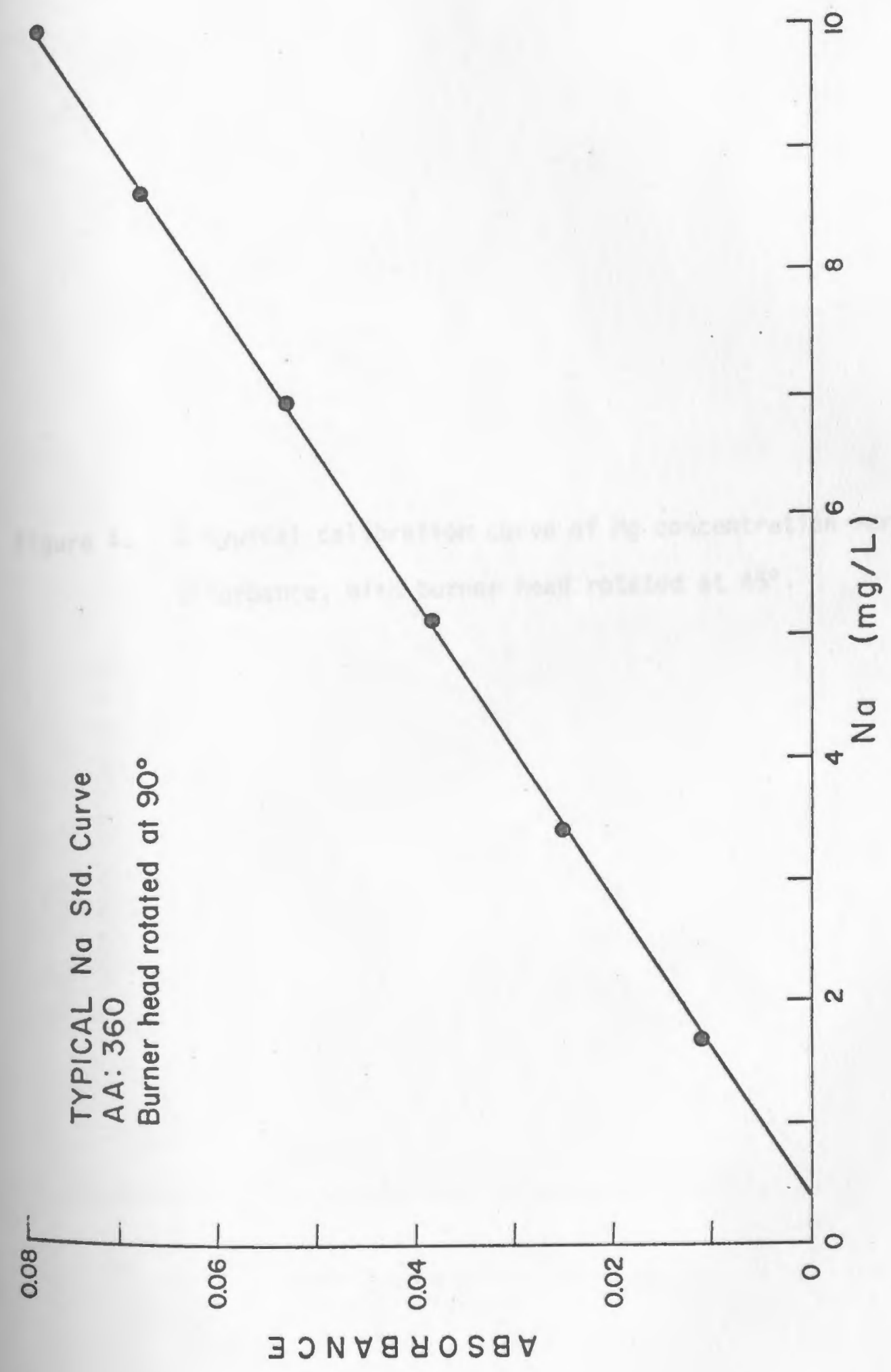


Figure 4. A typical calibration curve of Mg concentration versus absorbance, with burner head rotated at $45^{\circ}$. 


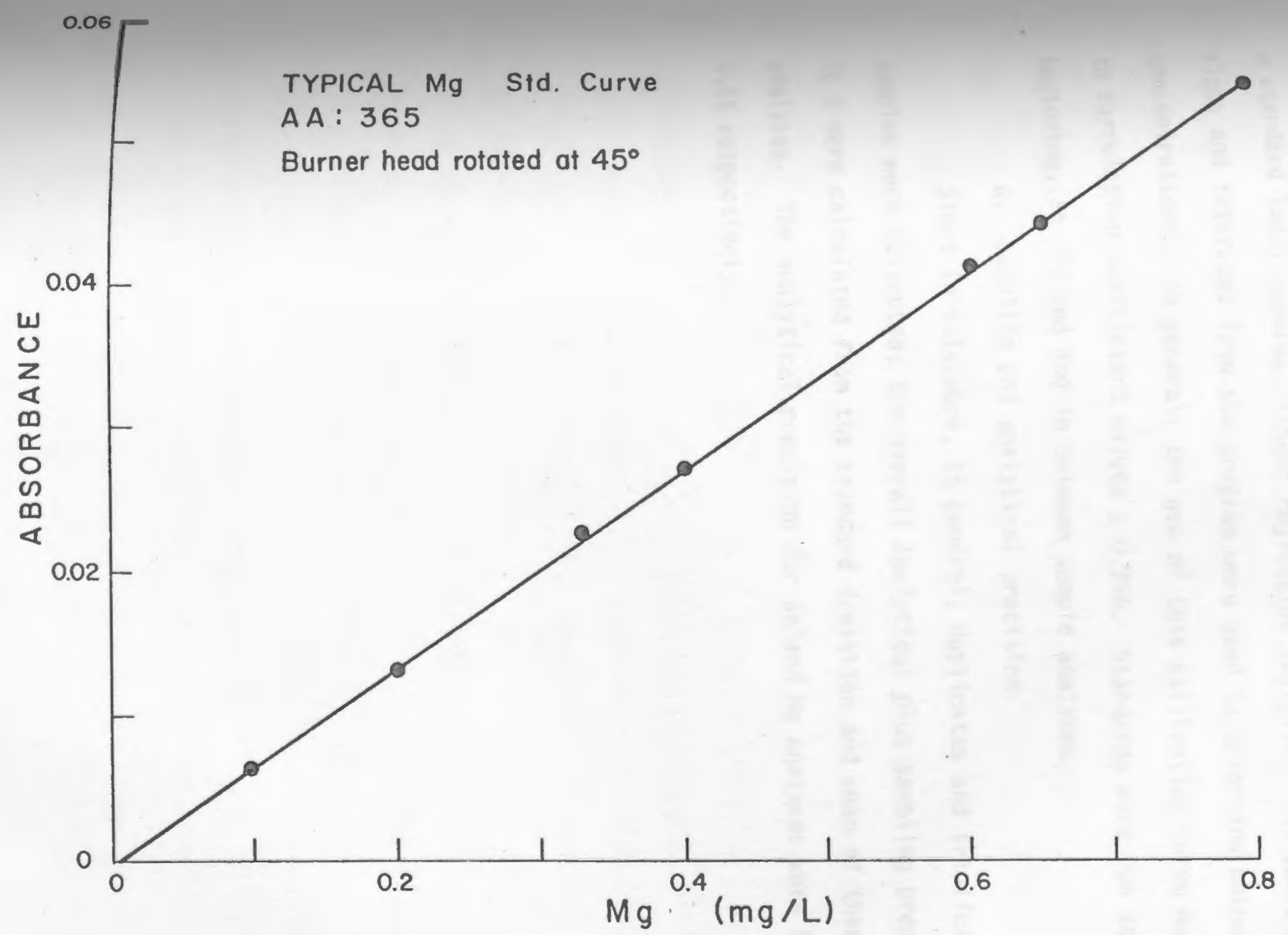


using a Texas Instrument SR-51-II Electronic Calculator programmed for a standard least squares, linear regression analysis. The computed slope and intercept from the program were used to determine unknown concentrations. In general, the use of this calibration curve was restricted to correlation coefficient values $\geq 0.996$. Standards were run at the beginning, at the end and in between sample analyses.

b. Sampling and analytical precision

Since in this work, in general, duplicates and triplicates of samples were collected, the overall analytical plus sampling precision. in $\%$ were calculated from the standard deviation and mean of these replicate analyses. The analytical precision for $\mathrm{Na}$ and $\mathrm{Mg}$ analyses were $5.7 \%$ and $5.4 \%$ respectively. 
III. RESULTS

\section{A. General Considerations}

The results of the analyses of dry fallout, rain and atmospheric particulate samples collected in this study are given in Table 12-22. Except for samples 3,4,5,6 and 10 and samples collected aboard RV/Trident (Table 18), all samples were collected over a 24 hour period continually from April 15 to June 28, 1976. Samples collection information is shown on Table II.

\section{B. Classification of Samples}

After studying the meteorological data compiled during sampling, dry fallout, rainfall and atmospheric samples were divided into 3 different categories depending on the local surface wind direction during the sampling period (Fig. 5). Samples collected while the wind direction was between $090^{\circ}$ and $230^{\circ}$ were considered "marine" samples and were designated S.Samples collected within the sector $230^{\circ}-010^{\circ}$ were considered "land" samples and were designated L. Samples collected while the wind was blowing from near the boundary between the land and marine sectors and/or where the wind direction shifted from the marine to the 1 and sector or vice versa were considered "mixed" samples and were designated $S \Lambda$. To this category, samples collected within the sector $010^{\circ}-090^{\circ}$ were also included. These 3 different sets of samples could be considered to represent 3 different meteorological subenvironments of the coastal Rhode Island environment depending on the local wind conditions

1. Atmospheric Concentrations and Dry Deposition

a. Coastal Rhode Island

i)"Marine", "Mixed"and "Land" Samples

The rate of dry fallout for $\mathrm{Na}$ and $\mathrm{Mg}$, the $\mathrm{Mg} / \mathrm{Na}$ ratios, the 
Table 11. Samples collection information

$\begin{array}{lcc}\text { Experi- } & \text { Sample } & \text { Sample type } \\ \text { ment No. } & \text { No. } & \end{array}$

Date of Collection Volume ${ }^{+}$ collection time(hours) of air

$\left(\mathrm{m}^{3}\right)$

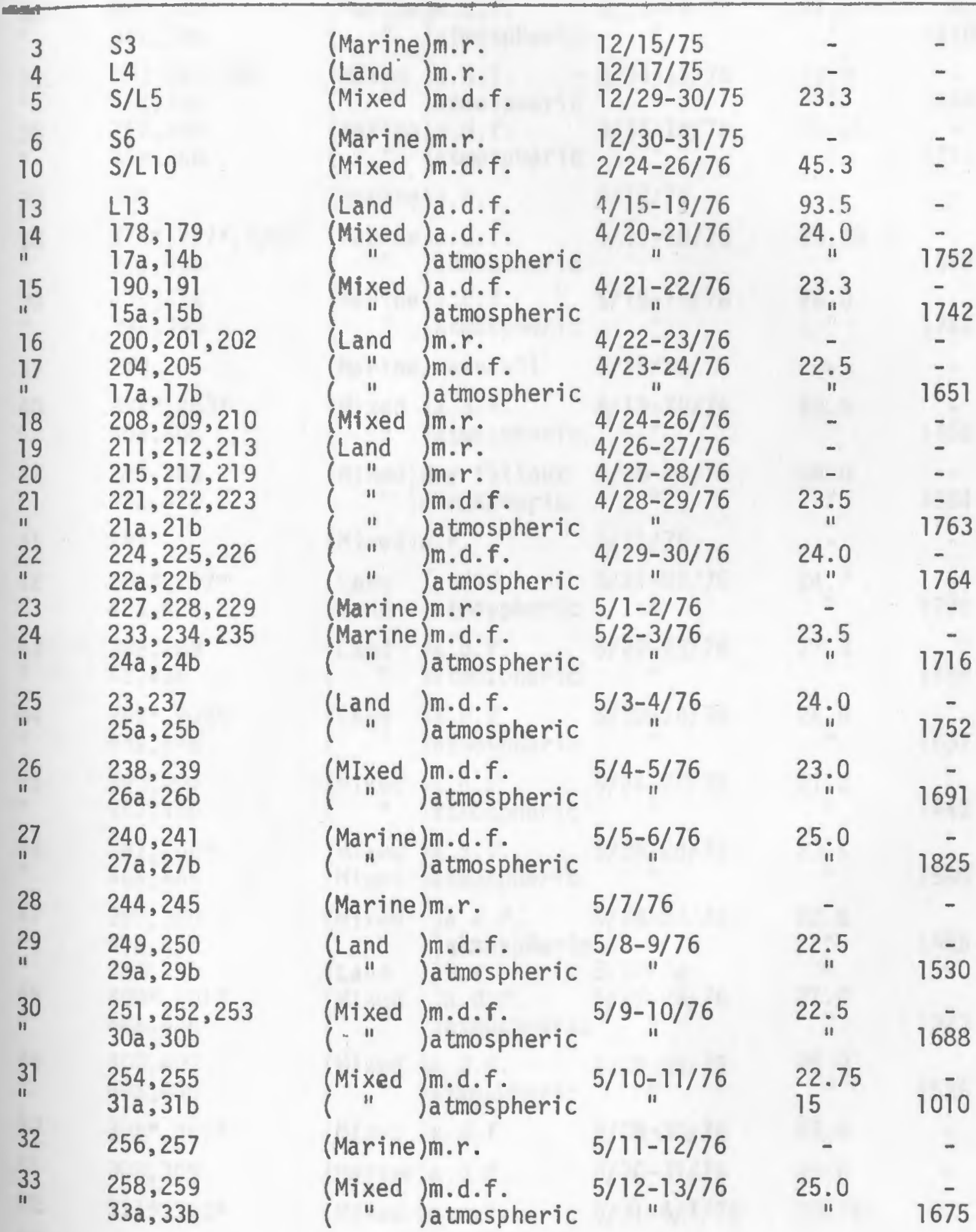


Table 11 (Continued)

Experi- Sample Sample Type ment No. No.

Date of Collection Volume+ collection time(hours) of ajr (hours)

\begin{tabular}{|c|c|c|c|c|c|}
\hline 34 & $\begin{array}{l}260,261 \\
342,34 b\end{array}$ & $\begin{array}{l}\text { (Marine)m.d.f. } \\
\text { (") atmospheric }\end{array}$ & $5 / 13-14 / 76$ & 21.5 & $15 \overline{0}$ \\
\hline 35 & $\begin{array}{l}262,263,265 \\
352,35 b\end{array}$ & $\left(\begin{array}{l}\text { Mixed }) \text { a.d.f. } \\
\text { atmospheric }\end{array}\right.$ & $\underset{11}{5 / 14-15 / 76}$ & 23.0 & $15 \overline{54}$ \\
\hline 36 & $\begin{array}{l}267,268 \\
36 a, 36 b\end{array}$ & $\begin{array}{l}\text { (Marine)a.d.f. } \\
\text { (" )atmospheric }\end{array}$ & $\underset{11}{5 / 75-16 / 76}$ & 25.25 & $17 \overline{9}$ \\
\hline 37 & 266 & (Marine)a.r. & $5 / 17 / 76$ & - & - \\
\hline 38 & $\begin{array}{l}274^{*}, 277^{*}, 278^{*} \\
38 a, 38 b\end{array}$ & (Marine)a.d.f. & $5 / 17-18 / 76$ & 20.25 & $1 \overline{37}$ \\
\hline $\begin{array}{l}39 \\
\text { " }\end{array}$ & $\begin{array}{l}275,276 \\
392,39 b\end{array}$ & $\begin{array}{l}\text { (Marine)a.d.f. } \\
\text { (") atmospheric }\end{array}$ & 5/18-19/76 & 26.0 & $1 \overline{4} \overline{2}$ \\
\hline 39 & 273 & (Marine)rainfall & $5 / 19 / 76$ & - & - \\
\hline $\begin{array}{l}40 \\
11\end{array}$ & $\begin{array}{l}282 *, 283 * \\
40 a, 40 b\end{array}$ & $\begin{array}{l}\text { (Mixed ) a.d.f. } \\
\text { (" ) atmospheric }\end{array}$ & $\underset{11}{5 / 19-20 / 76}$ & 20.5 & $14 \overline{56}$ \\
\hline $\begin{array}{l}41 \\
11\end{array}$ & $\begin{array}{l}284,285 \\
41 a, 41 b\end{array}$ & $\begin{array}{l}\text { (Mixed) dry fallout } \\
\text { " }) \text { atmospheric }\end{array}$ & $\begin{array}{c}5 / 20-21 / 76 \\
11\end{array}$ & 24.0 & $15 \overline{8}$ \\
\hline 41 & 281 & (Mixed)a.r. & $5 / 21 / 76$ & - & - \\
\hline $\begin{array}{l}42 \\
11\end{array}$ & $\begin{array}{l}286^{\star}, 287^{\star} \\
42 \mathrm{a}, 42 \mathrm{~b}\end{array}$ & $\begin{array}{l}\text { (Land )a.d.f. } \\
\text { (Land )atmospheric }\end{array}$ & $5 / 21-22 / 76$ & 24.7 & $17 \overline{7}$ \\
\hline $\begin{array}{l}43 \\
11\end{array}$ & $\begin{array}{l}288,289 \\
42,43 b\end{array}$ & 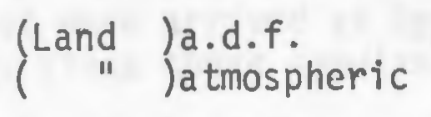 & $\begin{array}{c}5 / 22-23 / 76 \\
\text { II }\end{array}$ & 23.3 & 1584 \\
\hline $\begin{array}{l}44 \\
1 "\end{array}$ & $\begin{array}{l}291 *, 292^{*} \\
44 a, 44 b\end{array}$ & $\begin{array}{l}\text { (Land } \text { "a.d.f. } \\
\text { atmospheric }\end{array}$ & $\underset{11}{5 / 23-24 / 76}$ & 24.8 & 1637 \\
\hline $\begin{array}{l}45 \\
11\end{array}$ & $\begin{array}{l}293,294 \\
452,45 b\end{array}$ & $\begin{array}{l}\text { (Mixed ) a.d.f. } \\
\text { (" }) \text { atmospheric }\end{array}$ & $\begin{array}{c}5 / 24-25 / 76 \\
\text { " }\end{array}$ & $2 i_{i}^{2}$ & 1442 \\
\hline $\begin{array}{l}46 \\
11\end{array}$ & $\begin{array}{l}297,298^{*} \\
46 a, 46 b\end{array}$ & $\begin{array}{l}\text { (Mixed )a.d.f. } \\
\text { (Mixed )atmospheric }\end{array}$ & $\begin{array}{c}5 / 25-26 / 76 \\
11\end{array}$ & 23.5 & 1598 \\
\hline $\begin{array}{l}47 \\
" 1 \\
11 \\
48 \\
" 1\end{array}$ & $\begin{array}{l}299,300 \\
47 a, 47 b \\
296 \\
400 \star, 401 * \\
48 a, 48 b\end{array}$ & $\begin{array}{ll}\text { (Mixed } " \text { a.d.f. } \\
\text { (Land } \\
\text { (Mixed } \\
\text { ("tmospheric } \\
\text { a.r. } \\
\text { a.d.f. } \\
\text { atmospheric }\end{array}$ & $\begin{array}{l}5 / 26-27 / 76 \\
" 11 \\
5 / 27 / 76 \\
5 / 27-28 / 76\end{array}$ & $\begin{array}{l}22.5 \\
21.0\end{array}$ & $\begin{array}{c}1485 \\
- \\
1323\end{array}$ \\
\hline $\begin{array}{l}49 \\
11\end{array}$ & $\begin{array}{l}402,403 \\
49 a, 49 b\end{array}$ & 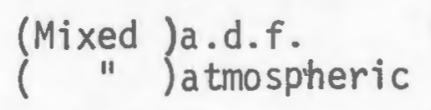 & $\underset{11}{5 / 28-29 / 76}$ & 25.0 & 1525 \\
\hline 50 & $306 *, 307 *$ & (Mixed )a.d.f. & $5 / 29-30 / 76$ & 23.0 & - \\
\hline 51 & 308,309 & (Marine)a.d.f. & $5 / 30-31 / 76$ & 25.0 & - \\
\hline 52 & $311^{*}, 312 *$ & (Mixed )a.d.f. & $5 / 31-6 / 7 / 76$ & 20.75 & - \\
\hline 53 & 313,314 & (Marine)a.d.f. & $6 / 1-2 / 76$ & 27.25 & - \\
\hline
\end{tabular}


Table 11 (Continued)

Experi- Sample Sample type ment No. No.
Date of Collection Volumet collection time(hours) of air (hours)

$\begin{array}{lllll}53 & 310 & \text { (Mixed )a.r. } & 6 / 1-2 / 76 & - \\ 54 & 315^{*}, 316^{*} & \text { (Land )a.d.f. } & 6 / 2-3 / 76 & 22.0 \\ 55 & 317,318 & \text { (Mixed )a.d.f. } & 6 / 3-5 / 76 & 46.0 \\ 56 & 319,320 & \text { (Mixed )a.d.f. } & 6 / 5-8 / 76 & 71.5 \\ 57 & 321^{*}, 322^{*} & \text { (Mixed )a.d.f. } & 6 / 8-9 / 76 & 25.0 \\ 58 & 323,324 & \text { (Mixed )a.d.f. } & 6 / 9-11 / 76 & 44.5 \\ 59 & 325,326 & \text { (Mixed )a.d.f. } & 6 / 11-13 / 76 & 52.2 \\ 60 & 327,328 & \text { (Marine)a.d.f. } & 6 / 13-15 / 76 & 44.8 \\ 61 & 329,330 & \text { (Marine)a.d.f. } & 6 / 15-17 / 76 & 48.3 \\ 62 & 333^{*}, 334^{*} & \text { (Mixed )a.d.f. } & 6 / 17-18 / 76 & 22.0 \\ 63 & 335,336 & \text { (Marine)a.d.f. } & 6 / 18-21 / 76 & 73.3 \\ 11 & 332 & \text { (Marine)a.r. } & 6 / 19-20 / 76 & - \\ 64 & 337,338 & \text { (Mixed )a.d.f. } & 6 / 21-23 / 76 & 44.7 \\ 65 & 340,341 & \text { (Land )a.d.f. } & 6 / 23-25 / 76 & 48.8 \\ 66 & 340,341 & \text { (Mixed )a.d.f. } & 6 / 25-28 / 76 & 72.0\end{array}$

*The rates of dry fallout were arrived at by subtracting values obtained from the samples below, since these samples actually represent a total of the two.

$+\quad$ Pump mean flow rate $=70 \pm 3 .\left(\mathrm{m}^{3} / \mathrm{h}\right)$

m.r. =manually collected rain

a.r. =automatically collected rain

m.d.f. =manually collected dry fallout

a.d.f.=automatically collected dry fallout 


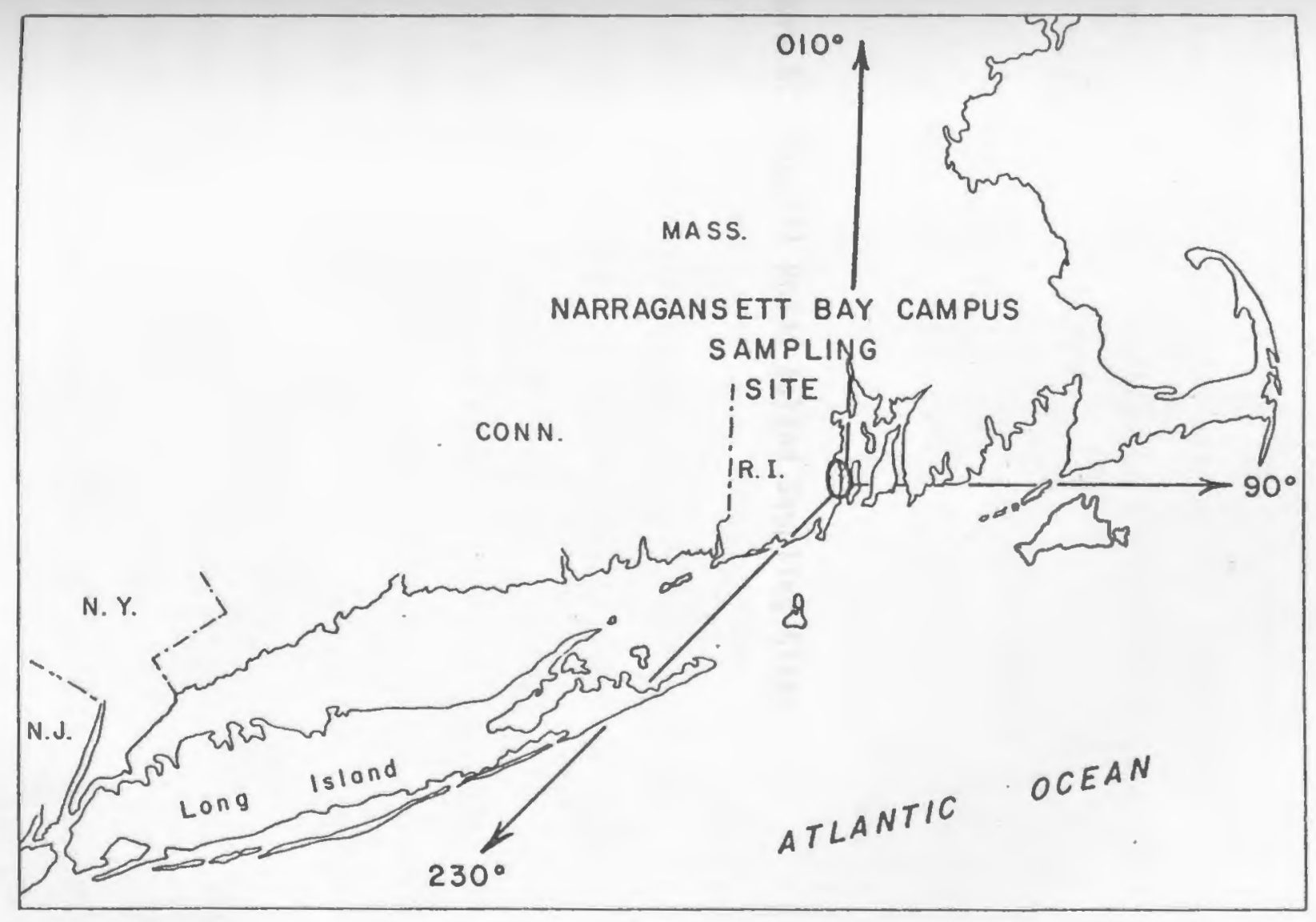

ने 
Figure 5. Coastal Rhode Island Sampling Site. 
atmospheric concentrations of particulate $\mathrm{Na}$ and $\mathrm{Mg}$ and the mean wind speed for each sample were calculated and are presented in Tables 12-14. Least-squares linear regression analysis was used, for each category of samples, to evaluate the relationship between the wind speed and both the rate of dry fallout and the atmospheric concentrations of particulate $\mathrm{Na}$ and $\mathrm{Mg}$. Intercepts, slopes and correlation coefficients calculated from these regression analyses were obtained and are also presented in Table 12-14.

\section{ii. "Corrected to Marine" samples}

Since over $50 \%$ of the total number of dry fallout and atmospheric samples were "mixed" samples, an attempt was made to recalculate the rates of dry fallout and atmospheric concentrations for the marine fraction of $\mathrm{Na}$ and $\mathrm{Mg}$ in these samples. Only "mixed" samples where the wind shifted from marine to land sectors or vice versa were chosen for this calculation. These constituted the majority of the "mixed" samples category. Calculations were made using the following parameters determined for each samples: a) the time intervais during which the local surface wind was blowing off the ocean and off land; b) the rate of dry fallout for the land fraction of the samples. This rate was assumed to be a constant, not varying with wind speed and equal to the mean rate of dry fallout calculated from the "land" subenvironment of the R.I. coastal environment. $\left(0.260 \times 10^{-12} \mathrm{gNa} / \mathrm{cm}^{2} \cdot \mathrm{sec}\right.$ and $0.215 \times 10^{-12}$ $\mathrm{gMg} / \mathrm{cm}^{2} \mathrm{sec}$ ). The $\mathrm{Na}$ and $\mathrm{Mg}$ rate of dry fallout for the marine fraction was then calculated as follows:

$$
F_{C M}=\frac{F_{M L} t_{M L}-F_{L} t_{L}}{t_{M}}
$$


Table 12. Rate of dry fallout and atmospheric concentration of $\mathrm{Na}$ and $\mathrm{Mg}$ for "marine" samples

Sample Rate of Dry Fallout $\mathrm{Mg} / \mathrm{Na} \quad$ Atmospheric \# $\quad \mathrm{Na} \quad \mathrm{Mg} \quad$ Concentration

\begin{tabular}{crrrrr} 
& & \multicolumn{3}{c}{$\mathrm{Na}\left(\mu \mathrm{g} / \mathrm{m}^{3}\right)$} & \\
\hline $\mathrm{S} 24$ & 4.60 & 0.690 & 0.13 & 0.700 & 0.120 \\
& \pm 0.481 & \pm 0.086 & & \pm 0.040 & \pm 0.006
\end{tabular}

\$27

$\begin{array}{rc}7.73 & 1.23 \\ \pm 1.31 & \pm 0.157\end{array}$

$\$ 34$

$\begin{array}{cr}1.61 & 0.380 \\ \pm 0.092 & \pm 0.021\end{array}$

\$36

$$
1.31 \quad 0.183
$$
$\pm 0.325$

$\pm 0.045$

S38

$\begin{array}{lr}2.09 & 0.460\end{array}$

\$39

$\begin{array}{rr}5.66 & 0.792\end{array}$

$\pm 7.48$

$\pm 0.043$

S51

$\begin{array}{cr}1.68 & 0.220 \\ \pm 0.121 & \pm 0.021\end{array}$

\$53

$\begin{array}{rr}3.87 & 0.580 \\ \pm 0.387 & \pm 0.059\end{array}$

$\$ 60$

$2.95 \quad 0.530$

$\pm 0.243 \quad \pm 0.074$

S61

$$
2.67 \quad 0.454
$$

$\pm 0.152 \pm 0.022$

S63

$\begin{array}{cr}5.25 & 0.787 \\ \pm 0.299 & \pm 0.042\end{array}$

Mean

3.58
\pm 2.04

$$
0.573
$$

$\pm 0.297$

0.16

2.84 $\pm 0.015$

$0.23 \quad 1.51$

0.14

0.590 $\pm 0.086$

0.22

0.310 $\pm 0.050$

$0.14 \quad 1.50$ $\pm 0.086$

0.13

0.370 $\pm 0.020$

0.205 $\pm 0.011$

$$
0.105
$$$$
\pm 0.005
$$

$\mathrm{Mg} / \mathrm{Na}$

wind

Direction Speed

(degrees) miles/hour

$\begin{array}{lll}0.17 \quad 150-180 & 13.9\end{array}$

$0.13 \quad 220-23024$.

$0.13 \quad 180-230$

8.50

0.086 $\pm 0.005$

0.173
\pm 0.009

$0.18 \quad 100-170 \quad 7.4$

$0.28 \quad 140-190 \quad 9.0$

$0.12 \quad 150-230 \quad 14.0$ $\pm 0.009$

$140-230 \quad 7.0$

0.15

0.18

0.17

0.15

$-$

0.177 $\pm 0.105$

0.17 $\pm 0.060$

$0.16 \quad 1.24$ $\pm 0.03 \pm 0.925$

Slope

$2.04 \pm$

int. $5.07 \pm$ 1.51 $14.6 \pm 2.18$

$4.05 \pm 1.39-$

$5.50 \pm 1.89$

$49.5 \pm 16.0$

$5.98 \pm 2.83$

$4.07 \pm 3.27$

Corr.

Coeff.
0.88

0.91

0.82

0.84

Form of regression equation:

wind $=$ slope $X$ (rate of dry fallout or atmospheric concentration) + intercept 
Table 13. Rate of dry fallout and atmospheric concentration of $\mathrm{Na}$ and Mg for "land" samples

\begin{tabular}{|c|c|c|c|c|c|c|c|c|}
\hline Sample & $\begin{array}{l}\text { Rate of } \mathrm{D} \\
\mathrm{Na}\end{array}$ & $\begin{array}{l}\text { bry Fallout } \\
\mathrm{Mg}\end{array}$ & $\mathrm{Mg} / \mathrm{Na}$ & & $\begin{array}{l}\text { tmospheric } \\
\text { icentration }\end{array}$ & $\mathrm{Mg} / \mathrm{Na}$ & Direction & Sd \\
\hline & $10^{-12}$ & $\mathrm{~g} \mathrm{~cm}-2 \mathrm{sec}$ & -1 & $\mathrm{Na}$ & $\left(\mu \mathrm{g} / \mathrm{m}^{3}\right)^{\mathrm{Mg}}$ & & & \\
\hline L13 & $\begin{array}{r}0.420 \\
\pm 0.024\end{array}$ & $\begin{array}{r}0.285 \\
\pm 0.015\end{array}$ & 0.68 & - & - & - & $230-270$ & 13.0 \\
\hline L17 & $\begin{array}{r}0.220 \\
\pm 0.022\end{array}$ & $\begin{array}{r}0.210 \\
\pm 0.011\end{array}$ & 0.95 & $\begin{array}{r}0.043 \\
\pm 0.008\end{array}$ & $\begin{array}{r}0.044 \\
\pm 0.002\end{array}$ & 1.0 & $300-320$ & 12.0 \\
\hline L21 & $\begin{array}{r}0.240 \\
\pm 0.027\end{array}$ & $\begin{array}{r}0.280 \\
\pm 0.016\end{array}$ & 1.2 & $\begin{array}{r}0.059 \\
\pm 0.004\end{array}$ & $\begin{array}{r}0.034 \\
\pm 0.002\end{array}$ & 0.58 & $300-360$ & 12.0 \\
\hline L22 & $\begin{array}{r}0.180 \\
\pm 0.020\end{array}$ & $\begin{array}{r}0.360 \\
\pm 0.019\end{array}$ & 2.0 & $\begin{array}{r}0.098 \\
\pm 0.005\end{array}$ & $\begin{array}{r}0.074 \\
\pm 0.004\end{array}$ & 0.76 & $260-300$ & 11.0 \\
\hline L25 & $\begin{array}{r}0.370 \\
\pm 0.037\end{array}$ & $\begin{array}{r}0.200 \\
\pm 0.016\end{array}$ & 0.54 & $\begin{array}{r}0.008 \\
\pm 0.002\end{array}$ & $\begin{array}{r}0.005 \\
\pm 0.001\end{array}$ & 0.63 & $240-320$ & 12.0 \\
\hline L29 & $\begin{array}{r}0.280 \\
\pm 0.016\end{array}$ & $\begin{array}{r}0.260 \\
\pm 0.017\end{array}$ & 0.93 & $\begin{array}{r}0.085 \\
\pm 0.005\end{array}$ & $\begin{array}{r}0.054 \\
\pm 0.003\end{array}$ & 0.64 & $270-300$ & 12.6 \\
\hline L42 & $\begin{array}{r}0.188 \\
\pm 0.019\end{array}$ & $\begin{array}{r}0.109 \\
\pm 0.015\end{array}$ & 0.58 & $\begin{array}{r}0.068 \\
\pm 0.004\end{array}$ & $\begin{array}{r}0.051 \\
\pm 0.003\end{array}$ & 0.75 & $300-310$ & 8.20 \\
\hline L43 & $\begin{array}{r}0.176 \\
\pm 0.010\end{array}$ & $\begin{array}{r}0.138 \\
\pm 0.007\end{array}$ & 0.78 & $\begin{array}{r}0.024 \\
\pm 0.001\end{array}$ & $\begin{array}{r}0.029 \\
\pm 0.001 .\end{array}$ & 1.2 & $300-310$ & 12 \\
\hline L44 ${ }^{*}$ & $\begin{array}{r}0.110 \\
\pm 0.050\end{array}$ & $\begin{array}{r}0.064 \\
\pm 0.007\end{array}$ & 0.57 & $\begin{array}{r}0.110 \\
\pm 0.006\end{array}$ & $\begin{array}{r}0.043 \\
\pm 0.002\end{array}$ & 0.39 & $280-360$ & 8.80 \\
\hline L54 & $\begin{array}{r}0.031 \\
\pm 0.003\end{array}$ & $\begin{array}{l}0.090 \\
0.009\end{array}$ & 2.9 & - & - & - & $310-360$ & 8.6 \\
\hline L65 & $\begin{array}{r}0.493 \\
\pm 0.028\end{array}$ & $\begin{array}{r}0.222 \\
\pm 0.012\end{array}$ & 0.45 & - & - & - & $230-280$ & 13.2 \\
\hline Mean & $\begin{array}{r}0.260 \\
\pm 0.129\end{array}$ & $\begin{array}{r}0.215 \\
\pm 0.012\end{array}$ & $\begin{array}{c}1.7 \\
\pm 0.73\end{array}$ & $\begin{array}{r}0.055 \\
\pm 0.030\end{array}$ & $\begin{array}{r}0.042 \\
\pm 0.020\end{array}$ & $\begin{array}{r}0.79 \\
\pm 0.21\end{array}$ & - & $\begin{array}{l}11.5 \\
\pm 1.64\end{array}$ \\
\hline $\begin{array}{l}\text { Slope } \\
\text { int. }\end{array}$ & $\begin{array}{l}9.57 \\
8.98\end{array}$ & $\begin{array}{l}12.1 \\
8.85\end{array}$ & - & $\begin{array}{r}-11.9 \\
12.1\end{array}$ & $\begin{array}{l}21.3 \\
12.3\end{array}$ & - & - & \\
\hline $\begin{array}{l}\text { Corr. } \\
\text { Coeff. }\end{array}$ & 0.75 & 0.60 & - & -0.26 & -0.31 & - & - & \\
\hline
\end{tabular}

*Not included in calculation of mean, slope, int and corr. coeff.

Form of regression equation:

wind $=$ slope $x$ (rate of dry fallout or atmospheric concentration/ + intercept 
Table 14. Rate of dry fallout and atmospheric concentration of $\mathrm{Na}$ and Mg for "mixed" samples

\begin{tabular}{|c|c|c|c|c|c|c|c|c|}
\hline \multirow{2}{*}{$\begin{array}{l}\text { Sample } \\
\text { S/L } 5\end{array}$} & \multicolumn{2}{|c|}{$\begin{array}{l}\text { Rate of Dry Fallou } \\
\mathrm{Na} \\
10^{-12} \mathrm{~g} \mathrm{~cm}^{-2} \mathrm{se}\end{array}$} & $\begin{array}{l}\mathrm{Mg} / \mathrm{Na} \\
-1\end{array}$ & \multicolumn{2}{|c|}{$\begin{array}{c}\text { Atmospheric } \\
\text { Concentration } \\
\mathrm{Na}\left(\mu \mathrm{g} / \mathrm{m}^{3}\right) \mathrm{Mg}\end{array}$} & $\mathrm{Mg} / \mathrm{Na}$ & \multicolumn{2}{|c|}{$\begin{array}{l}\text { Wind } \\
\text { Direction Speed } \\
\text { (degrees) miles/hour }\end{array}$} \\
\hline & $\begin{array}{r}0.801 \\
\pm 0.060\end{array}$ & $\begin{array}{r}0.072 \\
\pm 0.012\end{array}$ & 0.09 & - & - & - & $\begin{array}{l}260-360+ \\
160-180\end{array}$ & 4.0 \\
\hline S/L10 & $\begin{array}{c}1.11 \\
\pm 0.105\end{array}$ & $\begin{array}{r}0.246 \\
\pm 0.031\end{array}$ & 0.22 & - & - & - & $200-300$ & 12.0 \\
\hline$S / L 14^{a}$ & $\begin{array}{r}0.780 \\
\pm 0.044\end{array}$ & $\begin{array}{r}0.550 \\
\pm 0.062\end{array}$ & 0.70 & $\begin{array}{r}0.450 \\
\pm 0.026\end{array}$ & $\begin{array}{l}0.105 \\
0.007\end{array}$ & 0.24 & $\begin{array}{c}230-300 \\
30-60\end{array}$ & 13.7 \\
\hline S/L15 & $\begin{array}{c}2.20 \\
\pm 0.161\end{array}$ & $\begin{array}{l}0.320 \\
0.016\end{array}$ & 0.15 & $\begin{array}{c}1.24 \\
\pm 0.071\end{array}$ & $\begin{array}{r}0.160 \\
\pm 0.009\end{array}$ & 0.13 & $\begin{array}{c}69-90 \\
180-220\end{array}$ & 123 \\
\hline S/L26 & $\begin{array}{c}1.65 \\
\pm 0.094\end{array}$ & $\begin{array}{r}0.590 \\
\pm 0.032\end{array}$ & 0.35 & $\begin{array}{r}0.615 \\
\pm 0.035\end{array}$ & $\begin{array}{r}0.130 \\
\pm 0.007\end{array}$ & 0.21 & $\begin{array}{l}240-290 \\
220-230\end{array}$ & 14.8 \\
\hline S/L30 & $\begin{array}{r}0.540 \\
\pm 0.036\end{array}$ & $\begin{array}{r}0.330 \\
\pm 0.028\end{array}$ & 0.60 & $\begin{array}{r}0.640 \\
\pm 0.036\end{array}$ & $\begin{array}{r}0.145 \\
\pm 0.008\end{array}$ & 0.23 & $\begin{array}{l}250-270 \\
160-190\end{array}$ & 12.8 \\
\hline S/L31 & $\begin{array}{c}2.04 \\
\pm 0.172\end{array}$ & $\begin{array}{r}0.430 \\
\pm 0.039\end{array}$ & 0.20 & $\begin{array}{c}2.16 \\
\pm 0.123\end{array}$ & $\begin{array}{r}0.4 ? .8 \\
\pm 0.088\end{array}$ & 0.20 & $\begin{array}{c}230 \\
160-200\end{array}$ & 15.7 \\
\hline S/L33 & $\begin{array}{r}0.650 \\
\pm 0.076\end{array}$ & $\begin{array}{r}0.340 \\
\pm 0.018\end{array}$ & 0.52 & $\begin{array}{r}0.235 \\
\pm 0.013\end{array}$ & $\begin{array}{r}0.080 \\
\pm 0.004\end{array}$ & 0.34 & $280-310$ & 7.3 \\
\hline S/L35 & $\begin{array}{c}1.20 \\
\pm 0.068\end{array}$ & $\begin{array}{r}0.330 \\
\pm 0.018\end{array}$ & 0.27 & $\begin{array}{r}0.760 \\
\pm 0.043\end{array}$ & $\begin{array}{r}0.120 \\
\pm 0.006\end{array}$ & 0.16 & $220-240$ & 15.5 \\
\hline$S / L 40$ & $\begin{array}{c}2.53 \\
\pm 0.370\end{array}$ & $\begin{array}{r}0.455 \\
\pm 0.072\end{array}$ & 0.18 & $\begin{array}{r}0.557 \\
\pm 0.032\end{array}$ & $\begin{array}{r}0.108 \\
\pm 0.006\end{array}$ & 0.19 & $\begin{array}{l}220-250 \\
280-300\end{array}$ & 17.7 \\
\hline S/L4I & $\begin{array}{r}0.943 \\
\pm 0.125\end{array}$ & $\begin{array}{r}0.330 \\
\pm 0.018\end{array}$ & 0.35 & $\begin{array}{c}1.06 \\
\pm 0.060\end{array}$ & $\begin{array}{r}0.175 \\
\pm 0.009\end{array}$ & 0.17 & $\begin{array}{l}250-300 \\
300-50\end{array}$ & 7.0 \\
\hline$\$ / L 45^{a}$ & $\begin{array}{c}1.83 \\
\pm 0.131\end{array}$ & $\begin{array}{r}0.329 \\
\pm 0.045\end{array}$ & 0.18 & $\begin{array}{r}0.723 \\
\pm 0.041\end{array}$ & $\begin{array}{r}0.133 \\
\pm 0.007\end{array}$ & 0.18 & $30-70$ & 20.6 \\
\hline$S / L 46^{a}$ & $\begin{array}{l}1.14 \\
\pm 0.383\end{array}$ & $\begin{array}{r}0.227 \\
\pm 0.047\end{array}$ & 0.20 & $\begin{array}{c}1.28 \\
\pm 0.073\end{array}$ & $\begin{array}{r}0.195 \\
\pm 0.011\end{array}$ & 0.15 & $360-60$ & 10.9 \\
\hline S/L47 & $\begin{array}{r}0.659 \\
\pm 0.250\end{array}$ & $\begin{array}{r}0.152 \\
\pm 0.008\end{array}$ & 0.23 & $\begin{array}{r}0.606 \\
\pm 0.035\end{array}$ & $\begin{array}{r}0.116 \\
\pm 0.006\end{array}$ & 0.19 & $\begin{array}{l}220-230 \\
270-340\end{array}$ & 8.3 \\
\hline S/L48 & $\begin{array}{r}0.219 \\
\pm 0.075\end{array}$ & $\begin{array}{r}0.624 \\
\pm 0.057\end{array}$ & $2.9^{\mathrm{a}}$ & $\begin{array}{r}0.280 \\
\pm 0.016\end{array}$ & $\begin{array}{r}0.109 \\
\pm 0.006\end{array}$ & 0.39 & $\begin{array}{l}250-360 \\
160-260\end{array}$ & 7.3 \\
\hline S/L49 & \pm 0.636 & $\begin{array}{r}0.146 \\
\pm 0.008\end{array}$ & 0.23 & $\begin{array}{r}0.393 \\
\pm 0.022\end{array}$ & $\begin{array}{r}0.109 \\
\pm 0.006\end{array}$ & 0.27 & $\begin{array}{l}230-260 \\
160-230\end{array}$ & 8.4 \\
\hline$S / L 50$ & $\begin{array}{c}1.57 \\
\pm 0.089\end{array}$ & $\begin{array}{r}0.315 \\
\pm 0.017\end{array}$ & 0.20 & - & - & - & $\begin{array}{l}120-160 \\
360-80\end{array}$ & 4.8 \\
\hline S/L52 & $\begin{array}{r}0.886 \\
\pm 0.090\end{array}$ & $\begin{array}{r}0.195 \\
\pm 0.020\end{array}$ & 0.22 & - & - & - & $\begin{array}{l}180-240 \\
290-80\end{array}$ & 7.0 \\
\hline
\end{tabular}


Table 14. (Continued)

\begin{tabular}{|c|c|c|c|c|c|c|c|c|}
\hline S/L55 & $\begin{array}{r}0.349 \\
\pm 0.091\end{array}$ & $\begin{array}{r}0.122 \\
\pm 0.018\end{array}$ & 0.35 & - & - & - & $120-360$ & 8.3 \\
\hline \$/L56 & $\begin{array}{r}0.624 \\
\pm 0.062\end{array}$ & $\begin{array}{r}0.256 \\
\pm 0.016\end{array}$ & 0.41 & - & - & - & $180-300$ & 16.6 \\
\hline S/L57 & $\begin{array}{r}0.586 \\
\pm 0.060\end{array}$ & $\begin{array}{r}0.234 \\
\pm 0.030\end{array}$ & 0.40 & - & - & - & $\begin{array}{l}230-240 \\
230-270\end{array}$ & 7.7 \\
\hline S/L58 & $\begin{aligned} & 1.20 \\
& \pm 0.068\end{aligned}$ & $\begin{array}{r}0.540 \\
\pm 0.048\end{array}$ & 0.45 & - & - & - & $\begin{array}{l}160-220 \\
230-250\end{array}$ & 5.9 \\
\hline S/L59 & $\begin{array}{r}0.849 \\
\pm 0.048\end{array}$ & $\begin{array}{r}0.297 \\
\pm 0.040\end{array}$ & 0.35 & - & - & - & $\begin{array}{l}230-360 \\
200-230\end{array}$ & 14.0 \\
\hline S/L62 & $\begin{aligned} & 1.85 \\
& \pm 0.020\end{aligned}$ & $\begin{array}{r}0.462 \\
\pm 0.050\end{array}$ & 0.25 & - & - & - & $\begin{array}{l}160-240 \\
230-29\end{array}$ & 9.9 \\
\hline S/L64 & $\begin{array}{c}1.74 \\
\pm 0.170\end{array}$ & $\begin{array}{r}0.261 \\
\pm 0.014\end{array}$ & 0.15 & - & - & - & $180-240$ & 11.1 \\
\hline S/L66 & $\begin{array}{r}0.347 \\
\pm 0.020\end{array}$ & $\begin{array}{r}0.108 \\
\pm 0.006\end{array}$ & 0.31 & - & - & - & $\begin{array}{l}270-300 \\
170-230\end{array}$ & 8.6 \\
\hline Mean & $\begin{array}{c}1.11 \\
\pm 0.627\end{array}$ & $\begin{array}{r}0.318 \\
\pm 0.151\end{array}$ & $\begin{array}{r}0.30 \\
\pm 0.15\end{array}$ & $\begin{array}{r}0.786 \\
\pm 0.510\end{array}$ & $\begin{array}{r}0.151 \\
\pm 0.085\end{array}$ & $\begin{array}{r}0.22 \\
\pm 0.07\end{array}$ & - & $\begin{array}{l}10.6 \\
\pm 4.10\end{array}$ \\
\hline $\begin{array}{l}\text { STope } \\
\text { int. }\end{array}$ & $\begin{array}{l}3.50 \\
6.77\end{array}$ & $\begin{array}{l}8.82 \\
7.87\end{array}$ & - & $\begin{array}{l}2.15 \\
10.6\end{array}$ & $\begin{array}{l}10.8 \\
10.7\end{array}$ & - & & \\
\hline Corr. & 0.53 & 0.32 & & 0.26 & 0.21 & - & & \\
\hline
\end{tabular}

Coeff.

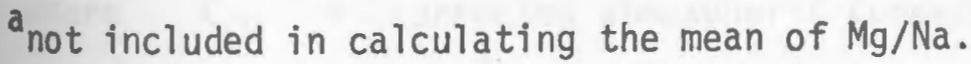

Form of regression equation:

wind $=$ slope $X$ (rate of dry fallout or atmospheric concentration) + intercept 
where $F_{C M}=$ corrected rate of dry fallout in $\mathrm{g} \times 10^{-12} \mathrm{~cm}^{-2} \mathrm{sec}^{-1}$ for $\mathrm{Na}$ or $\mathrm{Mg}$.

$F_{M L}=$ rate of dry fallout for a "mixed" sample in $g \times 10^{-12}$ $\mathrm{cm}^{-2} \mathrm{sec}^{-1}$ for $\mathrm{Na}$ or $\mathrm{Mg}$.

$F_{L}=$ assumed rate of dry fallout for "land" fraction $=0.260 \times 10^{-12} \mathrm{gNa} / \mathrm{cm}^{2} / \mathrm{sec}$ $=0.215 \times 10^{-12} \mathrm{gMg} / \mathrm{cm}^{2} / \mathrm{sec}$

$t_{M L}=$ total sampling period in seconds for a "mixed" sample.

$t_{L}=$ time in seconds where wind was blowing off the land.

$t_{M}=$ time in seconds where wind was blowing off the ocean.

Using a similar approach the atmospheric concentrations of particulate $\mathrm{Na}$ and $\mathrm{Mg}$ for the marne fraction of "mixed" atmospheric samples were calculated as follows:

$$
c_{C M}=\frac{c_{M L} t_{M L}-c_{L} t_{L}}{t_{M}}
$$

where $C_{C M}=$ corrected atmospheric concentration of $\mathrm{Na}$ or $\mathrm{Mg}$ in $\mathrm{Mg} / \mathrm{m}^{3}$.

$C_{M L}=$ concentrations of atmospheric particulate $\mathrm{Na}$ or $\mathrm{Mg}$ in $u g / m^{3}$ for a "mixed" sample.

$C_{L}=$ assumed concentration of $\mathrm{Na}$ or $\mathrm{Mg}$ in $\mathrm{ug} / \mathrm{m}^{3}$ for the land fraction of the sample $=0.055 \mathrm{ugNa} / \mathrm{m}^{3}$;

$0.042 \mathrm{ugMg} / \mathrm{m}^{3}$ (mean concentrations of particulate $\mathrm{Na}$ and $\mathrm{Mg}$ calculated from land subenvironments of R.I. coastal environment (Table 12).

$t_{M L}, t_{L}, t_{M}=$ as described previously. 
The "corrected-to-marine" rates of dry fallout, and atmospheric concentrations for particulate $\mathrm{Na}$ and $\mathrm{Mg}$, the corrected $\mathrm{Mg} / \mathrm{Na}$ ratios, and the wind speeds during sampling of the marine fractions of the "mixed" samples are given in Table 15. Correlation between these values and wind speed as well as slopes and intercepts from linear least square regression analys is are also tabulated in Table 15. These same parameters were recalculated for the total sample population after the "marine" samples were combined with the "corrected to marine" samples (Table 16).

Since "mixed" samples collected within the wind sector 010-090" showed a different trend from the rest of "mixed" samples, they were listed separately in Table 17. Since sample 14 has a continental fraction, it was corrected to the $010-090^{\circ}$ sector.

b. Samples collected aboard RV/Trident

Dry fallout samples were collected during cruise \#169 from Narragansett to Bermuda to Narragansett in June-July 1975. The rates of $\mathrm{Na}$ and $\mathrm{Mg}$ dry fallout were calculated for the samples and are reported along with surface wind speed, in Table 18. Fig. 6 shows the stations where these samples were collected.

C. Deposition velocity for particulate $\mathrm{Na}$ and $\mathrm{Mg}$

The deposition velocity was defined earlier in Chapter I. $\mathrm{Na}$ and $\mathrm{Mg}$ deposition velocities in $\mathrm{cm} / \mathrm{sec} \quad$ calculated for samples collected in the three sampling categories ("marine", "land", and "mixed") and for the"corrected to marine" samples are given in Table 19. The mean $\mathrm{Na}$ and $\mathrm{Mg}$ deposition velocities for each subenvironment and the overall mean for the R.I. coastal environment are also presented in Table 19. 
Table 15. Corrected-to-Marine rate of dry fallout and atmospheric concentrations of $\mathrm{Na}$ and $\mathrm{Mg}$ for "mixed" samples

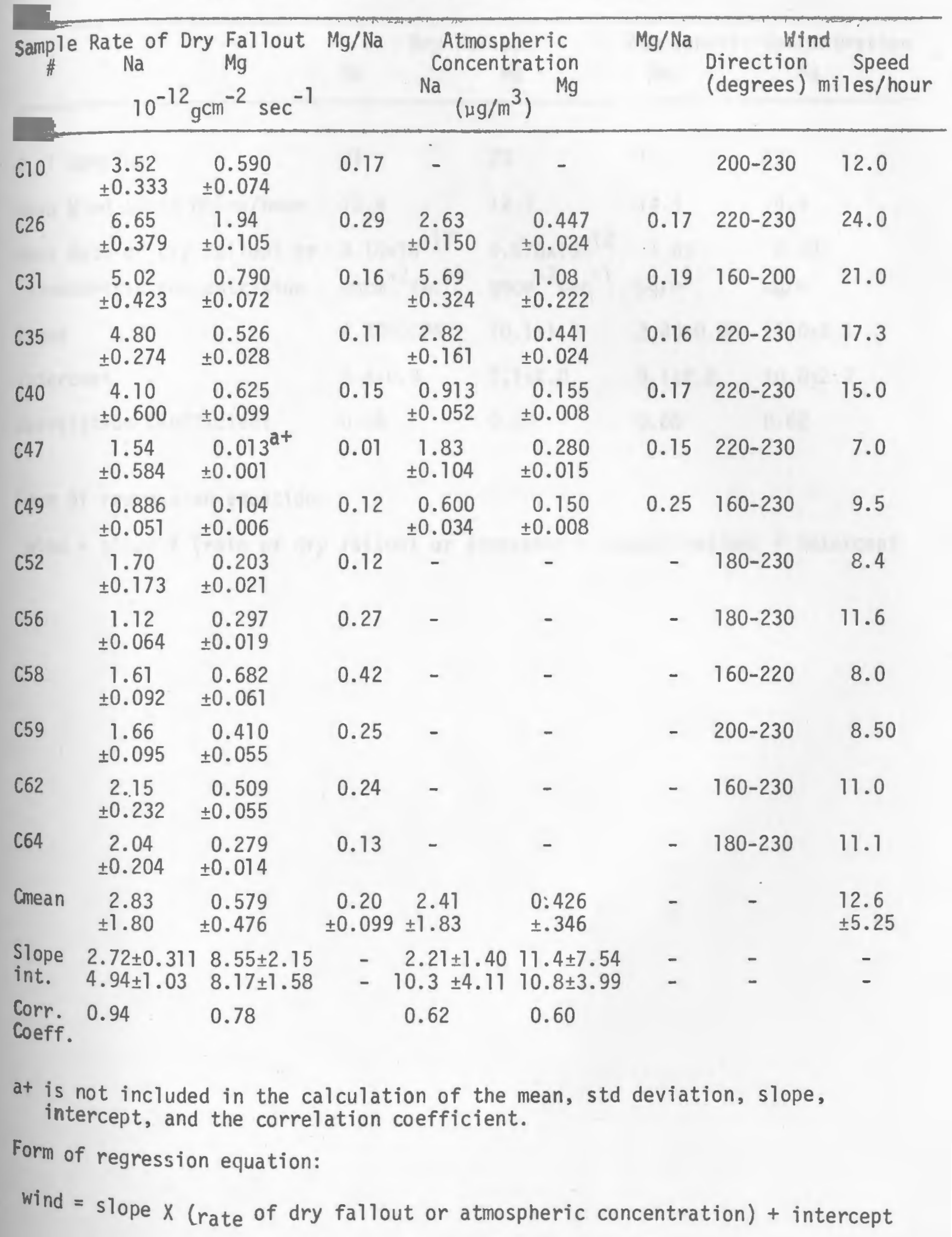


Table 16. "Marine" samples and "Corrected-to-marine" samples Correlation with wind speed

Dry Fallout

$\mathrm{Na}$

$\mathrm{Mg}$

Atmospheric Concentration

$\mathrm{Na}$

$\mathrm{Mg}$

\# of samples $\quad 24 \quad 23 \quad 12 \quad 12$

Mean Wind Speed miles/hour 12.6

12.7

14.4

14.4

Mean Rate of dry fallout or

$3.18 \times 10^{-12}$

$0.576 \times 10^{-12}$

1.83

0.301

Atmospheric concentration $\mathrm{gmcm}^{-2} \mathrm{sec}^{-1}$

$\mathrm{gmcm}^{-2} \sec ^{-1}$

$\mu \mathrm{g} / \mathrm{m}^{3}$

$\mu \mathrm{g} / \mathrm{m}^{3}$

Slope

$2.20 \pm 0.24$

$10.1 \pm 1.5$

$2.80 \pm 0.96$

$14.0 \pm 5.6$

intercept

$5.4 \pm 0.9$

$7.7 \pm 7.0$

$9.1 \pm 2.2$

$10.0 \pm 2.3$

Correlation Coefficient

0.88

0.80

0.68

0.62

Form of regression equation:

wind $=$ slope $X$ (rate of dry fallout or atmospheric concentration) + intercept 
Table 17. Rate of dry fallout and atmospheric concentrations of $\mathrm{Na}$ and $\mathrm{Mg}$. Wind direction $010^{\circ}-090^{\circ}$

Rate of dry fallout $\mathrm{Mg} / \mathrm{Na}$ Atmospheric $\mathrm{Mg} / \mathrm{Na}$

Sample No.

$$
10^{-12} \mathrm{gm} / \mathrm{cm}^{2} / \mathrm{sec}
$$

Wind

Speed miles/hour

$\begin{array}{lrllllll}14 & 1.30 & 0.885 & 0.68^{\mathrm{a}} & 0.845 & 0.168 & 0.20 & 13.7 \\ 45 & 1.83 & 0.329 & 0.18 & 0.723 & 0.133 & 0.18 & 20.6 \\ 46 & 1.14 & 0.227 & 0.20 & 1.28 & 0.195 & 0.15 & 10.9 \\ 50 & 1.57 & 0.315 & 0.20 & - & - & - & 4.8 \\ \text { mean } & 1.46 & 0.439 & 0.19 & 0.946 & 0.165 & 0.18 & 12.5\end{array}$

${ }^{a}$ Not included in calculating the mean because there is a possible error while adjusting the rate to the $010-090^{\circ}$ sector. 
Table 18. Atmospheric flux of $\mathrm{Na}$ and $\mathrm{Mg}$ to the North Atlantic Ocean (R/V Trident samples)

\begin{tabular}{|c|c|c|c|c|c|c|c|}
\hline $\begin{array}{l}\text { Station } \\
\text { No. }\end{array}$ & Samples & Date & $\begin{array}{l}\text { Location } \\
\text { (g }\end{array}$ & $\begin{array}{l}\mathrm{Na}^{\mathrm{C}} \\
\mathrm{g} \times 10^{-12} \mathrm{Cl}\end{array}$ & $\left.2^{\mathrm{Mg}^{\mathrm{c}}} \mathrm{sec}^{-1}\right)$ & $\mathrm{Mg} / \mathrm{Na}$ & $\begin{array}{l}\text { Wind Speed } \\
\text { miles/hour }\end{array}$ \\
\hline & \multicolumn{7}{|c|}{$7 \pi$} \\
\hline 1 & TRT-TR2 & $6 / 24-25 / 75$ & $\begin{array}{l}37.46 \mathrm{~N}-69.24 \mathrm{~W} \\
35.27 .7 \mathrm{~N}-67.3 \mathrm{~W}\end{array}$ & 53.6 & 6.81 & 0.13 & 27.0 \\
\hline 2 & TR3-TR4 & $6 / 25-27 / 75$ & $\begin{array}{l}35.2 \mathrm{~N}-67.2 \mathrm{~W} \\
31.54 \mathrm{~N}-64.51 \mathrm{~W}\end{array}$ & 5.65 & 0.632 & 0.11 & 16.0 \\
\hline 3 & TR5-TR6 & $6 / 27-29 / 75$ & $\begin{array}{l}32.03 .6-67.2 \mathrm{~W} \\
32.10 .6 \mathrm{~N}-64.4 \mathrm{~W}\end{array}$ & 3.80 & 0.513 & 0.14 & 12.0 \\
\hline 4 & TR10 & $7 / 3-6 / 75$ & $\begin{array}{l}28.38 \mathrm{~N}-64.3 \mathrm{~W} \\
29.42 \mathrm{~N}-64.55 \mathrm{~W}\end{array}$ & $3.40^{\star}$ & 0.408 & $0.12^{*}$ & 13.0 \\
\hline 5 & TR11 & $7 / 6-8 / 75$ & $\begin{array}{l}30.18: 9 \mathrm{~N}-65.32 \mathrm{~W} \\
33.46 \mathrm{~N}-66.56 \mathrm{~W}\end{array}$ & $35.4^{*}$ & 4.25 & $0.12^{*}$ & $10+25^{b}$ \\
\hline 6 & $\operatorname{TR} 13^{\mathrm{a}}$ & $7 / 10-11 / 75$ & $\begin{array}{l}38.39 \mathrm{~N}-69.40 \mathrm{~W} \\
41.19 \mathrm{~N}-71.18 \mathrm{~W}\end{array}$ & $52.6^{*}$ & 6.31 & $0.12^{*}$ & 22.0 \\
\hline 7 & TR14 & $7 / 10-11 / 75$ & $"$ & $57.6^{*}$ & 6.20 & $0.12^{*}$ & 22.0 \\
\hline
\end{tabular}

a $-0.025 \mathrm{~cm}$ rain shower collected. Sample represents a total fallout. b-Within the last 24 hour of experiment the mean wind speed reached $25 \mathrm{~m} / \mathrm{h}$. *-Na calculated from the $\mathrm{Mg}$ data using the $0.12 \mathrm{Mg} / \mathrm{Na}$ ratio c-Precision is $\pm 20 \%$. 
Table 19. Deposition velocities for atmospheric $\mathrm{Na}$ and $\mathrm{Mg}$

Sample $\begin{array}{ccl}\mathrm{V}_{\mathrm{g}}, \mathrm{Na} & \mathrm{V}_{\mathrm{g}}, \mathrm{Mg} & \text { Wind Speed } \\ \mathrm{cmsec}^{-1} & \mathrm{cmsec}^{-1} & \begin{array}{l}\text { miles/hour } \\ \text { miles }\end{array}\end{array}$

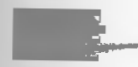

\begin{tabular}{|c|c|c|c|c|c|c|c|}
\hline $\mathrm{LI7}$ & 5.1 & 4.8 & 12.0 & $S / L \quad 30$ & 0.84 & 2.3 & 12.8 \\
\hline L21 & 4.1 & 8.2 & 12.0 & $S / L 31$ & 0.94 & 1.0 & 15.7 \\
\hline L.22 & 1.8 & 4.9 & 11.0 & $S / L 33$ & 2.8 & 4.2 & 7.3 \\
\hline L25 & - & - & 12.0 & $S / L 35$ & 1.6 & 2.8 & 15.5 \\
\hline L29 & 3.3 & 4.8 & 12.6 & $S / L 40$ & 4.5 & 4.2 & 17.7 \\
\hline L42 & 2.8 & 2.1 & 8.2 & S/L 41 & 0.89 & 1.9 & 7.0 \\
\hline L43 & 7.3 & 4.8 & 12.0 & S/L 45 & 2.5 & 2.5 & 20.6 \\
\hline L44 & 1.0 & 1.5 & 8.8 & S/L 46 & 0.89 & 1.2 & 10.9 \\
\hline \multirow{3}{*}{ Mean $_{L}$} & 3.6 & 4.4 & - & S/L 47 & 1.1 & 1.3 & 8.3 \\
\hline & \pm 2.1 & \pm 2.1 & & $S / L 48$ & 0.78 & - & 7.3 \\
\hline & & & & $S / L 49$ & 1.6 & 1.3 & 8.4 \\
\hline S24 & 6.6 & 5.8 & 13.9 & \multirow{2}{*}{${ }^{\text {Mean }_{S / L}}$} & 1.8 & 2.6 & - \\
\hline \$27 & 2.7 & 3.3 & 26.0 & & \pm 7.1 & \pm 7.4 & \\
\hline \$34 & 1.1 & 1.9 & 8.5 & C 26 & 2.5 & 4.3 & 14.8 \\
\hline S36 & 2.2 & 1.7 & 7.4 & C 31 & 0.88 & 0.73 & 15.7 \\
\hline S38 & 6.7 & 5.3 & 9.0 & C 35 & 1.7 & 1.2 & 15.5 \\
\hline$\$ 39$ & 3.8 & 4.6 & 14.0 & C 40 & 4.5 & 4.0 & 15.0 \\
\hline \multirow[t]{2}{*}{ Hean $_{S}$} & 3.9 & 3.8 & \multirow[t]{2}{*}{-} & C 47 & 0.84 & - & 7.0 \\
\hline & \pm 2.3 & \pm 1.7 & & C 49 & 1.5 & 0.69 & 9.5 \\
\hline S/L14 & 1.7 & 5.2 & 13.7 & Mean $_{C}$ & 2.0 & 2.2 & - \\
\hline \multirow[t]{3}{*}{ S/LI5 } & 1.8 & 2.0 & 12.3 & & \pm 7.4 & \pm 1.8 & \\
\hline & & & & Mean & 2.4 & 3.0 & - \\
\hline & & & & $L+S+S / L+C$ & \pm 1.6 & \pm 1.6 & \\
\hline
\end{tabular}

\section{where:}

$L \quad=$ "land" samples

$S=$ "marine" samples

$S / L=$ "mixed" samples

C = "corrected-to-marine" samples 
Figure 6. R/V Trident Cruise \#169, sampling stations. 


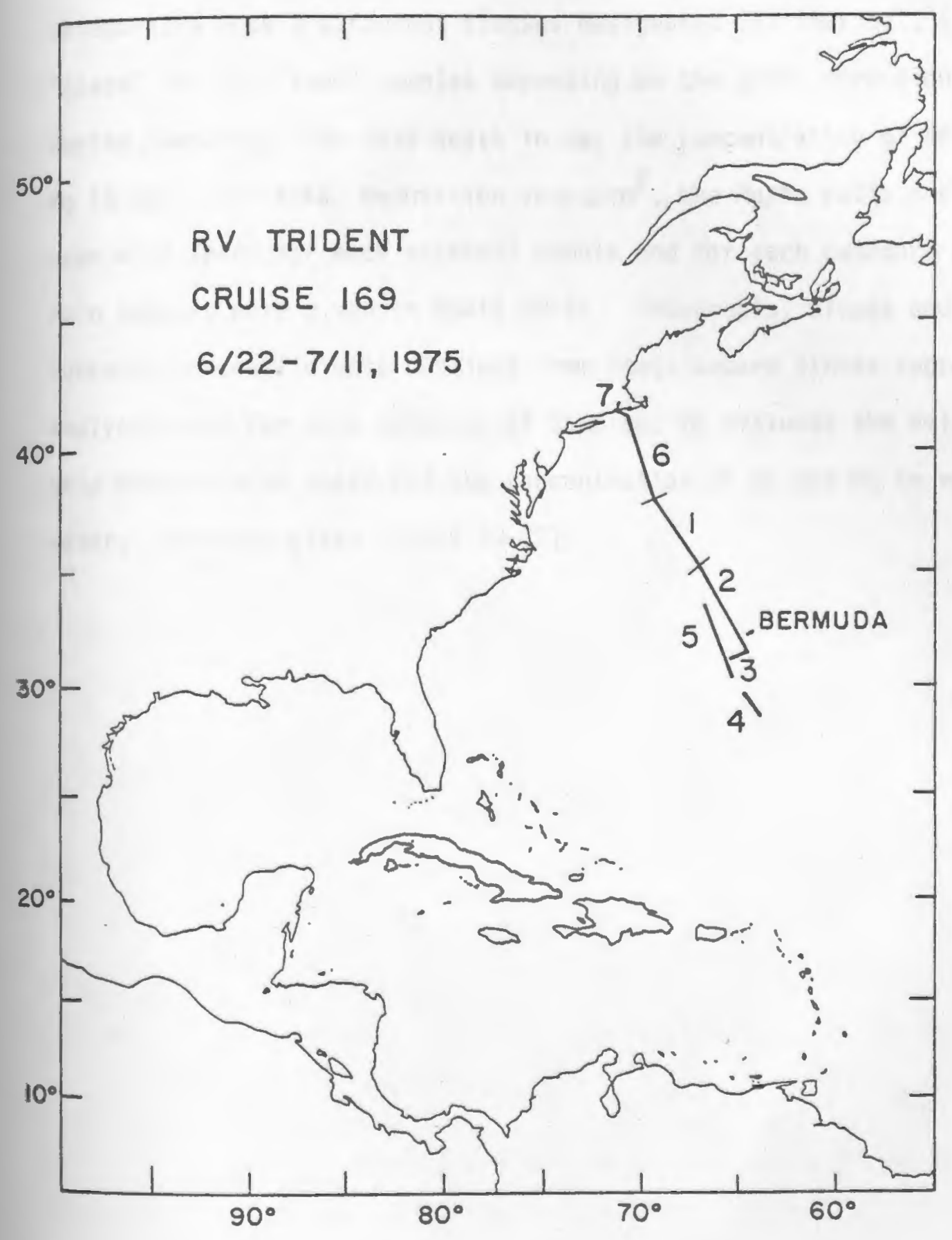




\section{Rainfall Samples}

Similar to dry fallout and atmospheric samples, rainfall data were categorized into 3 different classes designated (S) "marine", (S/L) "mixed" and (L) "land" samples depending on the wind direction during sampling. The rain depth in $\mathrm{cm}$, the concentration of $\mathrm{Na}$ and Mg in $\mathrm{mg} / \mathrm{l}$, the total deposition in $\mu \mathrm{g} / \mathrm{cm}^{2}$, the $\mathrm{Mg} / \mathrm{Na}$ ratio and the mean wind speed for each rainfall sample and for each category of rain samples were given in Table 20-22. Intercepts, slopes and correlation coefficients obtained from least square linear regression analysis used for each category of samples, to evaluate the relationship between wind speed and the concentration of $\mathrm{Na}$ and $\mathrm{Mg}$ in rain water, are also given (Table 20-22). 
Table 20. Na and $\mathrm{Mg}$ in "marine" rain samples

Sample Date Sample $h \quad \mathrm{Na}$ Type $\mathrm{cm}$
$\mathrm{Mg}$

$\mathrm{mg} / 1$
$\mathrm{Na} \mathrm{Mg} \mathrm{Mg} / \mathrm{W}$ Winđđ Total deposition/ Na Miles/hour $\mu \mathrm{g} / \mathrm{cm}^{2}$. rain

\begin{tabular}{|c|c|c|c|c|c|c|c|c|c|}
\hline 53 & $\begin{array}{c}12 / 15 / \\
75\end{array}$ & TM & 0.25 & $\begin{array}{c}3.28 \\
\pm 0.328\end{array}$ & $\begin{array}{r}0.370 \\
\pm 0.037\end{array}$ & $\begin{array}{r}0.819 \\
\pm 0.082\end{array}$ & $\begin{array}{c}0.098 \\
\pm 0.01\end{array}$ & 0.12 & 7.60 \\
\hline 56 & $\begin{array}{l}12 / 30- \\
31 / 75\end{array}$ & $T M$ & 1.4 & $\begin{array}{r}0.613 \\
\pm 0.086\end{array}$ & $\begin{array}{r}0.074 \\
\pm 0.023\end{array}$ & $\begin{array}{c}1.02 \\
\pm 0.109\end{array}$ & $\begin{array}{r}0.125 \\
\pm 0.013\end{array}$ & 0.12 & 5.5 \\
\hline$\$ 23$ & $\begin{array}{c}5 / 12 \\
76\end{array}$ & $T M$ & 2.7 & $\begin{array}{c}2.82 \\
\pm 0.460\end{array}$ & $\begin{array}{r}0.379 \\
\pm 0.039\end{array}$ & $\begin{array}{c}6.02 \\
\pm 0.982\end{array}$ & $\begin{array}{r}0.809 \\
\pm 0.089\end{array}$ & & \\
\hline 528 & $5 / 7 /$ & TM & 0.45 & $\begin{array}{c}1.75 \\
\pm 0.050\end{array}$ & $\begin{array}{c}0.300 \\
\pm 0.00\end{array}$ & $\begin{array}{r}0.795 \\
\pm 0.033\end{array}$ & $\begin{aligned} & 0.136 \\
\pm & 0.00\end{aligned}$ & 0.17 & 11.7 \\
\hline 32 & $\begin{array}{c}5 / 11 / 12 / \\
76\end{array}$ & TM & 0.87 & $\begin{array}{r}0.920 \\
\pm 0.092\end{array}$ & $\begin{array}{r}0.133 \\
\pm 0.010\end{array}$ & $\begin{array}{r}0.801 \\
\pm 0.080\end{array}$ & $\begin{array}{r}0.116 \\
\pm 0.009\end{array}$ & 0.14 & 10.5 \\
\hline S37 & $\begin{array}{c}5 / 17 / \\
76\end{array}$ & RA & 1.8 & $\begin{array}{r}0.600 \\
\pm 0.060\end{array}$ & $\begin{array}{r}0.100 \\
\pm 0.010\end{array}$ & $\begin{array}{c}1.05 \\
\pm 0.105\end{array}$ & $\begin{array}{r}0.179 \\
\pm 0.018\end{array}$ & 0.17 & 9.1 \\
\hline$\$ 39$ & $\begin{array}{c}5 / 19 / \\
76\end{array}$ & RA & 0.35 & $\begin{array}{c}1.50 \\
\pm 0.500\end{array}$ & $\begin{array}{r}0.250 \\
\pm 0.025\end{array}$ & $\begin{array}{r}0.493 \\
\pm 0.175\end{array}$ & $\begin{array}{r}0.082 \\
\pm 0.009\end{array}$ & 0.17 & 9.00 \\
\hline S63 & $\begin{array}{c}6 / 19 / 20 / \\
76\end{array}$ & $R A^{*}$ & 0.43 & $\begin{aligned} & 3.00 \\
\pm & 0.300\end{aligned}$ & $\begin{array}{r}0.410 \\
\pm 0.041\end{array}$ & $\begin{array}{r}0.974 \\
\pm 0.097\end{array}$ & $\begin{array}{r}0.133 \\
\pm 0.013\end{array}$ & 0.14 & 11.9 \\
\hline Mean & - & - & $\begin{array}{c}1.1 \\
\pm 0.88\end{array}$ & $\begin{array}{r}1.62 \\
\pm 0.77\end{array}$ & $\begin{array}{r}0.238 \\
\pm 0.140\end{array}$ & $\begin{array}{r}1.70 \\
\pm 2.07\end{array}$ & $\begin{array}{r}0.248 \\
\pm 0.294\end{array}$ & $\begin{array}{c}0.15 \\
\pm 0.018\end{array}$ & $\begin{array}{r}10.0 \pm \\
2.42\end{array}$ \\
\hline $\begin{array}{l}\text { Slope } \\
\text { Int. }\end{array}$ & - & - & - & $\begin{array}{l}1.87 \pm 0.70 \\
7.04 \pm 7.29\end{array}$ & $\begin{array}{c}14.3 \pm 4.7 \\
6.66 \pm 1.2\end{array}$ & $26-$ & - & - & - \\
\hline & - & - & - & 0.77 & 0.81 & 0.46 & 0.48 & - & - \\
\hline
\end{tabular}

Coeff.

$T=$ Total fallout, $R=$ Rainfall

$M=$ Manually collected sample; $A=$ samples collected using the automatic rain dry fallout collector

* Thunderstorm

Sample 53 was not included in the calculation of the mean and regression analys is.

Form of regression equation:

wind $=$ (slope $x$ rain concentration $)+$ intercept 
Table 21. Na and $\mathrm{Mg}$ in "mixed" rain samples

\begin{tabular}{|c|c|c|c|c|c|c|c|c|c|}
\hline Sample & Date & $\begin{array}{c}\text { Sample } \\
\text { Type }\end{array}$ & $\begin{array}{r}\mathrm{h} \\
\mathrm{cm}\end{array}$ & ${ }^{\mathrm{Na}} \mathrm{mc}$ & $\mathrm{Mg}$ & $\begin{array}{l}\mathrm{Na} \\
\text { Total } \\
\mu \mathrm{g} / \mathrm{Cm}^{2} \text {. }\end{array}$ & $\begin{array}{l}\mathrm{Mg} \\
\text { position } \\
\text { rain }\end{array}$ & $\begin{array}{l}\mathrm{Mg} / \\
\mathrm{Na}\end{array}$ & $\begin{array}{l}\text { Wind } \\
\text { Miles/hour }\end{array}$ \\
\hline S/L18 & $\begin{array}{c}4 / 24-26 \\
76\end{array}$ & $T M$ & 1.03 & $\begin{array}{c}1.23 \\
\pm 0.057\end{array}$ & $\begin{array}{r}0.224 \\
\pm 0.000\end{array}$ & $\begin{array}{c}1.19 \\
\pm 0.059\end{array}$ & $\begin{array}{l}0.216 \\
\pm 0.00\end{array}$ & 0.18 & 20 \\
\hline$S / L 41^{a}$ & $\begin{array}{r}5 / 21 / \\
76\end{array}$ & $\mathrm{RA}^{*}$ & 0.520 & $\begin{array}{r}0.900 \\
\pm 0.100\end{array}$ & $\begin{array}{r}0.200 \\
\pm 0.020\end{array}$ & $\begin{array}{r}0.504 \\
\pm 0.056\end{array}$ & $\begin{array}{r}0.112 \\
\pm 0.011\end{array}$ & 0.22 & 11 \\
\hline S/L53 & $\begin{array}{c}6 / 1-2 / \\
76\end{array}$ & $R A^{*}$ & 1.45 & $\begin{array}{r}0.380 \\
\pm 0.040\end{array}$ & $\begin{array}{r}0.060 \\
\pm 0.006\end{array}$ & $\begin{array}{r}0.509 \\
\pm 0.051\end{array}$ & $\begin{array}{r}0.080 \\
+0.008\end{array}$ & 0.16 & 13.3 \\
\hline Mean & - & - & $\begin{array}{c}1.0 \\
\pm 0.466\end{array}$ & $\begin{array}{r}0.837 \\
\pm 0.429\end{array}$ & $\begin{array}{r}0.161 \\
\pm 0.089\end{array}$ & $\begin{array}{r}0.759 \\
\pm 0.437\end{array}$ & $\begin{array}{r}0.141 \\
\pm 0.079\end{array}$ & $\begin{array}{r}0.19 \\
\pm 0.03\end{array}$ & $\begin{array}{l}14.8 \\
\pm \quad 4.68\end{array}$ \\
\hline slope & - & - & & 6.78 & 21.1 & - & - & & - \\
\hline Int. & - & - & & 9.09 & 11.4 & - & - & & - \\
\hline $\begin{array}{l}r r . \\
\text { eff. }\end{array}$ & - & - & & 0.621 & 0.400 & - & - & & - \\
\hline
\end{tabular}

$T=$ Total fallout, $R=$ Rain

$M=$ Manually collected sample; $A=$ Sample collected using the automatic rain dry fallout collector

* Thunderstorm

a Thundershower occurred within one hour (15:00-16:00) on 5/21. 
Table 22. $\mathrm{Na}$ and $\mathrm{Mg}$ in "land" rain samples

\begin{tabular}{|c|c|c|c|c|c|c|c|c|c|}
\hline \multirow{2}{*}{ Sample } & \multirow[t]{2}{*}{ Date } & \multirow{2}{*}{$\begin{array}{l}\text { Sample } \\
\text { Type }\end{array}$} & \multirow{2}{*}{$\begin{array}{l}\mathrm{h} \\
\mathrm{cm}\end{array}$} & $\mathrm{Na}$ & $\mathrm{Mg}$ & Na & Mg & $\mathrm{Mg} /$ & Wind \\
\hline & & & & \multicolumn{2}{|c|}{$\mathrm{mg} / 1$} & \multicolumn{2}{|c|}{$\begin{array}{l}\text { Total deposition } \\
\mu \mathrm{a} / \mathrm{cm}^{2} \text { rain }\end{array}$} & & \\
\hline L4 & $\begin{array}{c}12 / 17 / \\
75\end{array}$ & TM & 1.4 & $\begin{array}{l}1.92 \\
\pm 0.010\end{array}$ & $\begin{array}{r}0.260 \\
\pm 0.010\end{array}$ & $\begin{array}{l}1.03 \\
\pm 0.043\end{array}$ & $\begin{array}{r}0.143 \\
\pm 0.003\end{array}$ & 0.14 & 14.0 \\
\hline 113 & $\begin{array}{c}4 / 16 / \\
76\end{array}$ & RA & 0.25 & $\begin{array}{r}0.650 \\
\pm 0.065\end{array}$ & $\begin{array}{r}0.350 \\
\pm 0.035\end{array}$ & $\begin{array}{r}0.163 \\
\pm 0.016\end{array}$ & $\begin{array}{r}0.086 \\
\pm 0.009\end{array}$ & 0.53 & 12.0 \\
\hline$L 16$ & $\begin{array}{l}4 / 22- \\
23 / 76\end{array}$ & RM & 0.35 & $\begin{array}{l}1.00 \\
+0.060\end{array}$ & $\begin{array}{r}0.300 \\
+0.010\end{array}$ & $\begin{array}{r}0.350 \\
+0.021\end{array}$ & $\begin{array}{r}0.105 \\
+0.004\end{array}$ & 0.30 & 13.3 \\
\hline L19 & $\begin{array}{c}4 / 26-27 \\
76\end{array}$ & RM & 0.08 & $\begin{array}{r}0.380 \\
\pm 0.040\end{array}$ & $\begin{array}{r}0.200 \\
\pm 0.020\end{array}$ & $\begin{array}{r}0.029 \\
\pm 0.003\end{array}$ & $\begin{array}{r}0.015 \\
\pm .002\end{array}$ & 0.52 & 15.0 \\
\hline L2O & $\begin{array}{c}4 / 27-28 \\
76\end{array}$ & RM & 0.30 & $\begin{array}{r}0.250 \\
\pm 0.046\end{array}$ & $\begin{array}{r}0.046 \\
\pm 0.003\end{array}$ & $\begin{array}{r}0.075 \\
\pm 0.014\end{array}$ & $\begin{array}{r}0.014 \\
\pm 0.001\end{array}$ & 0.18 & 13.4 \\
\hline L47 & $\begin{array}{r}5 / 27 / \\
76\end{array}$ & $R A^{*}$ & 0.04 & $\begin{array}{l}2.00 \\
\pm 0.200\end{array}$ & $\begin{array}{r}0.440 \\
\pm 0.044\end{array}$ & $\begin{array}{r}0.085 \\
\pm 0.009\end{array}$ & $\begin{array}{r}0.019 \\
\pm 0.002\end{array}$ & 0.22 & 8.0 \\
\hline Mean & - & - & $\begin{array}{r}0.40 \\
\pm 0.50\end{array}$ & $\begin{array}{l}1.03 \\
\pm 0.763\end{array}$ & $\begin{array}{r}0.266 \\
\pm 0.135\end{array}$ & $\begin{array}{r}0.289 \\
\pm 0.380\end{array}$ & $\begin{array}{r}0.064 \\
\pm 0.055\end{array}$ & $\begin{array}{r}0.315 \\
\pm 0.171\end{array}$ & $\begin{array}{l}12.6 \\
\pm 2.46\end{array}$ \\
\hline Slope & & & & -1.79 & -12.8 & - & - & - & - \\
\hline Int. & & & & 14.5 & 16.0 & - & - & - & - \\
\hline $\begin{array}{l}\text { Corr. } \\
\text { Coeff. }\end{array}$ & - & - & - & -0.553 & -0.703 & 0.277 & 0.257 & - & - \\
\hline
\end{tabular}

\footnotetext{
$T=$ Total fallout

$R=$ Rainfall

$M=$ Manually collected samples

$A$ = Samples collected using the automatic rain-dry fallout sample Thunderstorm occurred only within 5 minutes.
}

Form of regression equation:

wind $=$ (slope $X$ rain concentration) + intercept 
IV. DISCUSSION

A. The Rate and Processes of Removal of Atmospheric Sea Salt

1. Dry Removal of Atmospheric Sea Salt

a. The rate of dry fallout and atmospheric concentrations of $\mathrm{Na}$ and $\mathrm{Mg}$ for samples collected in the "marine", "mixed" and "1and" subenvironments of the Coastal R.I. environment

The means of the rates of dry fallout in $9 \times 10^{-12} / \mathrm{cm}^{2} / \mathrm{sec}$ and atmospheric concentration in $u g / \mathrm{m}^{3}$ for $\mathrm{Na}$ and $\mathrm{Mg}$ collected in the 3 subenvironments of coastal R.I. environment are shown in Table 23. Values obtained from "corrected to marine" samples are also included. As expected, these data indicates clearly that the ocean is the major source of atmospheric $\mathrm{Na}$ and $\mathrm{Mg}$ in coastal Rhode Island. Sea salt particles produced by bubbles bursting at the ocean surface are carried by the prevailing winds in the atmosphere. Since they have residence 
Table 23. Summary table for rain and dry fallout samples collected in coastal Rhode Island*

Sample Mean Rate of Mean Mean Atmospheric conc. Mean Mean conc. Mean Type dry fallout $\frac{\mathrm{Na} \mathrm{Mg}}{\mathrm{Ma}}$ $\left(\mathrm{gm} \times 10^{-12} / \mathrm{cm}^{2} \mathrm{sec}\right)$

$\mathrm{Mg} / \mathrm{Na}$

Na $3 j^{\mathrm{Mg}}$ $\left(\mu \mathrm{g} / \mathrm{m}^{3}\right)$ of rainfall

\begin{tabular}{|c|c|c|c|c|c|c|c|c|c|}
\hline 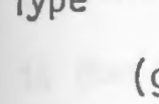 & $\stackrel{\mathrm{Na}}{\times 10^{-12}}$ & $\frac{\mathrm{Mg}}{\left(\mathrm{cm}^{2} \mathrm{sec}\right)}$ & $\mathrm{Mg} / \mathrm{Na}$ & ${ }^{\mathrm{Na}}(\mu \mathrm{g}$ & $\mathrm{Mg}$ & $\mathrm{Mg} / \mathrm{Na}$ & ${ }_{\text {(mg }}^{\mathrm{Na}}$ & $1 /)^{\mathrm{Mg}}$ & $\mathrm{Mg} / \mathrm{Na}$ \\
\hline Marine & 3.58 & 0.573 & 0.16 & 1.24 & 0.177 & 0.17 & 1.62 & 0.238 & 0.15 \\
\hline $\begin{array}{l}\text { Correc- } \\
\text { ted-to- } \\
\text { marine }\end{array}$ & 2.83 & 0.579 & 0.20 & 2.41 & 0.426 & 0.18 & - & - & \\
\hline Mixed & 1.11 & 0.318 & 0.30 & 0.786 & 0.151 & 0.22 & 0.837 & 0.161 & 0.19 \\
\hline Land & 0.260 & 0.215 & 1.1 & 0.055 & 0.042 & 0.79 & 1.03 & 0.266 & 0.32 \\
\hline
\end{tabular}

* For standard deviations of the mean see individual data tables. 
times of a few minutes to a few days depending upon their size, (Junge, 1963), they are ultimately removed from the atmosphere by dry fallout and rainfall to the ocean surface, coastal areas and some smaller fraction to infand zones. The higher dry removal rates and atmospheric concentrations shown for "mixed" samples compared to "land" samples is due to the marine fractions in these samples. This is clearly demonstrated by the fact that "corrected-to-marine" samples show values comparable to marine samples.

The correlation coefficients for the rates of dry fallout or atmospheric concentration for $\mathrm{Na}$ or $\mathrm{Mg}$ versus wind speed are above 0.80 for the "marine"samples category (Table 12). These are significant correlations at the $1 \%$ level, i.e. a $99 \%$ probability that a real correlation exists between these variables (Fisher 1958). A plot of wind speed versus the atmospheric concentrations and wind speed versus the rate of dry fallout for $\mathrm{Na}$ and $\mathrm{Mg}$ are shown in Fig. 7-8 respectively. The regression equations for the resulting lines obtained in Fig. 7 and Fig. 8 are:

Atmospheric concentrations $\left(\mathrm{hg} / \mathrm{m}^{3}\right)$ versus wind speed (miles/ hour)

$$
\begin{aligned}
& \text { Wind }=5.5 \times \mathrm{Na}+6.0 \\
& \text { Wind }(s)_{(s)}=50 \times \mathrm{Mg}+4.1
\end{aligned}
$$

Rate of dry fallout $\left(10^{-12} \mathrm{gcm}^{-2} \mathrm{sec}^{-1}\right.$ versus wind speed (miles/hour)

$$
\begin{aligned}
& \text { Wind }(s)=2.0 \times \mathrm{Na}+5.1 \\
& \text { Wind }(s)=15 \times \mathrm{Mg}+4.1
\end{aligned}
$$

The intercepts in these equations represent the wind speed in miles/ hour at which $\mathrm{Na}$ and $\mathrm{Mg}$ rate of dry fallout or atmospheric concentration are equal to zero. This zero $\mathrm{Na}$ or $\mathrm{Mg}$ intercept may be explained as the minimum wind speed above which white caps (which produce the atmos- 
Figure 7. Atmospheric $\mathrm{Na}$ and $\mathrm{Mg}$ concentration vs. wind speed ("marine" samples). 


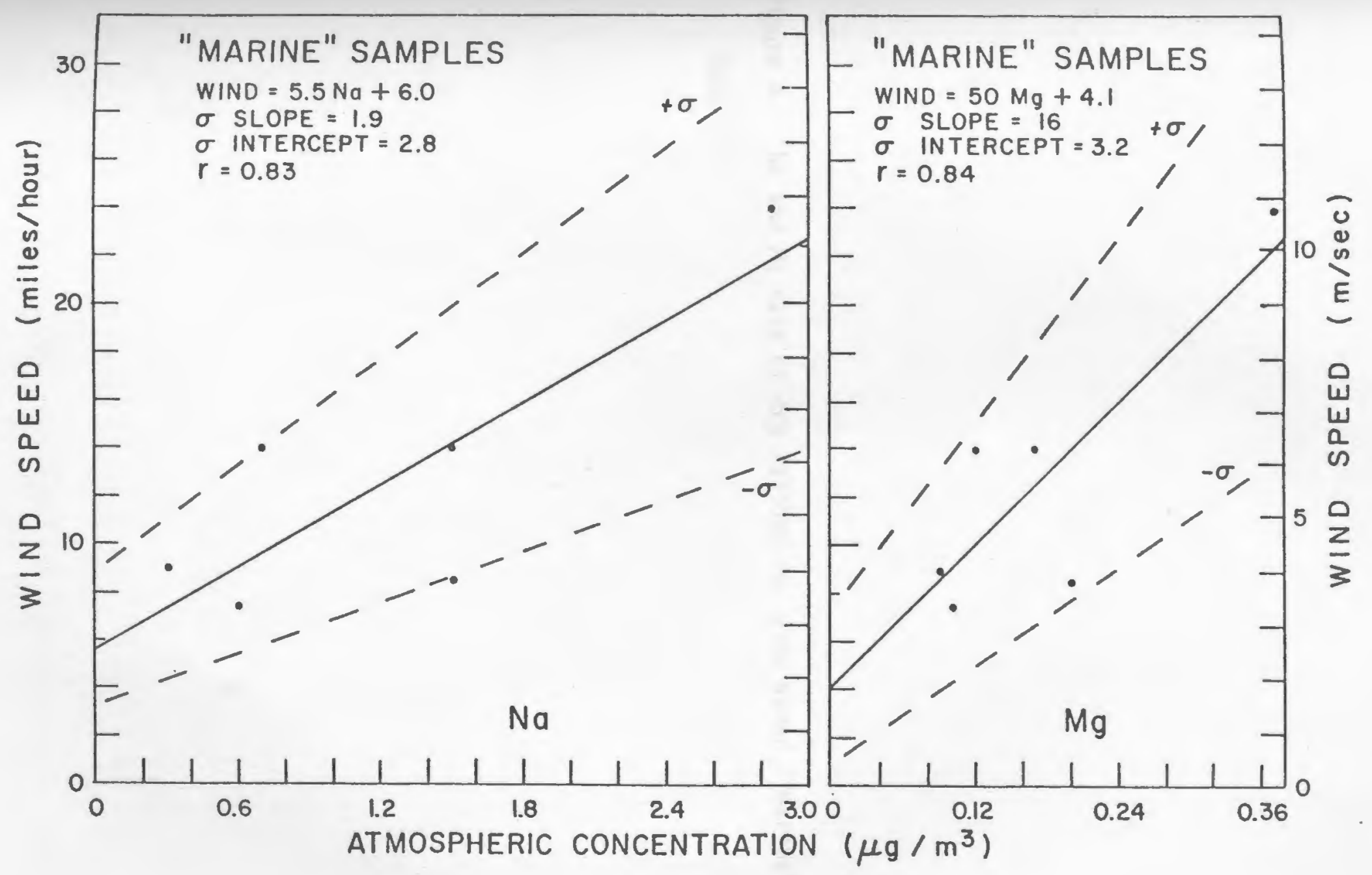


Figure 8. $\mathrm{Na}$ and $\mathrm{Mg}$ rate of dry fallout vs. wind speed ("marine" samples). 


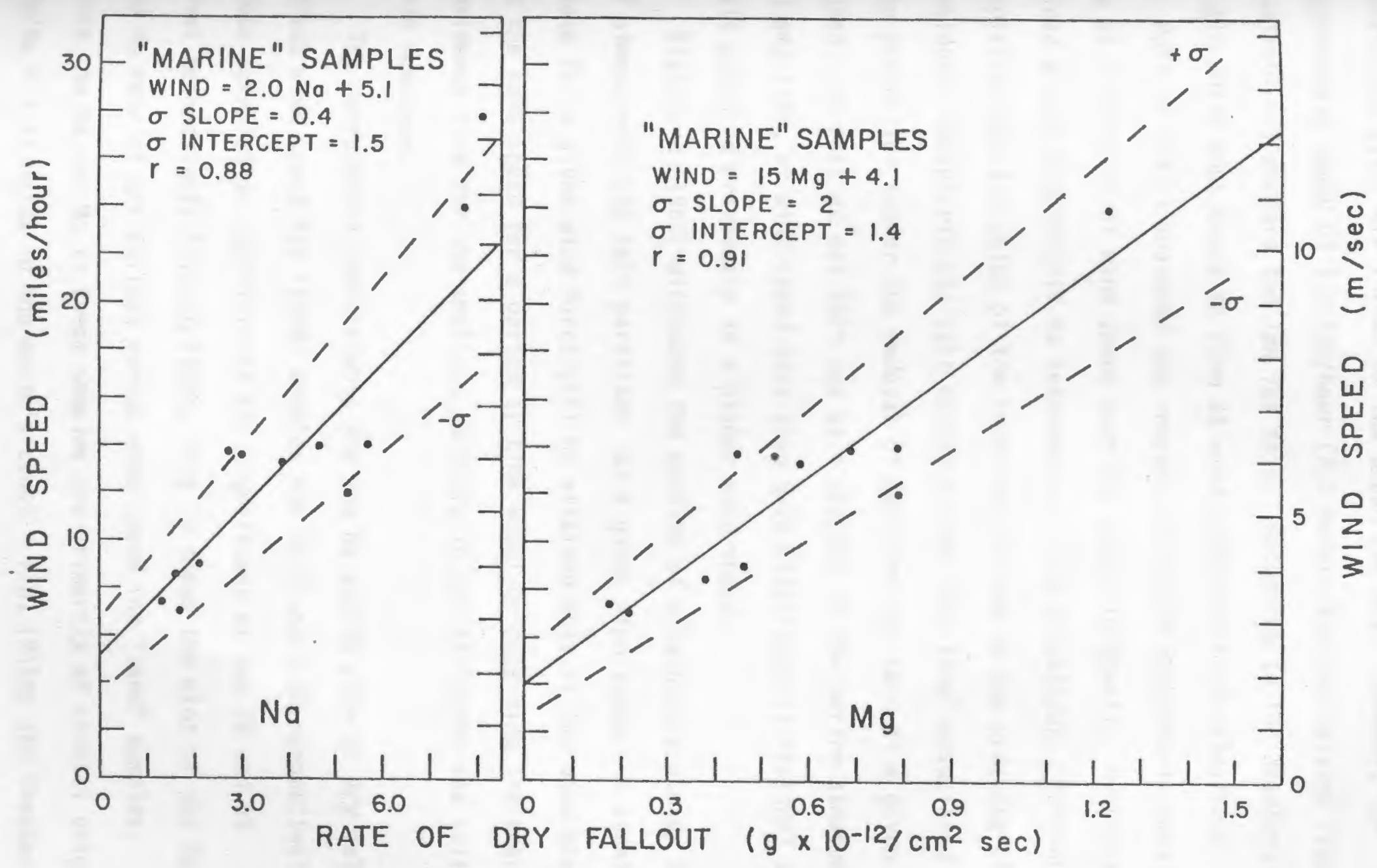


pheric sea salt) are formed on the ocean surface. However, the approximate speed of $5 \mathrm{miles} /$ hour $(2.2 \mathrm{~meters} / \mathrm{sec}) \mathrm{calculated}$ from equations 4-7 appears too low for this. According to the Beaufort wind scale white caps begin to form at wind speeds of 8-12 miles/hour. G. Hoffman (1971) measured the concentrations of atmospheric particulate $\mathrm{Na}$ as a function of wind speed over the ocean in Hawai i. He determined a zero atmospheric $\mathrm{Na}$ intercept of $\sim 5.5 \mathrm{miles} / \mathrm{hour}$. Hoffman explained the low value of the intercept as due to the presence of residual atmospheric sea salt caused by the "lag time" associated with the production and/or the removal of maritime sea salt at a given wind speed. He pointed out that sea salt present in the marine atmosphere, at any time, at wind speed less than 8-12 miles/hour is residual sea salt produced previously at a higher wind speed.

Blanchard (1963) discussed the problem of attaining a steady state of atmospheric sea salt particles at a given wind speed. A steady state for a given wind force will be attained only if the wind blows at the same speed for a period of time equal or exceeding the average residence time for the smallest particle in the air-borne sea salt size spectrum.

The correlation coefficients for the $\mathrm{Na}$ and $\mathrm{Mg}$ rate of dry fallout versus wind speed for "1and" samples are 0.75 and 0.60 respectively. These correlation coefficients are significant at the $2 \%$ and $5 \%$ level respectively (Fisher, 1958). Fig. 9 shows the plot of the $\mathrm{Na}$ and Mg rate of dry fallout versus wind speed for "land" samples. Since the $\mathrm{Na}$ and $\mathrm{Mg}$ in these samples are primarily of crustal origin $(\mathrm{Mg} / \mathrm{Na}=1.1 ; \mathrm{Mg} / \mathrm{Na}$ in the earth's crust $=1.0$, (Riley and Chester 1971), it is likely that the higher the wind force over land the more crustal 
Figure 9. $\mathrm{Na}$ and Mg rate of dry fallout vs. wind speed ("land samples). 


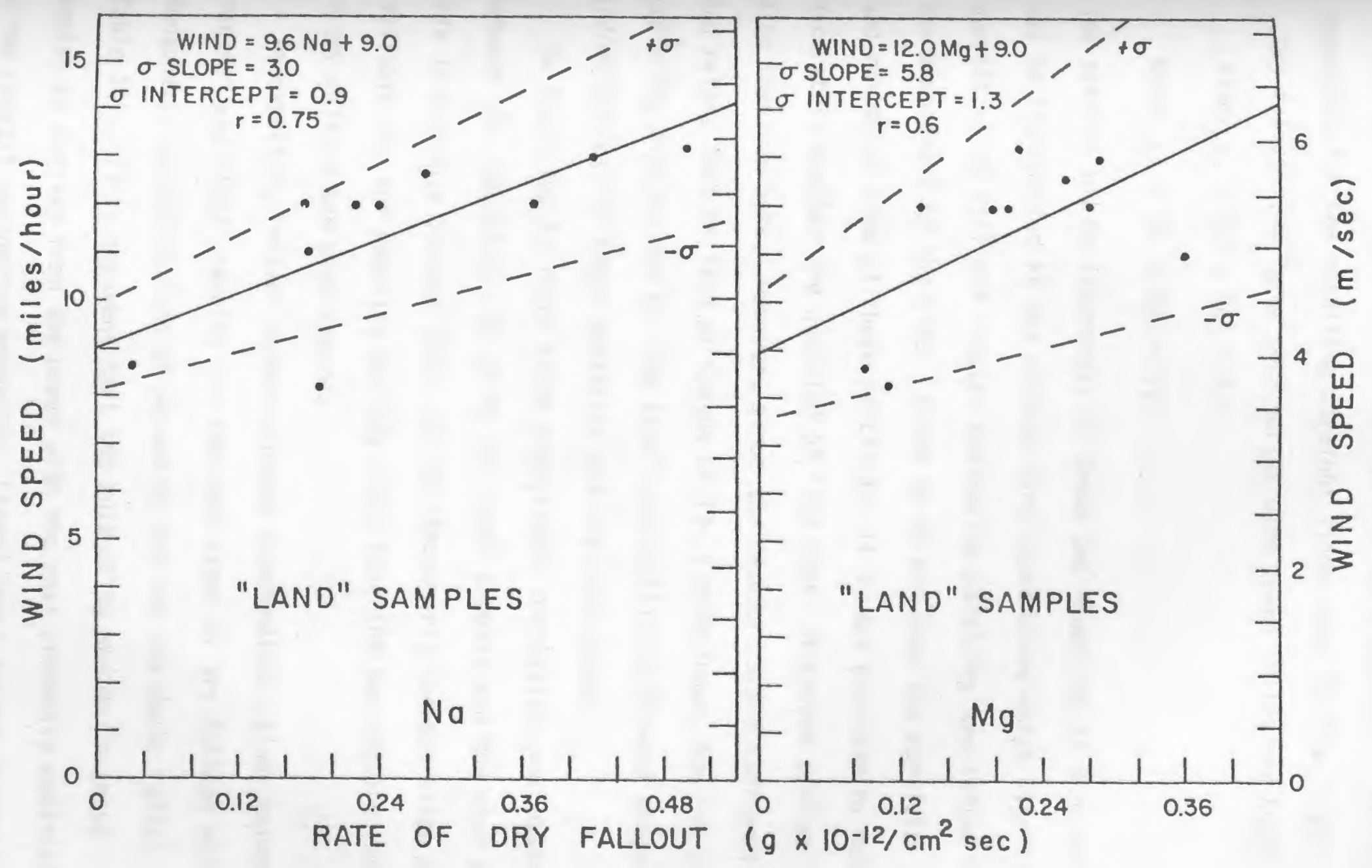


Na and Mg particles become suspended in the atmosphere. The regression equations for the resulting straight lines shown in Fig. 9 are:

Dry fallout $\left(10^{-12} \mathrm{~g} / \mathrm{cm}^{2} \mathrm{sec}\right)$ versus wind speed (miles per hour)

$$
\begin{aligned}
& \text { Wind }(L)=9.6 \times \mathrm{Na}+9.0 \\
& \text { Wind }(L)=12 \times \mathrm{Mg}+9.0
\end{aligned}
$$

The zero $\mathrm{Na}$ and $\mathrm{Mg}$ intercepts in these two equations at $9 \mathrm{miles} / \mathrm{hour}$ may be interpreted as the mininum wind speed above which significant quantities of soil and crustal weathering particles are lifted into the atmosphere by the wind. Since we do not know the particle size and residence time of these particles, it is not possible to determine accurately whether the question of "lag time" discussed earlier is also involved here. However, since the Beaufort scale indicates that wind raises dust on land at speeds of 13-18 miles/hour, the low intercepts may also be due to "lag time" and equilibria between production and/or removal of these particles and the wind speed.

As indicated in Table 13 no significant correlation was observed between the atmospheric $\mathrm{Na}$ or $\mathrm{Mg}$ in "land" samples and the wind speed. This is probably because there are no atmospheric concentration samples available for the sampling periods which have the two highest rates of dry fallout and wind speeds.

As expected, "mixed" samples showed intermediate values between "marine" and "land" samples for the mean rates of dry fallout and atmospheric concentrations of $\mathrm{Na}$ and $\mathrm{Mg}$ and for the $\mathrm{Mg} / \mathrm{Na}$ ratios (Table 14). It is apparent that the bulk of $\mathrm{Mg}$ and $\mathrm{Na}$ in these samples is derived from the ocean with the rest primarily contributed by the crustal weathering products. Linear least square regression analysis for this category of samples showed that the only significant 
correlation (1\%) was between $\mathrm{Na}$ dry fallout and wind speed. The correlation coefficient between Mg dry fallout and wind speed is significant at only the $10 \%$ level i.e. ( $90 \%$ probability that a real correlation exists, Fisher 1958).

In an attempt to look at these marine fractions of "mixed" samples, the "mixed" samples were "corrected-to-marine" as described in Chapter III (Table 15). Linear least square regression analysis showed that correlations between the corrected rates of dry fallout, corrected atmospheric $\mathrm{Na}$ and $\mathrm{Mg}$ with corrected wind speeds were very significant ( $1 \%$ leve 1$)$. The linear regression equations for wind speed versus the $\mathrm{Na}$ and $\mathrm{Mg}$ rate of dry fallout and atmospheric concentrations can be derived from the slopes and intercepts given in Table 15.

For a tmospheric concentrations $\left(\mu \mathrm{g} / \mathrm{m}^{3}\right)$ versus wind speed ( $\mathrm{mi}$ les/hour)

$$
\begin{aligned}
& \text { Wind }_{(C)}=2.2 \times \mathrm{Na}+10 . \\
& \text { Wind }(c)=11 \times \mathrm{Mg}+11
\end{aligned}
$$

For the rates of dry fallout $\left(10^{-12} \mathrm{~g} / \mathrm{cm}^{2} \mathrm{sec}\right)$ versus wind speed (miles/hour)

$$
\begin{aligned}
& \text { Wind }(C)=2.7 \times \mathrm{Na}+4.9 \\
& \text { Wind }(C)=8.6 \times \mathrm{Mg}+8.2
\end{aligned}
$$

If we compare these equations with equations $6,7,8$ and 9 derived for "marine" samples, it seems that only the $\mathrm{Na} /$ wind equations are comparable to each other. It is interesting, however, to observe that for the combined "marine" and "corrected-to-marine" samples significant correlations were observed between both dry fallout and atmospheric concentrations versus wind speed for both $\mathrm{Na}$ and $\mathrm{Mg}$ (see Table 16). This suggests that the assumptions behind the calculation of the "corrected-to-marine" rates of dry fallout and atmospheric concentration 
for $\mathrm{Na}$ and perhaps $\mathrm{Mg}$ may be valid. A plot of wind speed versus the atmospheric concentrations and wind speed versus the rate of dry fallout for $\mathrm{Na}$ and $\mathrm{Mg}$ in the "marine" plus "corrected-to-marine" sample populations combined are shown in Figs. 10-11.

b. "Mixed" samples collected within the 010-090 wind sector Although samples collected within the wind sector $010-090^{\circ}$ are essentially "mixed" samples, they appear to show a different trend than the rest of the samples. Since they merit special discussion they are listed separately in Table 17. As shown, it seems that the rates of dry fallout and atmospheric concentrations of $\mathrm{Na}$ and $\mathrm{Mg}$ in these samples are not related to wind speed. Although the wind speeds recorded while sampling these samples were quite variable, the differences in the rate of dry removal and atmospheric concentrations are negligible. As can be seen from the map of sampling sectors (Fig. 5), wind blowing within the sector $010-090^{\circ}$ can be considered to bring marine air masses which have travelled over land for 2150 kilometers (100 miles). The constancy of the rate of dry fallout and atmospheric concentration of $\mathrm{Na}$ and $\mathrm{Mg}$ and their non-dependence on wind speed may suggest that the decrease in the rate of dry removal and atmospheric concentrations of sea salt as we go inland is not continually linear. It is likely that most of the sea salt produced by the ocean is removed very rapidly and is primarily deposited in the coastal zones. Sea salt particles of smaller size and longer residence time are possibly carried further inland. As shown in Table 17, the mean rate of $\mathrm{Na}$ dry fallout for samples collected in this sector is $\sim 1.5 \times 10^{-12} \mathrm{~g} / \mathrm{cm}^{2} \mathrm{sec}$ at a mean wind speed of $12.5 \mathrm{miles} / \mathrm{hour}$. If 
Figure 10. Atmospheric $\mathrm{Na}$ and $\mathrm{Mg}$ concentration vs. wind speed ("marine" and "corrected-to-marine" samples). 


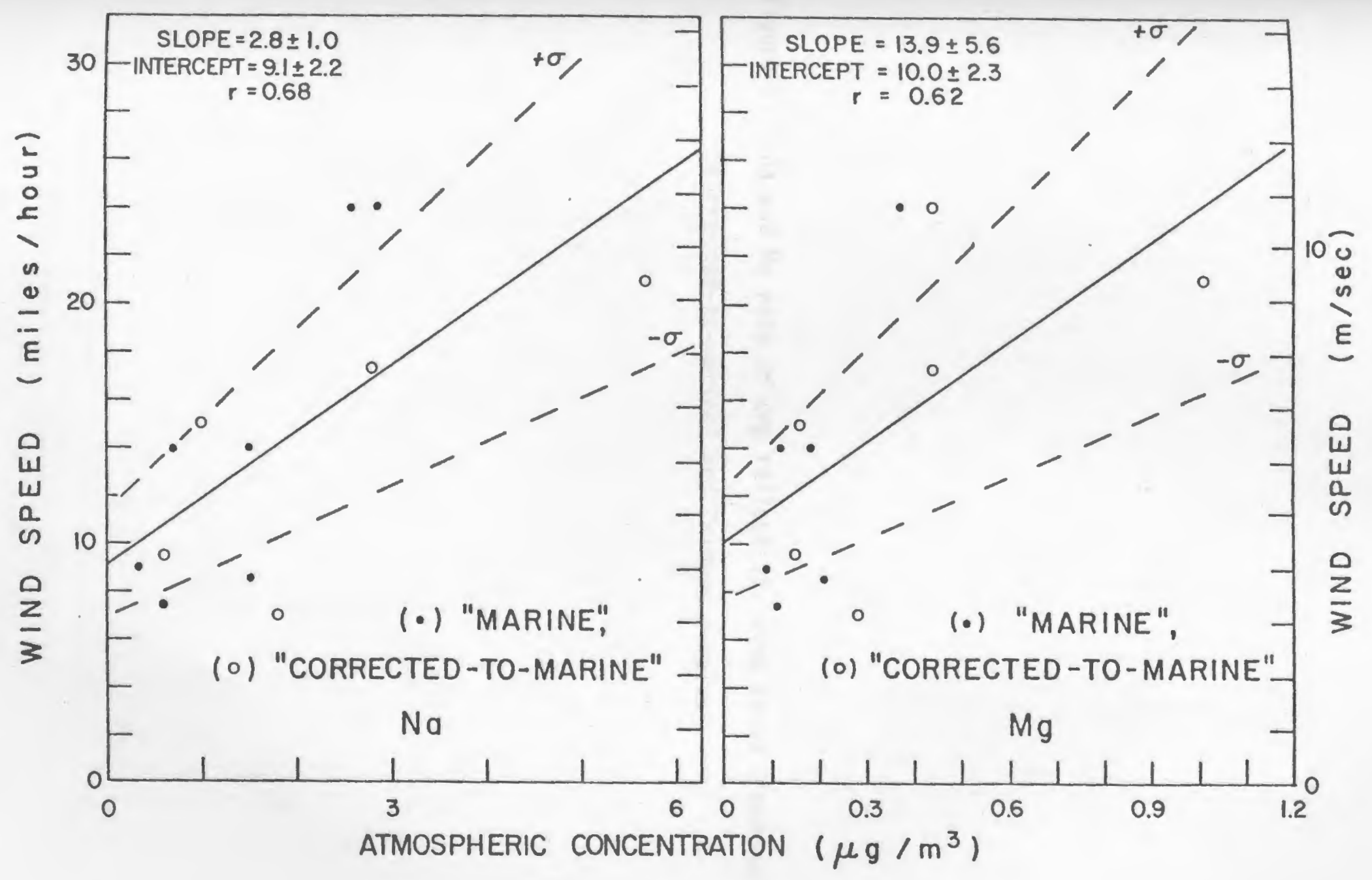


Figure 11. Na and Mg rate of dry fallout vs. wind speed ("marine", "corrected-to-marine" and Trident samples). 


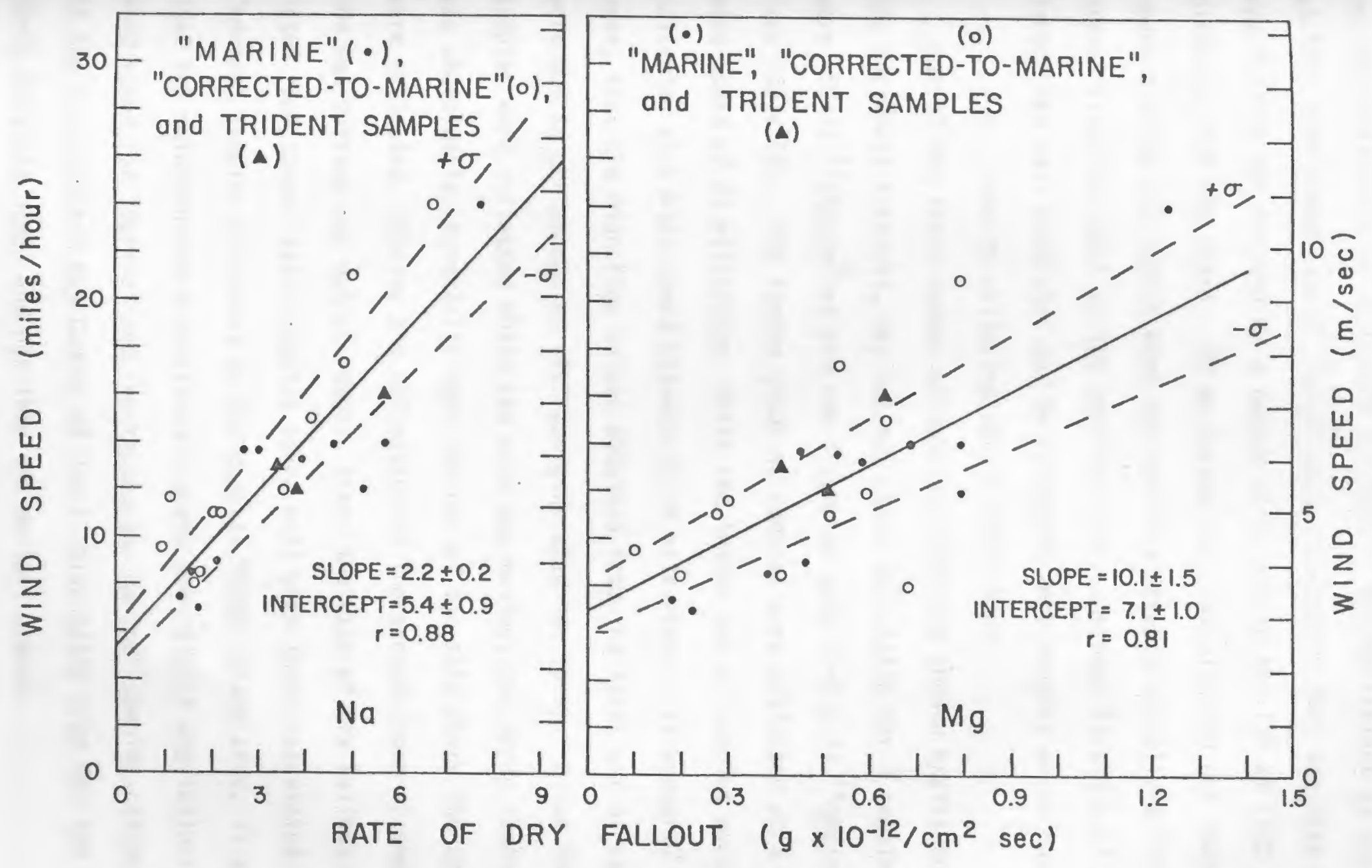


we use equation 6 to calculate the rate of $\mathrm{Na}$ dry fallout at the coast at this wind speed $\left(23 \times 10^{-12} \mathrm{~g} / \mathrm{cm}^{2} \mathrm{sec}\right)$, it appears that the rate of $\mathrm{Na}$ dry fallout has dropped by a factor of $\sim 2$ within the $150 \mathrm{Km}$ (100 miles) distance from the coast. If we assume that the wind did not change speed and the air masses were not modified meteorologically during their travel from the coast to the sampling site, the mean lifetime of the larger sea salt particles may be estimated very roughly as w hours or less.

\section{c. Samples collected aboard R/VTrident}

Out of the total number of samples collected aboard R/VTrident over the northwest Atlantic, dry fallout rates calculated for 4 samples were $\sim 50 \times 10^{-12} \mathrm{gNa} / \mathrm{cm}^{2} \mathrm{sec}$ and for 3 samples were $\sim 3-6 \times 10^{-12} \mathrm{gNa} / \mathrm{cm}^{2} \mathrm{sec}$ (see Table 18). The former group of samples were collected at a mean wind speed of 24 miles/hour, while the latter set of samples were collected at a wind speed between 12-16 miles/hour. It appears, however, that the high flux values obtained from the first set of samples were due to contamination with bow generated sea spray. Since these samples were collected while the ship was moving, sea spray contamination was unavoidable, especially near the bow of the ship where the samples were collected. During the collection of the second group of samples, the sea surface was not as rough. Since the rate of dry fallout calculated from these latter samples agree well with those calculated from "marine" samples collected at the coastal Rhode Island site, it appears that the relationship established between the rate of dry fallout and wind speed for "marine" and "corrected-to-marine" samples collected at the Narragansett Bay Campus of U.R.I. also holds true for the open North Atlantic ocean and possibly the world's oceans.

d. The $\mathrm{Mg} / \mathrm{Na}$ ratios

The mean $\mathrm{Mg} / \mathrm{Na}$ ratio of 0.16 for "marine" samples approaches the 
sea water ratio of 0.12 . The excess $M g$ is possibly due to vertical mixing of the air masses with consequent addition of crustal Mg from continental sources. This probably happens when the marine air masses enter coastal areas. This explanation is further supported by the $\mathrm{Mg} / \mathrm{Na}$ ratios observed for samples collected aboard R/VTrident over the North Atlantic Ocean (Table 18 ). The mean $\mathrm{Mg} / \mathrm{Na}$ ratio calculated from 3 samples where both $\mathrm{Mg}$ and $\mathrm{Na}$ were analysed was found to be 0.126 , very close to the sea water ratio of 0.12 . On the other hand "land" samples showed a mean $\mathrm{Mg} / \mathrm{Na}$ ratio of 1.1 for the dry fallout and 0.79 for the atmospheric samples (Table 13). This is almost identical to the $1.0 \mathrm{Mg} / \mathrm{Na}$ ratio in the earth crust (Riley and Chester 1971). This suggests that the major fraction of the $\mathrm{Mg}$ and $\mathrm{Na}$ in these samples is of crustal origin.

As expected "mixed" samples showed an intermediate $\mathrm{Mg} / \mathrm{Na}$ ratio ( $20.2-0.3)$ between the "marine" and "land" samples. Since this is considerably closer to the sea water $\mathrm{Mg} / \mathrm{Na}$ ratio than the crustal $\mathrm{Mg} / \mathrm{Na}$ ratio, it suggests that the source of the main bulk of the $\mathrm{Na}$ and $\mathrm{Mg}$ in these samples is the ocean.

As described earlier the mean $\mathrm{Mg} / \mathrm{Na}$ ratio observed for samples collected aboard R/VTrident was found to be almost identical to the sea salt ratio. Since these samples were collected at a mid-ocean location, where contamination of the marine aerosol with crustal particles is minimal, this suggests that there is little chemical fractionation of sea salt $\mathrm{Mg}$ in the marine environment. Several investigators have reported that the $\mathrm{Mg}$ and other alkali and alkaline earth metals are enriched relative to $\mathrm{Na}$ in sea salt aerosols due to chemical fractionation of these particles when they are produced by bubbles 
bursting at the sea surface (eg. see Sugawera et al. 1949; Koyama and Sugawara 1953, Oddie 1960, Komabayasi 1962, Chesselet et al.,1972, Buat-Menard et al.,974). This subject was reviewed recently by Duce and Hoffman (1976); Hoffman et al., (1977). Observed enrichment of $\mathrm{Mg}$ and other alkali and alkaline earth metals relative to $\mathrm{Na}$ in environmental samples was found to result from the addition of non-sea salt particles, particularly crustal particles to these samples.

e. Deposition velocities for particulate $\mathrm{Na}$ and $\mathrm{Mg}$

The mean deposition velocities $\left(v_{g}\right)$ calculated from the 3 different subenvironments of Rhode Island coast and "corrected-to-marine" samples are $2.4 \pm 1.6 \mathrm{~cm} / \mathrm{sec}$ for $\mathrm{Na}$ and $3.0 \pm 1.6 \mathrm{~cm} / \mathrm{sec}$ for $\mathrm{Mg}$ (Table 19). Cawse et al. $(1972,1974)$ determined $V_{g}$ for $\mathrm{Na}$ to range from $0.21-3.4 \mathrm{~cm} / \mathrm{sec}$.

2. Wet Removal of Atmospheric Sea Salt

a. Rainfall collected from different wind sectors

Out of the 17 rain showers collected during this project, 8 were classified as "marine", 6 were "land" and 3 were "mixed", depending on the wind direction during the rainfall. The mean concentrations of $\mathrm{Na}$ and $\mathrm{Mg}$ in rain water and the mean amounts of $\mathrm{Na}$ and $\mathrm{Mg}$ deposited in $\mathrm{ug} / \mathrm{cm}^{2}$ for each subenvironement are given in Tables $20,21,22$ and summary Table 23. As shown by these data most of the $\mathrm{Na}$ and $\mathrm{Mg}$ removed by rainfall originated in the ocean (see Tables $20,21,22$ ). When the $\mathrm{Na}$ concentration and the total amount of rainfall are considered, more sea salt is removed by "marine" and "mixed" rain than by rain occurring when the wind is blowing off land. As would be expected linear least square regression analysis between wind speeds and concentrations of $\mathrm{Na}$ and $\mathrm{Mg}$ in rainfall showed significant correlations 
for "marine" rains and no significant correlation for "land" and "mixed" rain showers. A plot of wind speed versus $\mathrm{Na}$ and $\mathrm{Mg}$ concentrations in "marine" rain is shown in Fig. 12 . The regression equations for the resulting lines are:

$$
\begin{aligned}
& \text { Wing }(R)=1.9 \times \mathrm{Na}+7.0 \\
& \text { Wind }(R)=14 \times \mathrm{Mg}+7.0
\end{aligned}
$$

Since these rains are marine in origin the $7 \mathrm{miles} /$ hour intercepts may again be considered as the minimum wind speed above which sea salt production occurs at the ocean surface. Since white caps are formed at wind speed between 8-12 miles/hour, in the open ocean, the low intercept of 7 miles/hour may be a result of the "lag time" between production and removal of atmospheric sea salt. This concept was discussed earlier for atmospheric particulate $\mathrm{Na}$ and $\mathrm{Mg}$ concentrations and dry fallout.

The $\mathrm{Na}$ or Mg concentration in "marine" and "mixed" rains in mg/l, showed an inverse relationship with the rain depth in $\mathrm{cm}$ (Fig. 13-14). Since this relationship appears to be logarithmic, it appears washout processes may occur at the very beginning of the rain shower and may be completed very rapidiy. After the completion of washout, the effect of rain is essentially dilution. This relationship was not noticed for "land" rain.

The depth of rainfall (Table 20-22), $h$, in $\mathrm{cm}$, is measured by a standard plastic rain gauge. The amounts of rain represented by $h$ are sometimes higher than the amounts collected by the plastic buckets. This is apparentiy due to evaporation of the rain water in the latter collectors. The mean depth of rainfall for "marine" and "mixed" rain 
Figure 12. $\mathrm{Na}$ and $\mathrm{Mg}$ concentration in rainwater vs. wind speed ("marine" rain). 
(गәs/m) 0JتdS ONIM

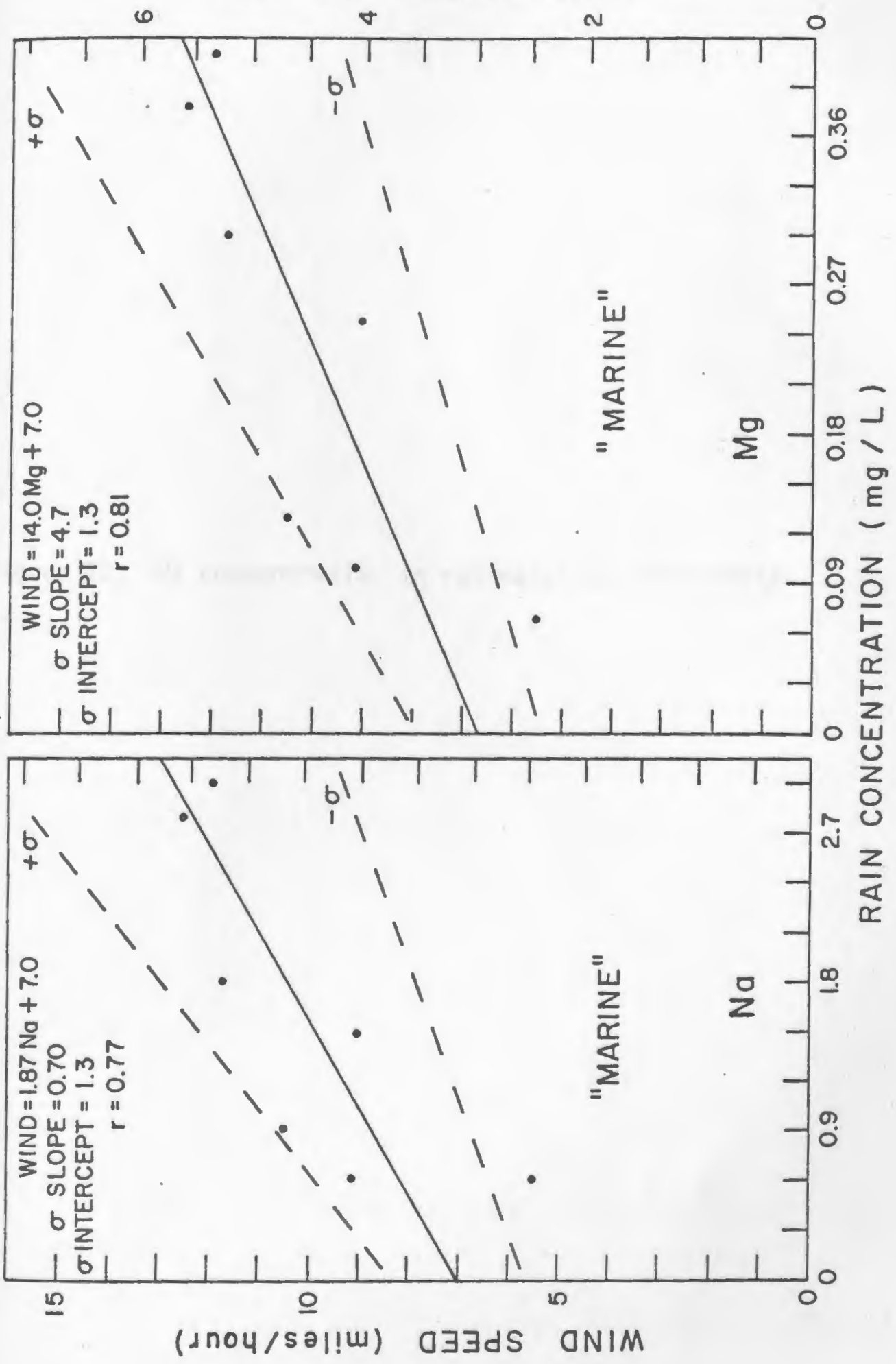


Figure 13. Na concentration in rainwater vs, rain depth. 


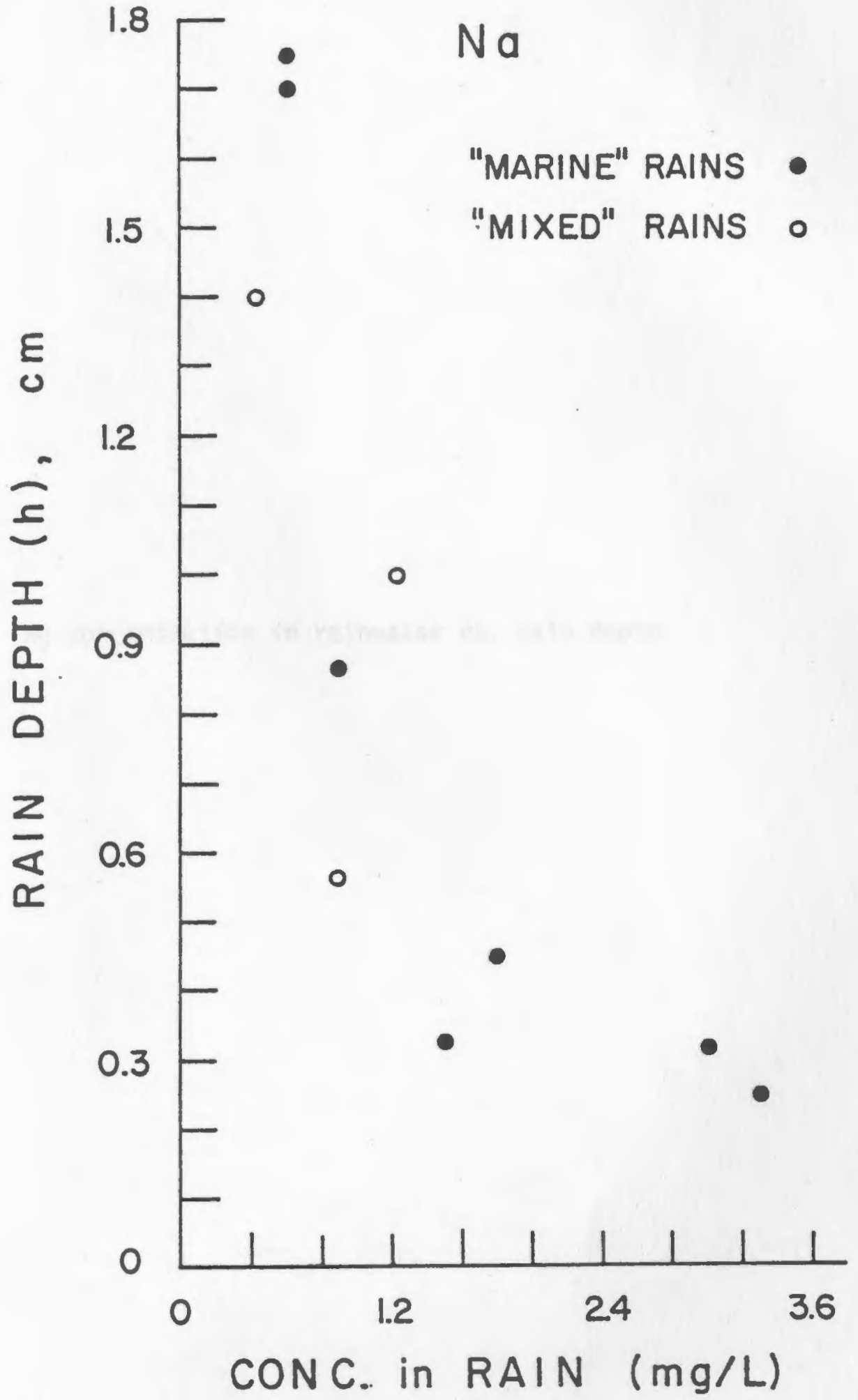


Figure 14. Mg concentration in rainwater vs, rain depth. 


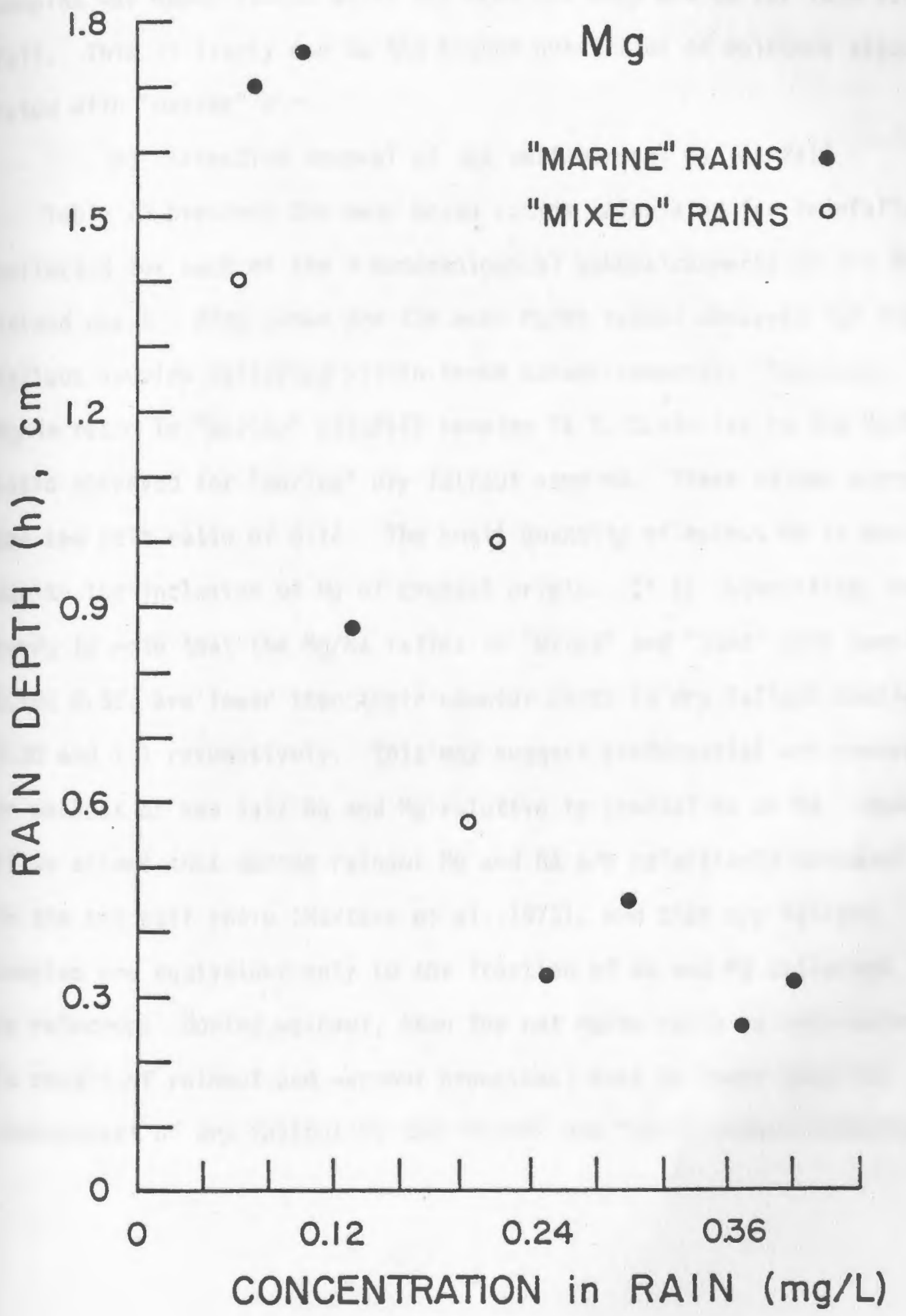


samples was about $1.0 \mathrm{~cm}$, while the mean was only $0.4 \mathrm{~cm}$ for land rainfall. This is likely due to the higher quantities of moisture associated with "marine" air.

b) Selective removal of sea salt aerosol by rainfall

Table 23 presents the mean $\mathrm{Mg} / \mathrm{Na}$ ratios calculated for rainfalls collected for each of the 3 meteorological subenvironments on the Rhode Island coast. Also shown are the mean $\mathrm{Mg} / \mathrm{Na}$ ratios observed for dry fallout samples collected within these subenvironments. The mean $\mathrm{Mg} / \mathrm{Na}$ ratio in "marine" rainfall samples is 0.15 , similar to the $\mathrm{Mg} / \mathrm{Na}$ ratio observed for "marine" dry fallout samples. These values approach the sea salt ratio of 0.12 . The small quantity of excess $\mathrm{Mg}$ is possibly due to the inclusion of Mg of crustal origin. It is interesting, however, to note that the $\mathrm{Mg} / \mathrm{Na}$ ratios in "mixed" and "land" rain samples, $0.19 ; 0.32$, are lower than their counter parts in dry fallout samples, 0.30 and 1.1 respectively. This may suggest preferential wet removal or washout of sea salt $\mathrm{Na}$ and $\mathrm{Mg}$ relative to crustal $\mathrm{Na}$ or $\mathrm{Mg}$. However, if we assume that during rainout $\mathrm{Mg}$ and $\mathrm{Na}$ are selectively consumed in the sea salt ratio (Martens et al.,1973), and that dry fallout samples are equivalent only to the fraction of $\mathrm{Na}$ and $\mathrm{Mg}$ collected by raindrops during washout, then the net $\mathrm{Mg} / \mathrm{Na}$ ratio in rain water (a result of rainout and washout processes) must be lower than its counterpart of dry fallout in the "mixed" and "land" subenvironments. 


\section{B. Geochemistry of Atmospheric Sea Salt}

1. Significance of Wet Removal (rain) of Sea Salt Relative to Dry Deposition in the Coastal Environment of Rhode Island The mean rate of dry fallout and the mean rate of rainfall removal for $\mathrm{Na}$ and $\mathrm{Mg}$ were calculated from the total population of samples collected at the coastal Rhode Island site between 4/15/76 and 6/28/76 (Table 24). As shown, if we compare the mean rate of wet removal (rain) of $\mathrm{Na}$ and $\mathrm{Mg}$ to the mean rate of dry removal during that period of time, it appears that equivalent amounts of $\mathrm{Mg}$ were removed by rainfall and dry fallout and 1.3 as much $\mathrm{Na}$ was removed by rainfall. Since some of the manually collected rainfall samples, especially those collected at inconvenient times, possibly contained a small fraction of dry fallout, the ratio of wet removal (rain) to dry removal of atmospheric $\mathrm{Na}$ and perhaps sea salt is possibly close to one in the coastal environment of Rhode Island. Although this ratio was calculated from samples collected during only one quarter of the year, we will assume for subsequent calculations that the same ratio holds for the entire year. Although only $10.6 \mathrm{~cm}$ of rain fell on the Rhode Island coast during the sampling period between $4 / 15 / 76-6 / 28 / 76$, lower by a factor of two than the amount expected from the mean annual rain depth of $107 \mathrm{~cm}$ (National Weather Service Station, Warwick), it is possible that these rains contained higher sea salt concentrations than the average rains. As shown in Fig. 13-14, the concentrations of $\mathrm{Na}$ or $\mathrm{Mg}$ in rain water are inversely proportional to the depth (or volume) of rain.

2. Sea Salt Yearly Removal Over the World Oceans In order to estimate the rates of wet and dry removal and the annual removal rates of sea salt over the world's oceans, the mean 
rates of dry fallout and rainfall were calculated from the "marine" and "corrected-to-marine" samples as well as samples collected aboard RV/Trident (Table 24). The mean wind speed at which all these samples were collected is approximately $13 \mathrm{miles} /$ hour $(5.5 \mathrm{~m} / \mathrm{sec}$.) (Table 16). Assuming an annual oceanic rain depth of $100 \mathrm{~cm}$ (Baumgartner and Reichel, 1975) and a mean $\mathrm{Na}$ concentration of $1.6 \mathrm{mg} / \mathrm{l}$, (Table 20), the rate of $\mathrm{Na}$ wet (rain) removal from the atmosphere is $5.1 \times 10^{-12} \mathrm{~g} / \mathrm{cm}^{2} \mathrm{sec}$, equivalent to $17 \times 10^{-12} \mathrm{~g}$ sea $\mathrm{salt} / \mathrm{cm}^{2} \mathrm{sec}$. If we compare this figure to the mean rate of dry fallout of $3.3 \times 10^{-12} \mathrm{gNa} / \mathrm{cm}^{2} \cdot \mathrm{sec}$ or $11 \times 10^{-12} \mathrm{~g}$ sea salt $/ \mathrm{cm}^{2} \mathrm{sec}$, it appears that, over the ocean, approximately two thirds of the atmospheric sea salt returns to the ocean in precipitation and approximately one third as dry fallout (Table 24).

If we use the sea salt dry and wet removal rates and integrate over the entire area of the world's oceans, then the total annual removal rate of cyclic sea salt at a mean wind speed of $\sim 20 \mathrm{~km} /$ hour is approximately $30 \times 10^{14} \mathrm{~g} / \mathrm{yr}$. Approximately $2 / 3$ of this is removed by rainfall and the rest by dry fallout (Table 24 ). The $30 \times 10^{14} \mathrm{~g}$ sea salt/yr removal rate determined is higher by a factor of 3 than the estimates made by Eriksson (1959) and is approximately one third the value obtained by Blanchard (1963) (Table 24).

3. Significance of Atmospheric Removal of Sea Salt Over the Coast of Rhode Island

If we compare the mean rate of $\mathrm{Na}$ wet and dry removal on the coast of Rhode Island for all sampling conditions with those for the marine environment (i.e. "marine" samples only) (Table 24), it appears that the amounts of sea salt deposited by rainfall and dry fallout per unit area on the coast of Rhode Island is approximately 
Table 24. Geochemistry of Cyclic Sea Salt

$\mathrm{Na}$ and $\mathrm{Mg}$

Location Mean Rate of Mean Rate of Wet Removal
Dry fallout Wet (rain) gx10-12/ $\mathrm{cm}^{2} \mathrm{sec}$ Removal $\mathrm{g} \times 10^{-12} / \mathrm{cm}^{2} \mathrm{sec}$
Estimated Reference Global

Removal

Rate(sea

salt) gx1014/yr

$\begin{array}{llll}\text { "Land" (R.I.) } & 0.26(\mathrm{Na}) & 2.45(\mathrm{Na}) & 9 \\ \text { "Marine" (R.I.) } & 3.30 \pm 1.86(\mathrm{Na}) & 5.1 \pm 2.4(\mathrm{Na}) & 1.5 \pm 1.1 \\ & 0.57 \pm 0.37(\mathrm{Mg}) & 0.76 \pm 0.44(\mathrm{Mg}) & 1.3 \pm 1.2\end{array}$

This work (1978)
All Samples (R.I.)
$1.5 \pm 1.6(\mathrm{Na})$
$2.0 \pm 1.4$
$(\mathrm{Na})$
$1.3 \pm 1.7$
$0.36 \pm 0.22(\mathrm{Mg})$
$0.40 \pm 0.21(\mathrm{Mg}) \quad 1.1 \pm 0.9$

\section{Sea Salt!}

"Marine" (R.I.) $\quad 11 \pm 6$

5.5

Florida, Caribbean

Hawai i*

Hawai $j$ *

Continents

Continents (R.I.)
5.1

9.6

$\sim 2$

8.0

9 $\sim 1.5$

$\sim 1$

5.5

100
10

3

30

This work (1978)

Eriksson (1959)

Blanchard (1963)

Livingston

(1963)

2.2 This work (1978)

* calculated for the open ocean

! sea salt calculated from $\mathrm{Na}$ by multiplying by 3.25 
$40 \%$ as much as the amounts, per unit area, removed over the ocean.

4. Atmospheric Removal of $\mathrm{Na}$ and Mg Over Land

The $\mathrm{Na}$ and $\mathrm{Mg}$ analysed in "land" samples collected in coastal Rhode Island are essentially of crustal origin as shown by their $\mathrm{Mg} / \mathrm{Na}$ ratios discussed earlier. Although the wind direction was off land during the collection of these samples it is possible that a fraction of the $\mathrm{Na}$ and $\mathrm{Mg}$ in these samples originated in the sea. In this respect these samples resemble the aerosol at inland and continental environments, where a small fraction of the aerosol $\mathrm{Na}$ and $\mathrm{Mg}$ is of oceanic origin, and the main bulk originated in the earth's crust. This small fraction of sea salt particles reaching mid-continent area are usually of smaller size and have longer residence times than the salt particles over the ocean.

Taking all this into consideration one can attempt to estimate tentatively the yearly removal rate of $\mathrm{Na}$ and $\mathrm{Mg}$ over the continents. The rate of dry and wet removal of $\mathrm{Na}$ over land is given in Table 24 . The rate of $\mathrm{Na}$ wet removal was calculated from a mean "land" rain concentration of $1.03 \mathrm{mg} / \mathrm{l}$ and an annual rain depth of $75 \mathrm{~cm}$ (Baumgartner and Reichel, 1975). If we compare these rates of removal to the rates of removal over the oceans and take into consideration the fact that 7 and area constitute only $25 \%$ of the earth's surface, it seems that only $2 \%$ of the total sea salt removed by dry fallout over the earth, is deposited on land and $12 \%$ of the total sea salt removed by rainfall is deposited over land. The total amount of salt, calculated from the $\mathrm{Na}$ data removed over land would be $22.2 \times 10^{14} \mathrm{~g} / \mathrm{yr}$. This is $28 \%$ of the yearly global removal rate. Since a fraction of the $\mathrm{Na}$ and $\mathrm{Mg}$ in "land" samples is of crustal origin, and because the Rhode Island 
coast is not really representative of mid-continent areas, even when the surface winds are not off the ocean, this estimate of $2.2 \times 10^{14} \mathrm{~g} / \mathrm{yr}$ represents a maximum value for the amount of sea salt removed annually over land. Livingstone (1963) calculated that the annual global input of cyclic salt $\mathrm{Na}$ from river runoff into the ocean is approximately $10^{14} \mathrm{~g} / \mathrm{yr}$, equivalent to a total salt content of $23 \times 10^{14} \mathrm{~g} / \mathrm{yr}$, near the estimate above. 


\section{CONCLUSIONS}

The rates and processes of removal of atmospheric sea salt from the marine and Rhode Island coastal atmosphere to the earth surface have been investigated. Samples collected at a Rhode Island coastal site appear to represent 3 meteorologically different subenvironments depending on the surface wind direction during sampling. These 3 subenvironments, which when superimposed represent the coastal environment of Rhode Island have been designated "marine", "land", and "mixed", the latter a mixture of the first two.

Dry fallout, rainfall and atmospheric particulate samples collected in this study were analysed for $\mathrm{Na}$ and $\mathrm{Mg}$ using atomic absorption spectrophotometry. The rate of dry fallout and wet (rain) removal of atmospheric sea salt from the coastal Rhode Island "marine" subenvironment, showed a direct relationship with wind speed. Also the rate of $\mathrm{Na}$ dry fallout for samples collected while the wind was off land appears to be dependent on the magnitude of wind speed. Dry fallout samples collected aboard R/VTrident over the North West Atlantic Ocean gave $\mathrm{Na}$ and $\mathrm{Mg}$ rates of dry removal comparable to the values obtained from "marine" samples collected at the coastal R.I. site. Dry deposition velocities for particulate $\mathrm{Na}$ and $\mathrm{Mg}$, calculated from samples collected on the Rhode Island coast, were $2.4 \pm 1.6 \mathrm{~cm} / \mathrm{sec}$ for $\mathrm{Na}$ and $3.0 \pm 7.6 \mathrm{~cm} / \mathrm{sec}$ for Mg.

The $\mathrm{Na}$ or Mg concentration in "marine" and "mixed" rains showed an inverse logarithmic relationship with the rain depth in $\mathrm{cm}$. Comparison between the mean $\mathrm{Mg} / \mathrm{Na}$ ratios in dry fallout samples with rainfall samples collected in the 3 subenvironments of coastal R.I. indicate that rainfall more efficiently removes sea salt aerosols relative to 
crustal particles.

Rainfall and dry deposition are the major processes for global atmospheric removal of cyclic sea salt. The annual global removal rate of a tmospheric sea salt was estimated as $\sim 3.0 \times 10^{15} \mathrm{~g} / \mathrm{yr}$, higher by a factor of 3 than an estimate made by Eriksson (1959), and Tower by a factor of 3 than the value calculated by Blanchard (1963). It is estimated that $\sim 2 / 3$ of the total cyclic sea salt is removed by rainfall and the rest by dry deposition. Less than $2.2 \times 10^{14} \mathrm{~g} / \mathrm{yr}$ of cyclic sea salt ( $\sim 7 \%$ of the total) is removed over 1 and by rainfall and dry deposition. Rainfall is 9 times as important as dry deposition over land. 


\section{REFERENCES}

Baumgartner, A. and Reichel, E. 1975. The world water balance. New

York: Elsevier Scientific Publishing Company, 179 pp.

Blanchard, D.C., Woodcock, A.H. 1957. Bubble formation and modifi-

cation in the sea and its meteorological significance. Tellus 9: 145-58.

Blanchard, D.C. 1963. Electrification of the atmosphere by particles from bubbles in the sea. Progress in Oceanography. Vol. 1. 0xford, England: Pergamon. 71-202.

Boyce, S.G. 1951. Source of atmospheric salt. Science 113: 620-1. Buat-Menard, P., Morel1i, J., Chesselet, R. 1974. Water soluble

elements in atmospheric particulate matter over tropical and equatorial Atlantic. ‥ Rech. Atmos. 8: 661-73.

Cawse, P.A. and Peirson, D.H. 1972. An analytical study of trace

elements in the atmospheric environment. U.K. Atomic Energy Authority, Harwell. AERE-R 7134, $26 \mathrm{pp}$.

Cawse, P.A. 1974. A survey of atmospheric trace elements in the

U.S. (1972-73). U. K. At. Energy Authority, Harwell. AERE-R7669,

$84 \mathrm{pp}$.

Chamberlain, A.C. 1960. Aspects of the deposition of radioactive and other gases and particles. Int. J.Air Poll. 3: 63-88.

Chesselet, R., Morelli, J., Buat-Menard, P. 1972. Variation in ionic

ratios between reference sea water and marine aerosols. $\underline{\mathrm{J}}$. Geophys. Res. 77: 5116-31.

Dams, R., Rahn, K.A., Winchester, J.W. 1972. Evaluation of filter materials and impaction surfaces for nondestructive neutron activation analys is of aerosols. Environ. Sci. Technol. 6: 447-448. 
Duce, R.A., et al. 1969. Variation of sodium and chloride concentrations with rainfall intensity in Hawai ian trade wind showers. Pacific Science XXIII: 483-495.

Duce, R.A. and Hoffman, E.J. 1976. Chemical fractionation at the Air/Sea interface. Annual Review of Earth and Planetary Sciences 4: $187-228$.

Eriksson, E. 1952. Composition of atmospheric precipitation; sulphur, chloride, iodine compounds. Part II. Tellus 4: 280-303. Eriksson, E. 1959. The yearly circulation of chloride and sulphur in nature: meteorological, geochemical, and pedological implications. Part I, Tellus 11: 375-403.

Fisher, R.A. 1958. Statistical methods for research workers. New York: Hafner Publication Company Incorporated, 356 pp. Fries, H.S.J. 1923. Substances dissolved in rain and snow. Chem. News. London. 126: 113, abstracted in Mather, J.R. 1960. Annotated bibliography on precipitation chemistry. Publication in Climatology XIII: 178.

Galloway, J.N., Likens, G.E. 1976. Calibration of collection procedures for the determination of precipitation chemistry. Reprinted from: Proceedings of the First International Symposium on Acid Precipitation and Forest Ecosystems, USDA Forest Service General Technical Report NE-23.

Georgi i, H.W. 1960. Untersuchungen uber atmospharische Spurenstoffe und ihre Bedertung fur die Chemie der Niederschlage. Geofis. Pura e App1. 47: 155-171, cited by Junge, C.E. 1963. Air Chemistry and Radioactivity. New York: Academic Press. 4: 289-351. 
Girenko, A. Kh. 1959. Hydrochemical conditions of atmospheric precipitation as observed in the Rostov region. Gidrophim. Materialy 28: 112-19 (Russ), abstracted in Chemical Abstracts 1961. 55: 9993e.

Hoffman, E.J. 1969. Lead in pollution aerosols from Oahu, Hawaii. M.S. thesis. Univ. of Hawaii, Hawaii.

Hoffman, E.J., Hoffman, G.L., Fletcher, I.S., Duce, R.A. 1977. Further consideration of alkali and alkaline earth geochemistry of marine aerosols: results of a study of marine aerosols collected on Bermuda. Atmospheric Environment. 11: 373-377. Hoffman, G.L. 1971. Particulate trace metals in the Hawaiian marine atmosphere. Ph.D. thesis. Univ. of Hawai, Hawaii. Hoffman, G.L. and Duce, R.A. 1972. Consideration of the chemical fractionation of alkali and alkaline earth metals in the Hawailan marine atmosphere. ․․ Geophys. Res. 77: 5161-5169.

Junge, C.E. 1963. Air Chemistry and Radioactivity. New York:

Academic Press, 382 pp.

Kashtanov, S.G. 1968. Chemical composition of atmospheric precipitation in Kazan (1964-1966). Uch. Zap., Kazan. Gos. Univ. 128: 79- 82 (Russ.), abstracted in Chemical Abstracts 1970. 72 : $5286 u$.

Kientzler, C.F., Arons, A.B., Blanchard, D.C., Woodcock, A.H. 1954. Photographic investigation of the projection of droplets by bubbles. bursting at a water surface. Tellus. 6: 1-7. 
Knight, N. 1920. Substances dissolved in rain and snow. Chem. News. London. 121: 13-14. Abstracted in Mather, J.R. 1960. Annotated bibliography on precipitation chemistry. Publication in Climatology XIII : 116 .

Knight, N. 1924. Substances in rain and snow. Iowa Acad. Sci. Proc., 31: 325-326. abstracted in Mather, J.R. 1960. Annotated bibliography on precipitation chemistry. Publication in Climatology XIII: 119.

Komabayasi, M., 1962. Enrichment of inorganic ions with increasing atomic weight in aerosol, rainwater, and snow in comparison with sea water. J. Meteorol. Soc. Jpn 40: 25-38.

Koyama, T., Sugawara, K. 1953. Separation of the components of atmospheric salt and their distribution. Bull. Chem. Soc. Jpn. 26: 123-26.

Kreh1. et a1. 1935. Analysis of rains and snows at Mount Vernon, Iowa, 1934-1935. Mon. Wea. Rev, U.S. 63: 162-163. Abstracted in Mather, J.R. 1960. Annotated bibliography on precipitation chemistry. Publication in Climatology XIII: 123.

Krivopalova, Z.F. 1971. Chemical composition of atmospheric precipitation in the Troitsk region. Sb. Nauch. Tr., Magnitogorsh. Gornmet. Instit. 87: 49-50 [Russ.], abstracted in Chemical Abstracts. 1975. 80: 147748K.

Kynett, L. et a7. 1929. Chemical composition of rains and snows at Mount Vernon, Iowa. Mon. Wea. Rev., U.S., 57: 461, abstracted in Mather, J.R. 1960. Annotated bibliography on precipitation chemistry. Publication in Climatology XIII: 121. 
Livingstone, D.A. 1963. Chemical composition of rivers and lakes.

\section{U.S. Geol. Survey Prof. Paper 440-G 1-64:}

Madgwick, H.A.I. and Ovington, J.D. 1959. The chemical composition of precipitation in adjacent forests and open plots. Forestry 32: 14-22, cited by Junge, C.E. 1963. Air chemistry and Radio activity. New York: Academic Press. 4: 289-351.

Martins,C.S., et al.1973."Chemistry of aerosols, cloud droplets, and rain

in the Puerto-Rican marine atmosphere", ‥ Geophys. Res. 78: 949-57.

Mason, B.J. 1957. The oceans as a source of cloud-forming nuclei Geofisica Pura e Applicata 36: 148-55.

Mather, J.R. 1960. Annotated bibliography on precipitation chemistry. Publication in Climatology XIII: 97-154.

Medwin, H. 1970. In situ acoustic measurements of bubble population in coastal ocean waters. J. Geophys. Res. 75: 599-611.

Medwin, H. 1977. In situ acoustic measurements of microbubbles at sea. J. Geophys. Res. 82: $971-976$.

Oddie, B.C.V. 1960. The variation in composition of sea salt nuclei with mode of formation Quart. ‥ Roy. Meteorol. Soc. 86: 549-51. Palmieri, Francesco. 1966. Saline constituents of rain water for the meteorological year 1964. Ann. Fac. Sci. Agrar. Univ. Studi Napoli Portici. 30: 479-94 (Ital)., abstracted in Chemical Abstracts 1966. 63: 1959e.

Pytkowicz, R.M. and Kester, D.R. 1971. The physical chemistry of sea water. Oceanogr. Mar. Biol. Ann. Rev. 9: 11-60. 
Riley and Chester, 1971. Introduction to marine chemistry. New York: Academic Press, 465 pp.

Shaffer, S. 1921. Substances dissolved in rain and snow. Mon. Wea.

Rev. U.S. 49: 404-405, abstracted in Mather, J.R. 1960.

Annotated bibliography on precipitation chemistry. Publication in CTimatology XIII: 117.

Stafford, R.G., and Ettinger, H.J. 1972. Filter efficiency as a function of particle size and velocity. Atmos. Environ. 6: 353-368. Sugawara, K., Oana, S., Koyama, T. 1949. Separation of the components of atmospheric salt and their distribution. Bull. Chem. Soc. Jpn. 22: 47-52.

Trieschmann, J.E. 1919. "Nitrogen and other compounds in rain and snow". Chem. News. London 119: 49, abstracted in Mather, J.R. 1960. Annotated bibliography on precipitation chemistry. Publications in Climatology XIII: 116.

Tsunogai, S. 1975. Sea salt particles transported to the land. Tellus XXVII: $51-58$.

Turner, J.S. 1955. The salinity of rainfall as a function of drop

size. Quart. J. Roy. Meteorol. Soc. 81: 418-429. Woeh7k, J.H. 1923. Nitrogen and other substances in rain and snow. Chem. News, London 127: 30. Abstracted in Mather, J.R. 1960. Annotated bibliography on precipitation chemistry. Publications in Climatology XIII: 119.

Woodcock, A.H. 1953. Salt nuclei in marine air as a function of altitude and wind force.. ․ Meteorol. 10: 363-71.

Yushkevich, I.A. et a1. 1971. Nitrogen, phosphorous and potassium entrance into soil with precipitation under the condition of Belorussia. Pochvovedenie 11: 70-4. [Russ.], abstraced in Chemical Abstracts 1972. 76: $58278 \mathrm{~g}$. 
Zhavoronkina, T.K. 1953. Chemical composition of atmospheric precipitation. Meteorologiya i Gidrologia 9: 22-4 (Russ.), abstracted in Chemical Abstracts 1960. 54: 19053C.

Zverev, V.P. et a1. 1973. Role of atmospheric precipitation in circulation of chemical elements between atmosphere, hydrosphere and lithosphere. Proc. Symp. Hydrogeochemistry Biogeochem. 1973. Washington. D.C.: Clarke Co. 1: 673-20., abstracted in Chenica? Abstracts 1973. 79: $33824 \mathrm{f}$ 